\title{
Water-Quality Assessment of the Puget Sound Basin, Washington--Summary of Stream Biological Data Through 1995
}

By Robert W. Black and Mariabeth Silkey

\section{U.S. GEOLOGICAL SURVEY}

Water-Resources Investigations Report 97-4164 


\section{U.S. DEPARTMENT OF THE INTERIOR \\ BRUCE BABBITT, Secretary}

U.S. GEOLOGICAL SURVEY

Mark Schaefer, Acting Director

Any use of trade, product, or firm names is for descriptive purposes only and does not imply endorsement by the U.S. Geological Survey.

For additional information write to:

\section{District Chief}

U.S. Geological Survey

1201 Pacific Avenue, Suite 600

Tacoma, Washington 98402
Copies of this report may be purchased from:

\author{
U.S. Geological Survey \\ Branch of Information Services \\ Box 25286 \\ Denver, Colorado 80225
}

Information regarding the National Water-Quality Assessment (NAWQA) Program is available on the Internet via the World Wide Web. You may connect to the NAWQA Home Page using the Universal Resource Locator (URL) at:

<URL:http://wwwrvares.er.usgs.gov/nawqa/nawqa_home.html> 


\section{FOREWORD}

The mission of the U.S. Geological Survey (USGS) is to assess the quantity and quality of the earth resources of the Nation and to provide information that will assist resource managers and policymakers at Federal, State, and local levels in making sound decisions. Assessment of water-quality conditions and trends is an important part of this overall mission.

One of the greatest challenges faced by waterresources scientists is acquiring reliable information that will guide the use and protection of the Nation's water resources. That challenge is being addressed by Federal, State, interstate, and local water-resource agencies and by many academic institutions. These organizations are collecting water-quality data for a host of purposes that include: compliance with permits and water-supply standards; development of remediation plans for a specific contamination problem; operational decisions on industrial, wastewater, or water-supply facilities; and research on factors that affect water quality. An additional need for water-quality information is to provide a basis on which regional and national-level policy decisions can be based. Wise decisions must be based on sound information. As a society we need to know whether certain types of water-quality problems are isolated or ubiquitous, whether there are significant differences in conditions among regions, whether the conditions are changing over time, and why these conditions change from place to place and over time. The information can be used to help determine the efficacy of existing water-quality policies and to help analysts determine the need for and likely consequences of new policies.

To address these needs, the Congress appropriated funds in 1986 for the USGS to begin a pilot program in seven project areas to develop and refine the National Water-Quality Assessment (NAWQA) Program. In 1991, the USGS began full implementation of the program. The NAWQA Program builds upon an existing base of water-quality studies of the USGS, as well as those of other Federal, State, and local agencies. The objectives of the NAWQA Program are to:
-Describe current water-quality conditions for a large part of the Nation's freshwater streams, rivers, and aquifers.

-Describe how water quality is changing over time.

-Improve understanding of the primary natural and human factors that affect water-quality conditions.

This information will help support the development and evaluation of management, regulatory, and monitoring decisions by other Federal, State, and local agencies to protect, use, and enhance water resources.

The goals of the NAWQA Program are being achieved through ongoing and proposed investigations of 60 of the Nation's most important river basins and aquifer systems, which are referred to as study units. These study units are distributed throughout the Nation and cover a diversity of hydrogeologic settings. More than two-thirds of the Nation's freshwater use occurs within the 60 study units and more than two-thirds of the people served by public water-supply systems live within their boundaries.

National synthesis of data analysis, based on aggregation of comparable information obtained from the study units, is a major component of the program. This effort focuses on selected water-quality topics using nationally consistent information. Comparative studies will explain differences and similarities in observed water-quality conditions among study areas and will identify changes and trends and their causes. The first topics addressed by the national synthesis are pesticides, nutrients, volatile organic compounds, and aquatic biology. Discussions on these and other waterquality topics will be published in periodic summaries of the quality of the Nation's ground and surface water as the information becomes available.

This report is an element of the comprehensive body of information developed as part of the NAWQA Program. The program depends heavily on the advice, cooperation, and information from many Federal, State, interstate, Tribal, and local agencies and the public. The assistance and suggestions of all are greatly appreciated.

Robert M. Hirsch Chief Hydrologist 


\section{CONTENTS}

Abstract-- 1

Introduction --..-.-.--

Purpose and scope---

Acknowledgments ---

Rationale for evaluating aquatic biological data --

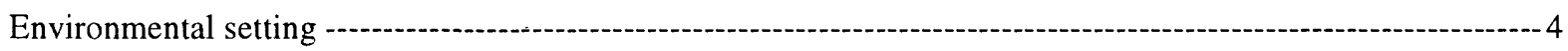

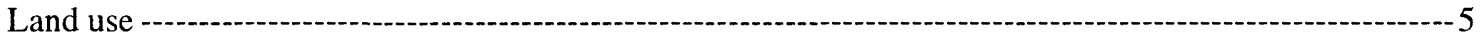

Ecoregions ---

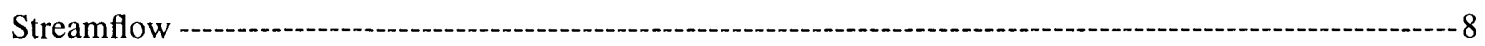

Stream geomorphology -

Status and trends in aquatic biota - - 10

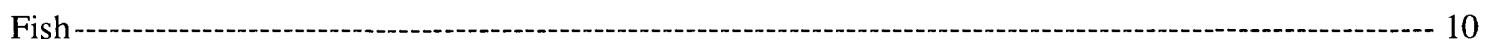

Aquatic benthic macroinvertebrates -

Status and trends in aquatic habitat -

Status and trends of contaminants in fish tissue-- 30

Trace elements --- 32

Synthetic organic compounds -- 36

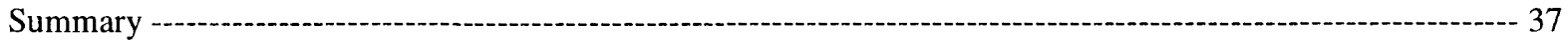

Selected references--- 41

Appendix A.--Summary of trace element concentrations in tissue of fish collected by various agencies from selected sites in the Puget Sound Basin, 1980-1984-- 60

Appendix B.--Summary of synthetic organic compound concentrations in tissue of fish collected by various agencies from selected sites in the Puget Sound Basin, 1980-1992 -.--o- 63

Appendix C.--Sources of aquatic biological data for the Puget Sound Basin---o-a- 68

\section{FIGURES}

1. Map showing the location of Puget Sound Basin NAWQA study unit--o-

2. Map showing generalized land use and physiographic divisions of the Puget Sound Basin ------------6

3. Map showing ecoregions of the Puget Sound Basin -

4. Graph showing salmon and steelhead stock status in the Puget Sound Basin -

5. Graph showing salmon and steelhead stocked in Puget Sound Basin drainages by species, 1981-94 --- 17

6. Maps showing status of salmon and anadromous trout in Washington by species -.- 19

7. Graphs showing the relationship between pieces of large woody debris and stream width, by Puget Sound Basin ecoregion--- 26

8. Graph showing pool frequency, by river basin -

9. Graph showing percentage of times that each human or natural disturbance was cited as a potential cause of fish stock declines--

10. Map showing location of dams and ecoregions in the Puget Sound Basin -

11. Graph showing average minimum, mean, and maximum stream temperature for July 15 to August 15, 1988, for selected sites within the Puget Sound Basin---

12. Map showing fish tissue collection sites in Puget Sound Basin streams - -

13. Graphs showing summary of trace element concentrations in the tissue of fish collected by various agencies from selected sites in the Puget Sound Basin, 1980-84 - 


\section{TABLES}

1. Fish species found in streams in the Puget Sound Basin

2. Status of salmon and steelhead stocks, by river drainage

3. Macroinvertebrates collected from Puget Sound Basin streams, 1977-1994

4. Geometric mean and maximum concentrations of trace elements in fish tissues collected for the U.S. Fish and Wildlife Service National Contaminant Biomonitoring Program, 1980-81 and 1984

5. Geometric mean and maximum concentrations of synthetic organic compounds in fish tissues collected for the U.S. Fish and Wildlife Service National Contaminant

Biomonitoring Program, 1980-81 and 1984

6. Summary of elevated synthetic organic compound concentrations in tissue of fish collected by various agencies from selected sites in the Puget Sound Basin, 1980-92 


\title{
Water-Quality Assessment of the Puget Sound Basin, Washington--Summary of Stream Biological Data
}

\section{Through 1995}

\author{
By Robert W. Black and Mariabeth Silkey
}

\begin{abstract}
The Puget Sound Basin in the State of Washington is one of 15 water-quality study units started in 1994 under the National Water-Quality Assessment Program. As part of the initial phase of the study, current (1995) and historical aquatic biological conditions of the streams of the study basin were summarized, and the natural and anthropogenic factors affecting aquatic organisms within the basin were evaluated to provide a framework for developing study plans and evaluating current and future waterquality trends.
\end{abstract}

The Puget Sound Basin encompasses a 35,224square-kilometer area that drains into Puget Sound and adjacent waters. It is dominated by forest ( 75 percent of basin), urban (11 percent of basin) and agricultural (6 percent of basin) land uses. Each of these land uses have had an effect on aquatic biological resources within the basin. Within the basin, cold-water species of fish represent a significant economic and cultural resource. Of the 46 species and subspecies of fish found in the basin, 11 are migratory (anadromous), 33 are native and 5 are candidates for listing as threatened or endangered. Seven species or subspecies of native migratory salmon and trout are found in the basin and have exhibited declines in their populations. Much less is known about the remaining species of fish found in the basin. Aquatic invertebrates can also be used to evaluate water-quality conditions. More than 165 genera or species of aquatic invertebrates have been identified in the basin. One of these species, the Fender's soliperlan stonefly (Soliperla fenderi) is a Washington species of special $\mathrm{c}$ ncern and a federal candidate for listing under the Endangered Species Act. To date, a limited number of studies have used aquatic invertebrates to evaluate waterquality conditions within the basin. One such study identified the negative effects of urbanization on stream health.

Aquatic habitat conditions within the basin have been altered by current and historical land uses. Channelization, sedimentation, and alterations in vegetation along channel margins have all affected water-quality and biological resources. While many habitat studies have been done, few basin-wide summaries of these data exist. An evaluation of a number of habitat surveys indicates that the abundance of in-stream large, woody debris is limited throughout the basin when compared with streams draining old-growth forests, and the number of pools in the streams draining U.S. Forest Service lands are well below historical levels.

The availability of data on freshwater fish or invertebrate tissue samples analyzed for trace elements and synthetic organic compounds is limited in the Puget Sound Basin. Only 11 freshwater sites were identified in which fish tissue samples were collected between 1980 and 1996. The fish sampled included game fish and bottom fish. Generally, cadmium, copper, and lead concentrations in fish tissue were above the national geometric mean concentrations for samples collected as part of the U.S. Fish and Wildlife Service's National Contaminant Biomonitoring Program. At a few sites, cadmium, copper, lead, and mercury concentrations exceeded maximum levels observed in the U.S. Fish and Wildlife Service national study. At one site, levels of mercury in fish tissue exceeded the levels thought to affect fish-eating birds. Levels of synthetic organic compounds found in fish tissues within the basin were generally below the geometric 
means found in the U.S. Fish and Wildlife Service's national study. However, at a few sites, levels of BHC, PCB's, DDT and its breakdown products, and nonachlor were above the national geometric mean. At one location, levels of BHC and PCB were above the guidelines for protection of predatory fish and wildlife.

\section{INTRODUCTION}

The United States Geological Survey's (USGS) National Water-Quality Assessment (NAWQA) Program uses an interdisciplinary approach to evaluate water quality in relation to its chemical, physical, and biological properties in the Nation's rivers and streams. NAWQA offers a standardized protocol that is applied over a wide geographic range to allow regional comparisons of water quality. The Puget Sound Basin is one of 60 study units proposed for investigation as part of this program. The long-term goals of the NAWQA program, which began full implementation in 1991, are to describe the status of and trends in the quality of the Nation's surface and ground water, and to provide a scientific understanding of the major natural and human factors that affect water quality.

The Puget Sound Basin study unit encompasses the $35,224-\mathrm{km}^{2}$ (square-kilometers) area that drains to the Puget Sound and its adjacent waters, including lands that drain to the Strait of Georgia below the Canadian border and to the eastern part of the Strait of Juan de Fuca. The study unit includes the islands, but not the marine waters, of Puget Sound. It encompasses all or part of 13 counties in western Washington, and the headwaters of the Skagit River and parts of the Nooksack River Basin in British Columbia, Canada (fig. 1).

\section{Purpose and Scope}

This report summarizes existing information on aquatic biota and habitats of streams and rivers within the Puget Sound Basin and includes a topical bibliography of relevant sources of information and data, as well as a list of organizations involved in the examination of aquatic organisms and habitat with the Puget Sound Basin. This information serves as an introduction to the freshwater aquatic ecosystem of the basin, and as a first-cut evaluation of existing data. The report will serve as an aid in designing the Puget Sound Basin NAWQA data collection program by helping to identify factors that regionally affect aquatic biota and to identify areas that are in need of additional monitoring. Specifically, the purposes of this report are to

1. Evaluate the status and trends of aquatic biota and communities from information contained in existing basin-wide studies;

2. Summarize existing watershed and in-stream physical conditions that either affect or may affect aquatic biota within the study basin; and

3. Summarize and evaluate existing information on organic and inorganic residues in fish tissue.

As a broad-scale regional assessment, most of the information included in this report is from large-scale multi-watershed or multi-stream investigations. The report contains little information from the many site- or stream-specific studies conducted in the Puget Sound Basin, as the transfer value of this local information for regional inferences is largely unknown. Information on the status and trends of aquatic biota are limited to fish and invertebrates because these groups have been the primary focus of past and existing monitoring efforts. Little information on algal communities in the Puget Sound Basin is available. Similarly, information about the levels of inorganic and organic residues in the tissues of aquatic biota are limited to fish.

\section{Acknowledgments}

Appreciation is extended to Dr. James Karr and Leska Fore at the University of Washington for their valuable comments and input during the preparation of this document. Jim Doyle and Mike Parton of the U.S. Forest Service provided useful information on the status of stream habitat conditions within the National Forest lands. Randy McIntosh and Dave Sommers of the Salmon and Steelhead Habitat Inventory and Assessment Project and Pat Cagney and Fred Goetz of the U.S. Army Corps of Engineers were also helpful in locating stream habitat data. The U.S. Environmental Protection Agency provided the data base necessary for evaluating the status and trend of contaminants in fish tissues. Rob Plotnikoff (Washington Department of Ecology), Bob Brenner (King County Metro), and James Karr and Gerald Kraft (Western Washington University) all provided information on macroinvertebrates. The authors would also like to thank all of the numerous and extremely helpful individuals we 


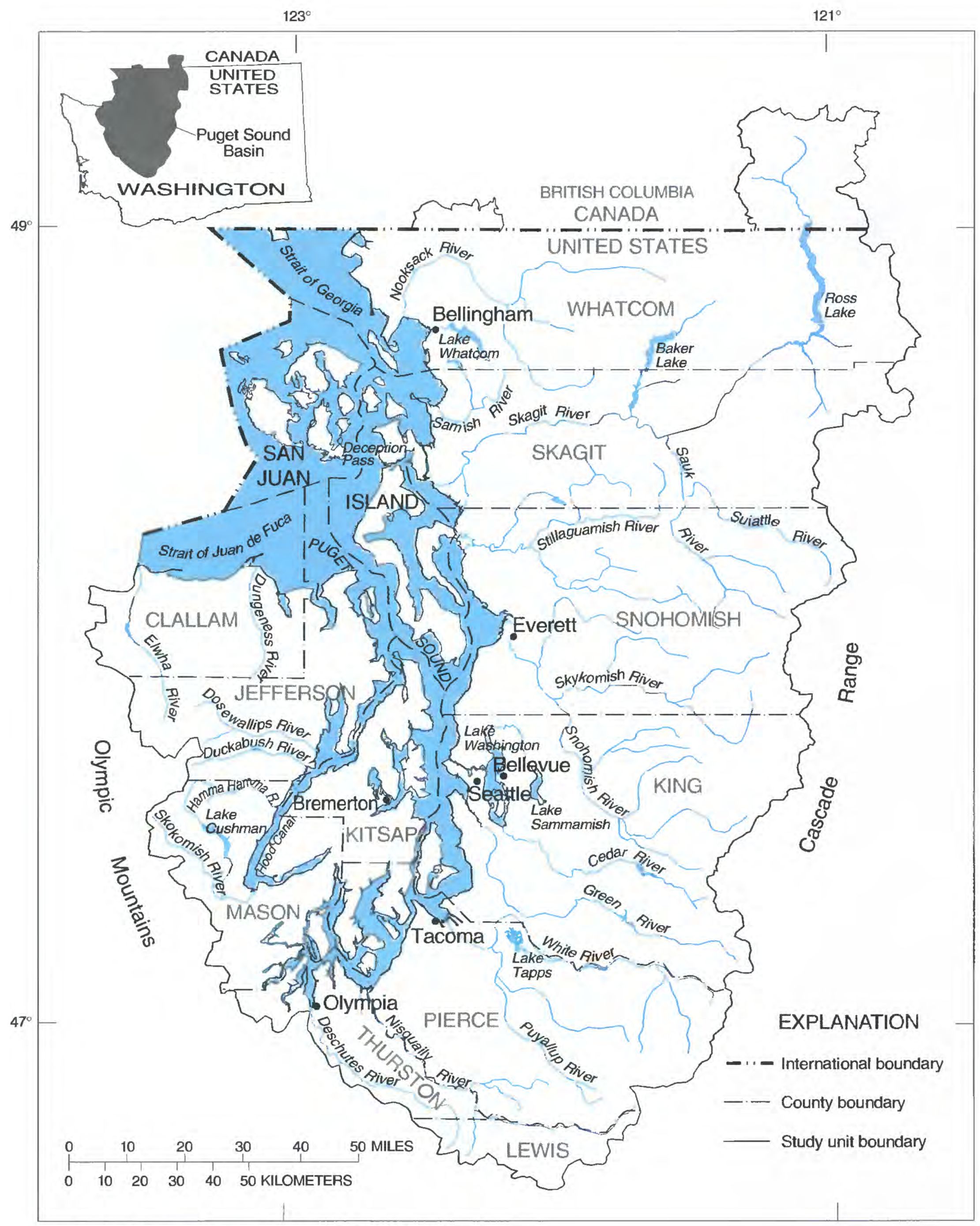

Base from U.S. Geological Survey digital data, 1:2,000,000, 1972 Albers Equal-Area Conic Projection

Stardard parallels $47^{\circ}$ and $49^{\circ}$, central meridian $122^{\circ}$

Figure 1. Location of Puget Sound Basin NAWQA study unit. 
have talked with and who have provided us with data at the Washington Department of Ecology, the Washington Department of Fish and Wildlife, the Wilderness Society, King County Surface Water Management, the Washington Department of Natural Resources, and especially the Northwest Indian Fisheries Commission.

\section{RATIONALE FOR EVALUATING AQUATIC BIOLOGICAL DATA}

The quality of water in the Nations's rivers and streams is important because it can affect human health, the beneficial uses of water for agricultural and industrial purposes, the aesthetic quality of the environment, and the ability of the stream to support aquatic life. The quality of stream water is described by its chemistry, particularly the presence or absence of toxic chemicals; its physical characteristics, which contribute to its suitability as aquatic habitat; and its biologic integrity, which describes the overall health of its aquatic community. Biologic integrity is the sum of the natural biotic and abiotic components found within a landscape and all of the naturally occurring processes that each biotic component relies on. Four useful characteristics for describing the biologic integrity of aquatic systems are the health of individuals, species richness, community composition, and food web structure.

The health of individuals is vital for a reproducing population. The chemical contamination of a water body can have a profound effect on the health of an organism found within it. For example, high levels of some metals have resulted in developmental problems in some aquatic insects (Kosalwat and Knight, 1987; Canfield and others, 1995). Elevated levels of PCB's, as well as heavy metals, in fish have been shown to result in liver tumors (Malins and others, 1980; Malins and others, 1984). More recently, a number of agricultural and industrial chemicals commonly found in surface water have been shown to effect the development of organisms by disrupting the endocrine system (Colborn and others, 1993). By determining levels of contaminants within the tissues of aquatic organisms, scientists can assess the health of aquatic organisms as well as evaluate current and historical waterquality conditions.

Species or taxa richness is the total number of taxa (usually species, though in some cases numbers of a given genus or order) present in a stream. As an undisturbed stream community evolves, natural selection allows more highly specialized taxa to appear. Rare taxa, then, tend to be those with the highest evolutionary investment in "equilibrium" conditions and are the first to disappear when the ecosystem is stressed (Gould, 1989). Thus, biologists commonly measure total taxa richness to discern the health of the overall community.

Shifts in community composition and structure may provide comprehensive evidence of human impacts (Bisson and others, 1992). A community is operationally defined as an interacting group of species. Stream communities are often broken down into fish communities, benthic macroinvertebrate communities, and plant communities, although these three are interdependent. Any degradations to one group will influence the health and status of the other two. Community ecologists may examine the relative abundance of species within a community as an indication of ecosystem health.

A food web is a narrowly defined community in which all relationships are based upon diet. Food web structure can be thought of as the percentage of species in each level of the food chain. Food chains tend to be short, rarely exceeding four links (Pimm, 1982). Increased productivity of an ecosystem does not increase the length of the food chain; rather, increased productivity implies an increase in the number of species, and thus more complex food webs. Food webs represent the flow of energy and nutrients through the ecosystem. A change in the links of a food web could be an indication of anthropogenic impacts.

The information contained within this report includes some of the biotic information suitable for conducting an initial evaluation of water quality on the basis of characteristics described above, particularly species richness, health of individuals and community composition. However, many of these data are of a local or single drainage origin and may not represent conditions within the Puget Sound Basin as a whole. The Puget Sound Basin NAWQA program addresses the four characteristics identified above to describe and assess the status of biological communities in representative environments throughout the Puget Sound Basin. Areas of limited biological data (algae and freshwater aquatic biota health) will be studied and areas of existing information will be added to. The biologic data will be combined with surface and groundwater chemistry to evaluate water quality.

\section{ENVIRONMENTAL SETTING}

The environmental setting of the Puget Sound Basin is described in detail by Staubitz and others (1997). The Puget Sound Basin is composed of three physiographic provinces. The Olympic Mountains in the west and the Cascade Range in the east compose about one-half of the 
study unit land area, and the Puget Sound Lowland, in the middle, composes the rest (fig. 2). Both the Cascade Range and the Olympic Mountains are rugged, largely uninhabited, mountainous terrain with bare rock peaks, steep forested slopes, and deep valleys and canyons.

Most settlement and development has occurred in the Puget Sound Lowland, because of its gentler topography and its proximity to Puget Sound. Land surface elevation seldom exceeds 500-600 feet in the lowland. The Puget Sound Lowland is characterized by a low-relief upland plateau of glacial drift that is incised by broad alluvial valleys of the major rivers and by numerous channels, bays, and inlets of Puget Sound and its adjacent waters. The upland plateau has a surface of rolling hills dotted with small lakes and marshy depressions and has a relief that allows construction of roads and buildings and therefore is generally suitable for development.

\section{Land Use}

Forest, urban, and agriculture are the three principal land uses in the Puget Sound Basin. In 1970, forest covered approximately 6.8 million acres, or 78 percent, of the basin (fig. 2). Urban areas covered approximately 8 percent of the basin and were concentrated along the shores of Puget Sound. Agriculture covered close to 6 percent of the basin and was confined to the lowlands, mostly along the lower reaches of the alluvial river valleys. The remaining land in the Puget Sound Basin was made up of high-elevation tundra ( 2.7 percent), rangeland ( 2.4 percent), perennial snow ( 1.8 percent), wetlands ( 0.8 percent), and barren lands ( 0.4 percent). By the late 1990 's, urban land use is projected to increase to cover as much as 11 percent of the basin, and forest land is expected to decrease to cover only 75 percent of the basin.

\section{Ecoregions}

Ecoregions represent regions of homogeneity in characteristics such as climate, soils and geology, vegetation and physiography (Omernik and Gallant, 1986; Omernik, 1987). Identifying ecoregions organizes environmental-setting information and presents it in a clear and concise fashion. Once identified, ecoregions provide a framework to (1) better compare the similarities and differences of land-water relations, (2) establish waterquality and land-management standards that are in tune with regional patterns of tolerances and resilience to human activities; (3) locate monitoring, demonstration, or reference sites; (4) extrapolate information from existing site specific studies; and (5) predict the effects of changes in land use and pollution controls (Omernik and Gallant, 1986).

Within the Puget Sound Basin, there are four ecoregions (fig. 3): the Coast Range $\left(1,797 \mathrm{~km}^{2}\right)$, the Puget Sound Lowland $\left(16,203 \mathrm{~km}^{2}\right)$, the North Cascades $\left(14,014 \mathrm{~km}^{2}\right)$, and the Cascades $\left(2,994 \mathrm{~km}^{2}\right)$. The Coast Range ecoregion encompasses parts of the Olympic Mountains and represents approximately 5 percent of the basin. This ecoregion is highly dissected by perennial streams having 1.2 to 1.8 kilometers of stream per square kilometer. Elevation ranges from sea level to 450 to 610 meters, with peaks of 1,220 meters. Average annual rainfall ranges from 140 to 510 millimeters, most of which falls during the winter. Woody vegetation within the area is dominated by Douglas fir (Pseudotsuga menziesii), western hemlock (Tsuga heterophylla), sitka spruce (Picea sitchensis), and western red cedar (Thuja plicata). The understory is composed of a continuous mat of shrub and herbaceous vegetation dominated by salmonberry (Rubus spectabilis), rhododendron (Rhododendron macrophyllum), vine maple (Acer circinatum) and evergreen huckleberry (Vaccinium ovatum) (Omernik and Gallant, 1986; McNab and Avers, 1994). The streams within the region support anadromous salmon and trout as well as other coldwater species of fish. Natural disturbances in the area are mostly from winter storms of 25- to 100-year intervals that produce windthrow (uprooted trees) and landslides. Logging and the production of wood products is the major industry within the region.

The Puget Sound Lowland ecoregion is dominated by open hills and table lands of glacial and lacustrine deposits and represents 46 percent of the Puget Sound Basin. Elevations within the region range from sea level up to 760 meters. Rainfall ranges from 35 to 125 millimeters per year. Stream density within the region ranges between 0.6 to 1.2 kilometers per square kilometer. The soils within the Puget Sound Lowland ecoregion were formed by glacial processes under the influence of coniferous forests in the northern range of the ecoregion. In the southern portion of the ecoregion, the soils were formed from igneous and sedimentary parent material, with less glacial activity. The forested areas within the region are dominated by Douglas fir, but also include lodgepole pine (Pinus contorta), and western white pine (Pinus monticola). The riparian zones have cottonwood (Populus spp.), willow (Salix spp.), ash (Fraxinus spp.), and alder (Alnus spp.) (Omernik and Gallant, 1986; McNab and Avers, 1994). The streams within the Puget Sound Lowland ecoregion have numerous species of cold-water fish such as salmon and trout. However, the abundance of 


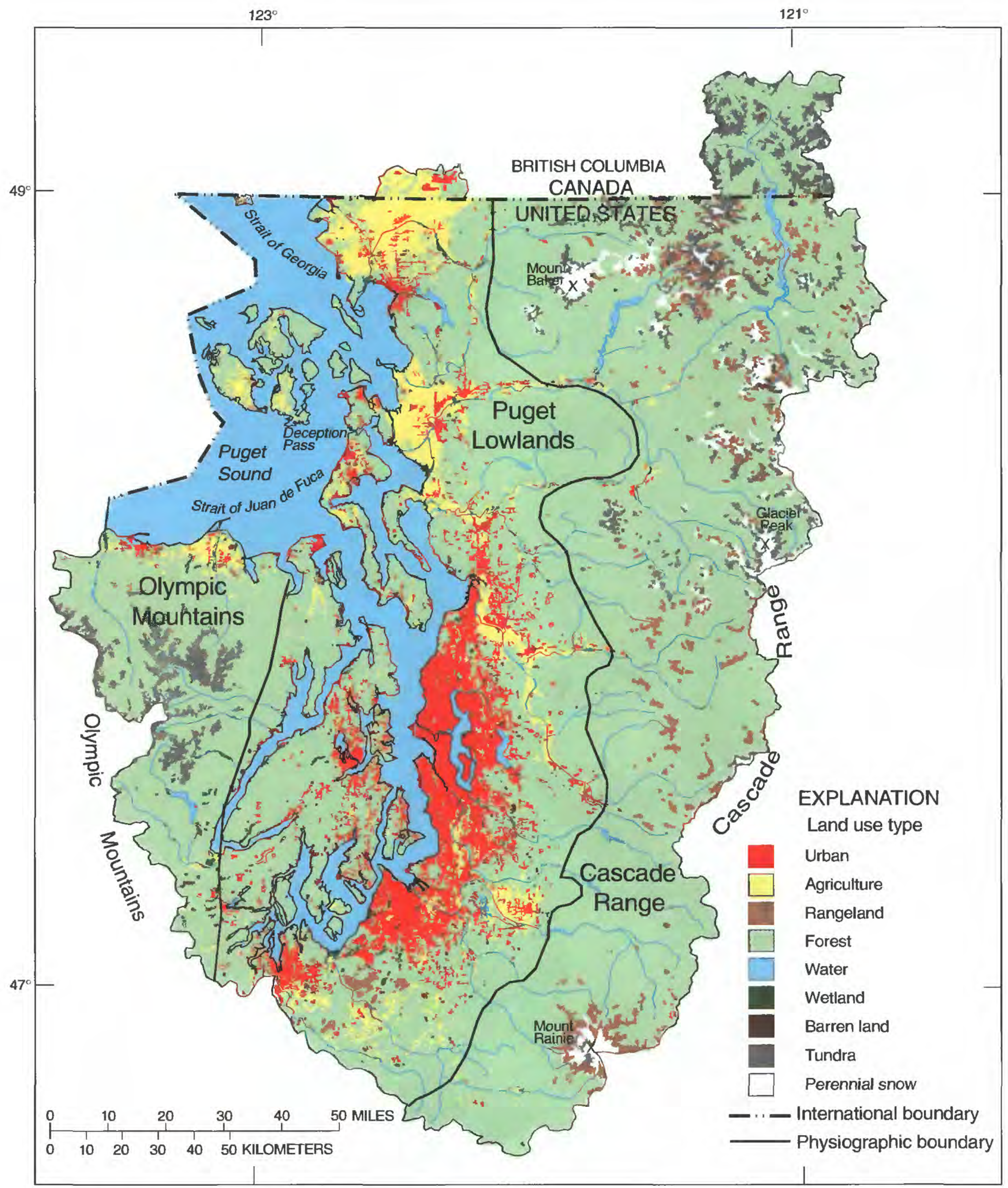

Land use digital data modified from Fegeas and others, 1983.

Figure 2. Generalized land use and physiographic divisions of the Puget Sound Basin. 


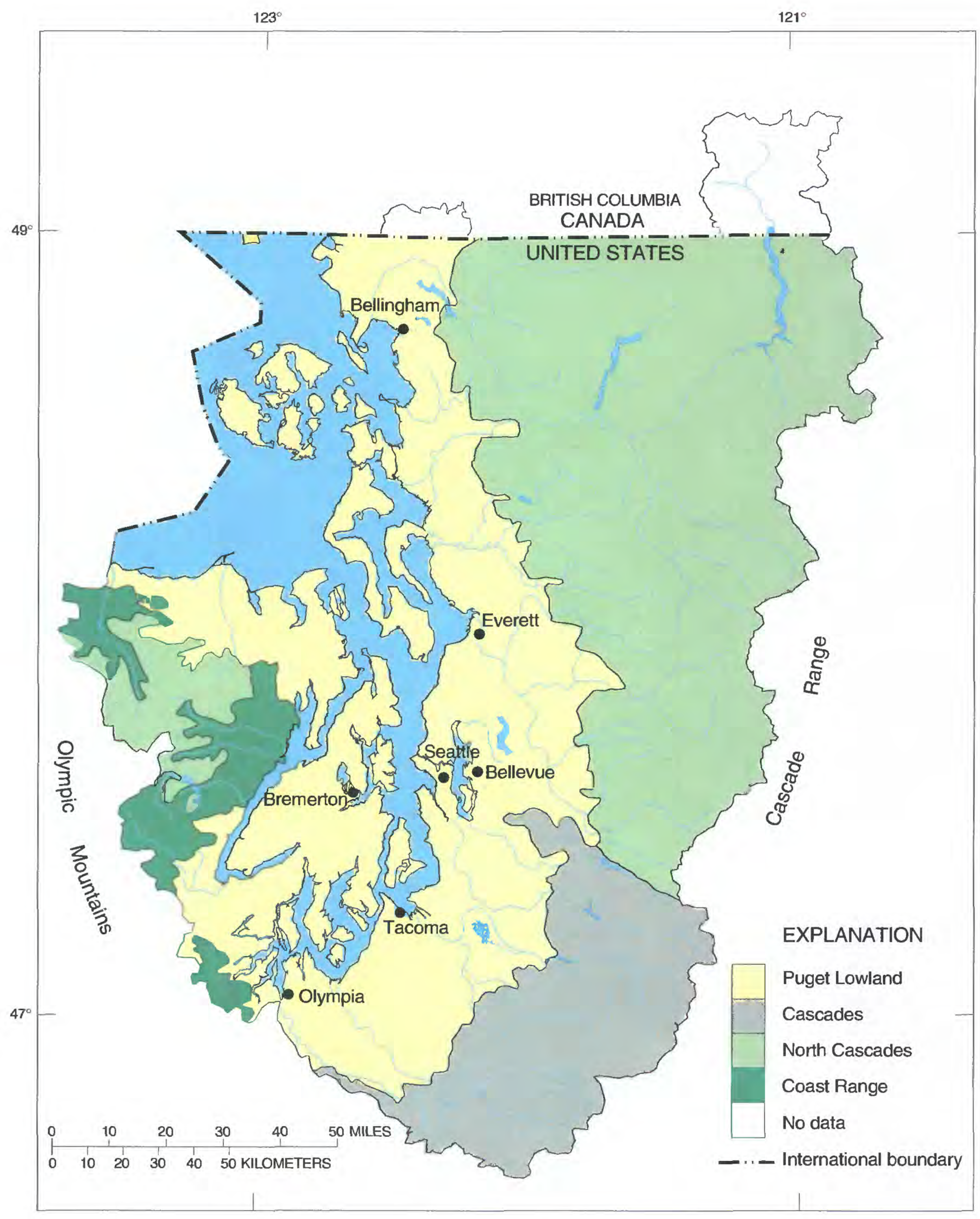

Figure 3. Ecoregions of the Puget Sound Basin. (Modified from Omernik and Gallant, 1986.) 
native salmon and anadromous trout has declined due to overfishing, loss of habitat, urbanization, agricultural activities, logging, and other natural and anthropogenic factors (Nehlsen and others, 1991; Washington State Department of Fish and Wildlife and Western Washington Treaty Indian Tribes, 1994).

The North Cascades ecoregion occupies 40 percent of the Puget Sound Basin. It is geologically dominated by igneous and metamorphic rock and some sedimentary rocks. Topographically, it is irregular and is dominated by peaks and valleys shaped by glacial activity. Elevations within the ecoregion range from near sea level to greater than 3,000 meters, with average rainfall totals between 125 and 250 millimeters. The stream density is between 0.9 and 1.2 kilometers of stream per square kilometer. The ecoregion is dominated by Douglas and silver fir (Abies amabilis), with additional areas of western white pine, western hemlock, and western red cedar (Thuja plicata). Higher elevations contain mountain hemlock (Tsuga mertensiana), subalpine fir (Abies lasiocarpa), whitebark pine (Pinus albicaulis), and Engelmann spruce (Picea engelmannii). Shrub cover is dominated by vine maple, rhododendron, huckleberry, blackberry (Rubus procerus), and Oregon grape (Omernik and Gallant, 1986; McNab and Avers, 1994). The limited alpine meadow areas are vegetated by bent grass, fescue, bluegrass, and sedges. The North Cascades ecoregion is a major timber harvesting area. The ecoregion experiences heavy erosion and sedimentation due to snowmelt and rain-on-snow events, logging, road building, and grazing.

The Cascades ecoregion, to the south, represents 9 percent of the Puget Sound Basin. The vegetation in the Cascades ecoregion is similar to that of the North Cascades ecoregion. Topographically and geologically, the two areas exhibit some differences. The Cascades ecoregion is dominated geologically more by volcanic activity than the North Cascades. The Cascades topography is less rugged and is more plateau-like than the North Cascades, with isolated peaks surrounded by larger alpine meadow areas. The streams in both areas are populated by resident and anadromous trout and salmon. The disturbance regime in both ecoregions is dominated by windthrow and an occasional fire (Omernik and Gallant, 1986; McNab and Avers, 1994).

\section{Streamflow}

The Puget Sound Basin is composed of more than 100 watersheds that drain to Puget Sound and its adjacent waters. These watersheds range in drainage area from
$8,246 \mathrm{~km}^{2}$ to only a few acres. Most of the larger rivers originate in the Olympic Mountains or the Cascade Range and drain high-altitude areas that receive from 125 to more than 510 millimeters of precipitation annually. In the major river basins with headwaters in the mountains, the highest monthly flows generally occur in December and January, in response to increased winter rainfall and in May and June, in response to mountain snowmelt. Lowest flows occur in September at the end of the typically dry summer. Smaller streams draining the lowlands typically have little or no seasonal snowpack within their watershed and receive no spring snowmelt. Flows in lowland streams generally peak in January and February and decrease in the spring as precipitation decreases and water loss from evapotranspiration increases. Lowland streams typically have extended periods of low flow during the summer.

Major floods in the Puget Sound Basin occur almost without exception during the winter months and most commonly during the months of November, December, and January. The floods generally result from intense, warm rains that originate from a southwesterly storm track, and the climatic conditions that cause this storm track may persist over an extended period, causing multiple floods in a given year. These rains alone can cause flooding in the smaller lowland streams, particularly in urban areas that have a proportionately large ( 25 to 75 percent) amount of impervious area (King County Surface Water Management Division, 1987). In the larger river basins with headwaters in the mountains, rainfall can be substantially augmented by melting snow, and the largest floods generally occur when the snowpack extends to the lower altitudes and is thin enough to be melted completely.

\section{Stream Geomorphology}

Streams are commonly grouped into three general geomorphic categories (low, mid, or high order) on the basis of their tributary network, and streams within each category tend to share common characteristics within a given area. Low-order streams are small headwater streams with few tributaries, mid-order streams drain larger watersheds and have a greater number of tributaries, and high-order streams are the largest rivers with the largest watersheds and the most extensive drainage networks.

Low-order streams in the Puget Sound Basin are found primarily in the Cascade Range and Olympic Mountains and secondarily in the Puget Sound Lowland. Low-order mountain streams represent more than 70 percent of the cumulative channel length within the basin and 
are the initial conduits for water, sediment, and organic matter to the larger rivers that discharge to Puget Sound (Benda and others, 1992). These small streams, which typically drain steep, forested mountain slopes, have high gradients (greater than 8 degrees) and are filled with colluvium that is characterized by coarse, unsorted sediments. In their natural state, these streams are subject to occasional landslides from bank failure or debris flows, and they contain substantial amounts of boulders and large organic matter (woody debris) that create well-developed pools and riffles. Their stream banks are well vegetated, their channels are well shaded, and they generally provide good habitat for salmon, trout, and other cold-water fish species.

Low-order streams within the lowlands generally originate in glacially deposited material on the upland plateau and in the foothills of the Cascade Range. Small lakes or wetlands often compose the headwaters of these streams, and as they meander across the broad glacial drift plains and alluvial valleys, these streams are commonly associated with small streamside wetlands (King County Surface Water Management Division, 1987). Many of these lowland streams are low gradient and shallow and do not move as much sediment or organic material as do the headwater mountain streams. In their natural state, low-order lowland streams are in many ways similar to low-order mountain streams in that they have dense riparian vegetation, well-shaded stream channels, an ample supply of woody debris, and well-developed pools and riffles (Montgomery and others, 1995), providing good habitat for numerous fish species.

Mid-order channels within the Puget Sound Basin are found in the lower altitudes of the Cascade Range and Olympic Mountains and in the Puget Sound Lowland. These streams are characterized by moderate to steep gradients (1-6 degrees), substrates ranging from boulders to gravels, and in their natural state, abundant woody debris (Naiman and others, 1992). These mid-order mountain streams are subject to a variety of flow conditions, including large peak storm flows from winter rain-on-snow events and low baseflows following the normally dry summer and fall. This hydrologic regime results in broad, meandering, boulder-strewn channels where the streams are not confined by bedrock or steep valley walls.

Mid-order lowland streams are fed by low-order headwater streams emanating from the upland plateau. As the mid-order streams traverse the edges of the upland plateau, they commonly cut long, deep ravines into the erodible glacial deposits. Within these ravines, the mid-order channels have a relatively high gradient (4-6 degrees) and are subject to periodic landslides, which contribute sediment and woody debris to the stream channel, similar to low-order mountain streams. As these mid-order lowland streams emerge from the ravines, they enter a low-gradient outwash area prior to entering higher-order rivers or Puget Sound. In their natural state, the stream channels in this transition area contain large gravel beds, which constitute excellent salmon and trout spawning habitat (King County Surface Water Management Division, 1987).

High-order streams within the drainage basin occur in the Puget Sound Lowland and are fed primarily by mid-order channels. Typically, low gradients within these channels reduce their ability to transport larger particles. These channels are dominated by finer sediments such as gravel, sand, and silt. Large seasonal discharge events and erodible banks result in rivers that, in their natural state, meander across broad floodplains that have seasonally flooded wetlands. In their lower reaches, these rivers discharge to Puget Sound through broad, flat deltas, where the main channel breaks into sloughs or distributor channels that are surrounded by salt marshes. The heterogenous mixture of side channels and wetlands associated with these high-order streams are ideal spawning habitat and refuge for early life stages of many species of salmon (Scott and Crossman, 1985) and other aquatic organisms.

Prior to European settlement, which began about 150 years ago, stream channels within the Puget Sound Basin were relatively stable and provided plentiful habitat for salmonids and other cold-water fish species. In their natural state, the low- and mid-order streams provided ample shaded cool water, clean spawning gravels, refuge pools formed from woody debris dams, and abundant food sources. The high-order streams and their associated side channels, wetlands, sloughs, and deltas provided migration corridors and development refuges for numerous species. However, timber harvesting and land development has had a profound effect on the physical characteristics of Puget Sound Basin streams and has significantly reduced their habitat value (Bisson and others, 1992).

Riparian vegetation has been widely removed from stream banks in urban, agricultural, and forested areas, reducing the amount of woody debris available to form pools in stream channels. In low- and mid-order lowland streams, the number of pools has been further reduced by removal of woody debris dams for flood control and past fisheries management practices. Clear-cut logging and urbanization have also resulted in increased storm peak flows, stream-bank failures, and landslides in low- and mid-order streams. Spawning gravels have been scoured 
and stream channels have been armored with coarse substrate in high gradient stream reaches and buried by fine sediment transported to lower gradient reaches.

High-order streams have been extensively channelized, and dikes have been built to control flooding of urban and agricultural lands. Surrounding side channels, wetlands, and salt marshes in the floodplains and deltas have been drained, diked, and filled for urban and agricultural land development, and fish passage to influent tributaries has been interrupted by dams, culverts, and other flood control structures. Physical alteration of high-order streams has been greatest in the urbanized central Puget Sound region, where salt marsh losses range up to 74 percent in the Snohomish River delta, 99 percent in the Duwamish River delta, and 100 percent in the Puyallup River delta (Puget Sound Water Quality Authority, 1988).

Combined, these physical changes have resulted in a significant decline in the available spawning and rearing habitat for salmon and other aquatic species. The habitat for as much as 1,200 miles of streams within the Nooksack Basin alone is estimated to be degraded and in need of restoration (Nooksack Salmon Enhancement Association, 1995). Habitat in the main stem of the Cedar River is estimated to have been reduced by approximately 56 percent (King County Surface Water Management Division, 1993). This level of degradation is probably typical of other Puget Sound Basin watersheds as well.

\section{STATUS AND TRENDS IN AQUATIC BIOTA}

The numerous cold-water rivers found throughout the Puget Sound are habitat to aquatic invertebrates and migratory and resident fish typical of the Pacific Northwest. Examination of these aquatic macroinvertebrate and fish communities can play a vital role in the assessment of the biological integrity of streams and can help provide an additional framework for assessing the physical and chemical quality of water within the Puget Sound Basin (Karr, 1981; Rosenberg and Resh, 1993; Plotnikoff, 1994; Fore and others, 1996). With the exception of some runs of salmon, the availability of fish and invertebrate community information within the Puget Sound Basin is limited (Bisson and others, 1992; Mongillo and Hallock, 1995).

\section{Fish}

Most of the fisheries work within the Puget Sound Basin has focused on migratory (anadromous) salmon and trout. These fish species are important culturally, recreationally, and economically to the Pacific Northwest and the Puget Sound Basin. However, the ability to identify the water-quality factors that regionally affect aquatic biota depends on the ability to assess the changes in species richness, species composition, the health of individuals, and food web structure of not only salmon, but resident and non-game fish as well. It is the changes in the resident and non-game fish populations and community structure that potentially represent the best indicator of water-quality change (Karr, 1981). Such an assessment is limited by the current lack of data and the limited number of resident fish species. In addition, the abundance, distribution and role of non-game fish in the structure and function of Puget Sound streams and rivers is poorly understood (Bisson and others, 1992). A recent effort is underway to establish a long-term data base on the distribution of resident non-game fish in the State of Washington (Mongillo and Hallock, 1995).

Within the streams of the Puget Sound Basin, at least 14 families of fish are represented by more than 40 species and subspecies of freshwater riverine fish, including salmon and anadromous trout (table 1) (Washington Department of Wildlife and Bonneville Power Administration, 1992). The bull trout (Salvelinus confluentus), green sturgeon (Acipenser medirostris), Olympic mudminnow (Novumbra hubbsi), Pacific lamprey (Lampetra tridentata) and the river lamprey (Lampetra ayresi) are all candidates for listing as threatened and endangered species. Of the 46 species and subspecies found in the basin, 36 are not anadromous, but some species do move freely between fresh and saltwater. Thirteen of the fish within the basin have been introduced (table 1).

The introduction of non-native exotic fish species has contributed to the decline of certain stocks of native salmon by altering the community composition and food web structure of a number of streams (Bisson and others, 1992). For instance, in Issaquah Creek, a small Puget Lowland stream that drains into Lake Sammamish, introduced smallmouth bass, black crappie, bluegill, pumpkinseed, and brown bullhead prey upon juvenile salmon and trout. Competition and predation from introduced species likely occurs in other Puget Sound Basin streams as well. If the habitat and water quality in the streams and rivers of the Puget Sound Basin become further degraded, exotic species may become more prevalent at the expense of native species. 
Table 1.--Fish species found in streams in the Puget Sound Basin

[ ${ }^{*}$, species found in both fresh and saltwater; Sources: Mongillo and Hallock, 1995; Washington Department of Wildlife and Bonneville Power Administration, 1992; Wydoski and Whitney, 1979]

\begin{tabular}{|c|c|c|c|}
\hline \multicolumn{4}{|l|}{ Order } \\
\hline $\begin{array}{l}\text { Family } \\
\text { Common name }\end{array}$ & Species & $\begin{array}{l}\text { Resident or } \\
\text { anadromous }\end{array}$ & $\begin{array}{l}\text { Native or } \\
\text { introduced }\end{array}$ \\
\hline \multicolumn{4}{|l|}{ Petromyzontiformes } \\
\hline \multicolumn{4}{|l|}{ Petromyzonidae } \\
\hline Pacific lamprey & Lampetra tridentata & anadromous & native \\
\hline river lamprey & Lampetra ayresi & anadromous & native \\
\hline western brook lamprey & Lampetra richardsoni & resident & native \\
\hline \multicolumn{4}{|l|}{ Acipenseriformes } \\
\hline \multicolumn{4}{|l|}{ Acipenseridae } \\
\hline green sturgeon & Acipenser medirostris & resident* & native \\
\hline white sturgeon & Acipenser transmontanus & resident* & native \\
\hline \multicolumn{4}{|l|}{ Clupeiformes } \\
\hline \multicolumn{4}{|l|}{ Culpidae } \\
\hline American shad (herring) & Alosa sapidissima & anadromous & introduced \\
\hline \multicolumn{4}{|l|}{ Cypriniformes } \\
\hline \multicolumn{4}{|l|}{ Catostomidae } \\
\hline largescale sucker & Catostomus macrocheilus & resident & native \\
\hline mountain sucker & Catostomus platyrhynchus & resident & native \\
\hline \multicolumn{4}{|l|}{ Cyprinidae } \\
\hline carp & Cyprinus carpio & resident & introduced \\
\hline longnose dace & Rhinichthys cataractae & resident & native \\
\hline northern squawfish & Ptychoeilus oregonensis & resident & native \\
\hline peamouth & Mylocheilus caurinus & resident & native \\
\hline redside shiner & Richardsonius balteatus & resident & native \\
\hline \multicolumn{4}{|l|}{ Siluriformes } \\
\hline \multicolumn{4}{|l|}{ Ictaluridae } \\
\hline brown bullhead & Ameiurus nebulosus & resident & introduced \\
\hline \multicolumn{4}{|l|}{ Salmoniformes } \\
\hline \multicolumn{4}{|l|}{ Umbridae } \\
\hline Olympic mudminnow & Novumbra hubbsi & resident & native \\
\hline \multicolumn{4}{|l|}{ Osmeridae } \\
\hline eulachon & Thaleichthys pacificus & anadromous & native \\
\hline longfin smelt & Spirinchus thaleichthys & anadromous & native \\
\hline \multicolumn{4}{|l|}{ Salmonidae } \\
\hline Arctic grayling & Thymallus arcticus & resident & introduced \\
\hline Atlantic salmon & Salmo salar & anadromous & introduced \\
\hline brook trout & Salvelinus fontinalis & resident & introduced \\
\hline brown trout & Salmo trutta & resident & introduced \\
\hline bull trout (char) & Salvelinus confluentus & resident & native \\
\hline chinook salmon & Oncorhynchus tshawytscha & anadromous & native \\
\hline chum salmon & Oncorhynchus keta & anadromous & native \\
\hline coho salmon & Oncorhynchus kisutch & anadromous & native \\
\hline cutthroat trout (and coastal) & Oncorhynchus clarki & resident/anadromous & native \\
\hline dolly varden & Salvenius malma & resident & native \\
\hline mountain whitefish & Prosopium williamsoni & resident & native \\
\hline pink salmon & Oncorhynchus gorbuscha & anadromous & native \\
\hline rainbr $N$ trout (and steelhead) & Oncorhynchus mykiss & resident/anadromous & native \\
\hline sockeye (and kokanee) & Oncorhynchus nerka & resident/anadromous & native \\
\hline
\end{tabular}


Table 1.--Fish species found in streams in the Puget Sound Basin--continued

\begin{tabular}{|c|c|c|c|}
\hline $\begin{array}{l}\text { Order } \\
\text { Family } \\
\text { Common name }\end{array}$ & Species & $\begin{array}{l}\text { Resident or } \\
\text { anadromous }\end{array}$ & $\begin{array}{l}\text { Native or } \\
\text { introduced }\end{array}$ \\
\hline \multicolumn{4}{|l|}{ Gasterosteiformes } \\
\hline \multicolumn{4}{|l|}{ Gasterosteidae } \\
\hline \multicolumn{4}{|l|}{ Scorpaeniformes } \\
\hline \multicolumn{4}{|l|}{ Cottidae } \\
\hline coastrange sculpin & Cottus aleuticus & resident & native \\
\hline mottled sculpin & Cottus bairdi & resident & native \\
\hline prickly sculpin & Cottus asper & resident & native \\
\hline Pacific staghorn scuplin & Cottus armatus & resident* & native \\
\hline reticulate sculpin & Cottus perplexus & resident & native \\
\hline shorthead sculpin & Cottus confusus & resident & native \\
\hline torrent scuplin & Cottus rhotheus & resident & native \\
\hline \multicolumn{4}{|l|}{ Perciformes } \\
\hline \multicolumn{3}{|l|}{ Percidae } & introduced \\
\hline \multicolumn{4}{|l|}{ Centrarchidae } \\
\hline black crappie & Pomoxis nigromaculatus & resident & introduced \\
\hline bluegill & Lepomis macrochirus & resident & introduced \\
\hline largemouth bass & Micropterus salmoides & resident & introduced \\
\hline pumpkinseed & Lepomis gibbosus & resident & introduced \\
\hline smallmouth bass & Micropterus dolomieui & resident & introduced \\
\hline \multicolumn{4}{|l|}{ Pleuronectiformes } \\
\hline $\begin{array}{l}\text { Pleuronectidae } \\
\text { starry flounder }\end{array}$ & Platichthys stellatus & resident* & native \\
\hline
\end{tabular}

Although the diversity of fish species within the Puget Sound Basin is limited (Moyle and Herbold, 1987), many unique stocks of anadromous salmon and trout are found throughout the basin. A fish stock refers to "the fish spawning in a particular lake or stream(s) at a particular season, which to a substantial degree do not interbreed with any group spawning in a different place, or in the same place during a different season" (Washington Department of Fish and Wildlife and Western Washington Treaty Indian Tribes, 1994). However, many of these salmon stocks are at serious risk of extinction. A recent analysis has indicated that more than 200 stocks of anadromous salmonids in the western United States are at some level of risk of becoming extinct (Nehlsen and others, 1991). Habitat damage resulting from hydropower development, logging, mining, agriculture, urbanization, overfishing, and competitive interactions with hatchery fish represent the greatest threat to 90 percent of the over 200 stocks of salmon threatened with extinction (Nehlsen and others, 1991; Riddell and Swain, 1991).

The status of salmon and anadromous trout populations within the Puget Sound Basin have been evaluated by a number of sources (Nehlsen and others, 1991; Washington Department of Fish and Wildlife and Western Washington Treaty Indian Tribes, 1993, 1994; The Wilderness Society, 1993). Nehlsen and others (1991) identified the following stocks of salmon that are now extinct within the Puget Sound Basin: Nisqually River chum, Elwha River sockeye, Snohomish River chinook (spring), Duwamish-Green River chinook (spring), Puyallup River chinook (spring), Nisqually River chinook and Chambers Creek chum (summer). Some of the findings presented by Nehlsen and others (1991) have been disputed (Washington Department of Fish and Wildlife and Western Washington Treaty Indian Tribes, 1993). 
An additional evaluation of the current status of salmon and anadromous trout stocks was performed by the Washington State Department of Fish and Wildlife and the Western Washington Treaty Indian Tribes in the Salmon and Steelhead Stock Inventory (SASSI) report (Washington Department of Fish and Wildlife and Western Washington Treaty Indian Tribes, 1993, 1994). The SASSI report rated the status of each of the 33 chinook, 39 chum, 39 coho, 15 pink, and 5 sockeye salmon stocks and 48 steelhead trout stocks within the Puget Sound Basin on the basis of five criteria. These criteria included long-term negative population trends, short-term severe population declines, chronically low stocks, decreases in fitness, and unknown status. These screening criteria were used by State and Tribal fisheries scientists to assign each stock to one of four categories: healthy, depressed, critical, or unknown. A healthy stock of fish exhibits reproductive rates and population levels consistent with the available habitat and within natural variations for that stock. A depressed stock exhibits reproductive rates and population levels below expected values based on available habitat and natural variations in survival rates, but above the level at which permanent damage to the stock is likely. Critical stocks are those in which reproductive rates and population levels are so low that permanent damage to the stock is likely or has already occurred. Stocks identified as unknown have insufficient data on reproductive rates or population levels to address the success or failure of the stock. Of all of the anadromous salmon and trout stocks, the sockeye salmon has the poorest stock status (fig 4).

All of the sockeye salmon stocks within the Puget Sound Basin are either depressed ( 80 percent) or critical (20 percent). The pink and chum salmon appear to be reasonably healthy, with 53 to 66 percent of the stocks characterized as healthy, respectively (fig 4). For the chinook and coho salmon and steelhead trout, between 32 and 46 percent of the stocks are healthy and between 21 and 36 percent of the stocks are depressed. Those species with critical stocks include sockeye (20 percent), chinook (18 percent), pink (14 percent), and steelhead trout ( 3 percent). The status of many of the stocks is unknown, particularly for steelhead trout, because of limited population data.

Although many stocks of salmon and anadromous trout are critical or depressed, none have been federally listed as endangered at this time.

Within a specific river drainage, the status of the salmon and trout stocks is variable (table 2). For example, in many of the drainage basins within the Puget Sound Basin, one stock of salmon or trout may be healthy, while the remaining stocks are depressed. It is difficult to identify specific causes or factors for the variability in stock health within drainage basins, but it is most likely due to variations in habitat conditions, migration patterns of specific species of salmon and trout, river flow characteristics, seasonal anthropogenic factors, and variations in fishing pressure.

In addition to population declines, the average size and age of returning salmon has diminished during this century (Fraidenburg and Lincoln, 1985; Gall, 1991; Beatty, 1992). Chum and chinook along the Pacific Coast are now about one-half of their size in about 1920. The average size of coho has declined by about 3 pounds, or more than 25 percent in the past 40 years (Washington State Department of Fisheries, 1992). Possible contributing factors are changes in natural habitat that slow growth rates of salmon, effects of selective harvest, genetic changes resulting from interbreeding of wild and hatchery salmon (Reisenbichler and McIntyre, 1977), and an increase in the proportion of hatchery fish relative to wild fish.

Hatchery fish have played a significant role in salmon and steelhead population dynamics within the Puget Sound Basin. Between 1981 and 1994, over 1.5 billion fish were stocked in the streams and rivers of the Puget Sound Basin by the Washington State Department of Fish and Wildlife (Washington Department of Fish and Wildlife, 1996). The number and species of fish stocked has varied, based on drainage basin (fig. 5). Since 1981, more than 60 percent of all hatchery salmon and steelhead have been stocked in three main drainage basins: rivers and streams draining into Hood Canal (35 percent), smaller streams and rivers draining directly into Puget Sound (17 percent), and Nooksack River and its tributaries (10 percent). The composition of stocked salmon and steelhead has been dominated by fall chinook ( 39 percent), chum (34 percent), and coho ( 21 percent). Hatchery fish often mature earlier than wild fish and can therefore breed smaller and younger (Nicholson and others, 1986). Interbreeding between wild and hatchery fish results in smaller progeny (Fraidenburg and Lincoln, 1985; Beatty, 1992). A dramatic increase in the number of smaller hatchery salmon could decrease the average size and age of the entire salmon population.

Treaty Indian tribes in western Washington have also stocked hatchery fish within the streams and rivers of the Puget Sound Basin. Since 1976, the tribes in northwestern Washington have released more than 700 million salmon and steelhead throughout northwestern Washington (Northwest Indian Fisheries Commission, 1996). In 1995, tribal salmon and steelhead releases within the Puget 


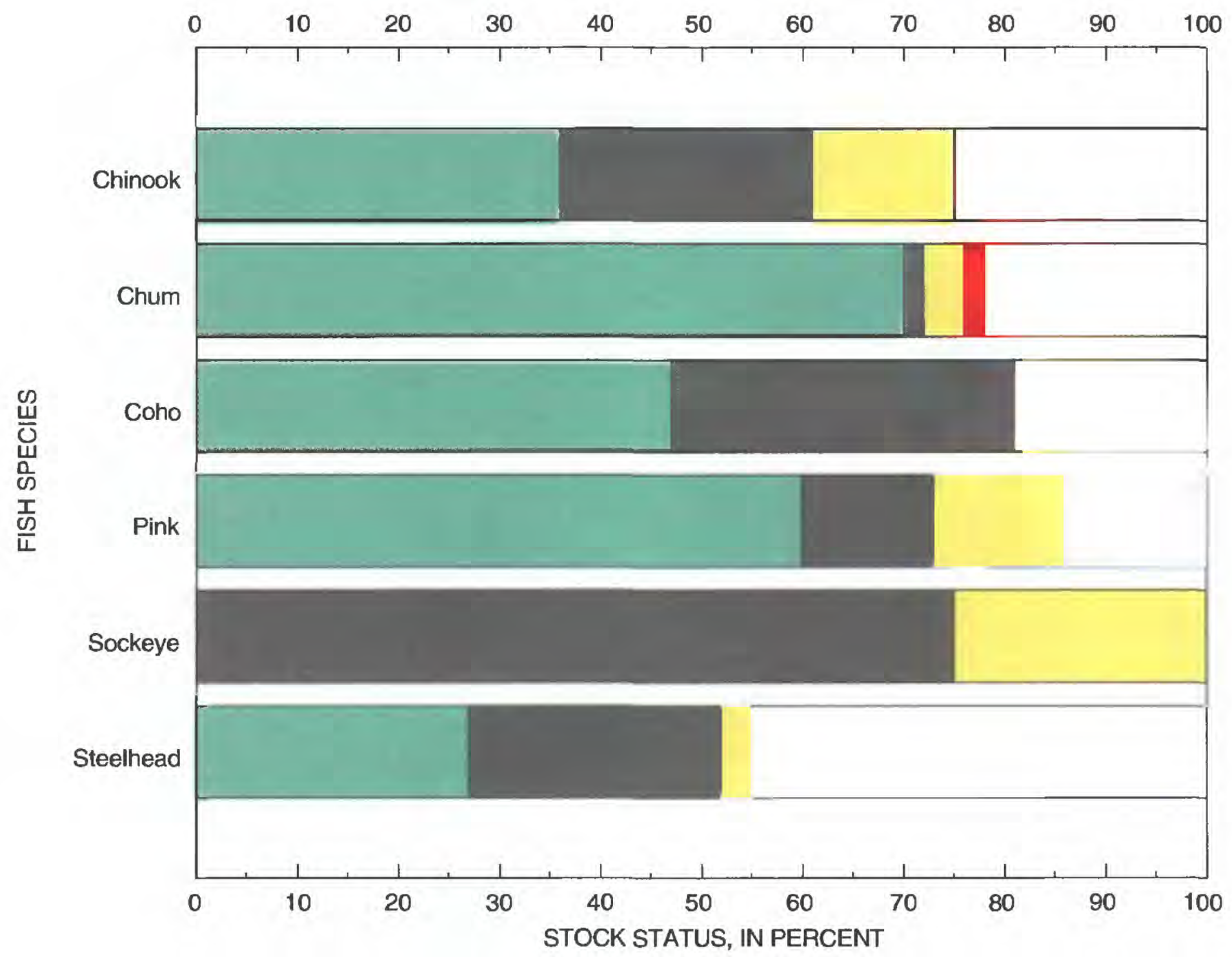

\section{EXPLANATION}

$\begin{array}{lll}\text { Healthy } & \square \text { Critical } \\ \text { Depressed } & \text { Extinct } \\ & \square \text { Unknown }\end{array}$

Figure 4. Salmon and steelhead stock status in the Puget Sound Basin. (Washington State Department of Fish and Wildlife and Western Washington Treaty Indian Tribes, 1994). 


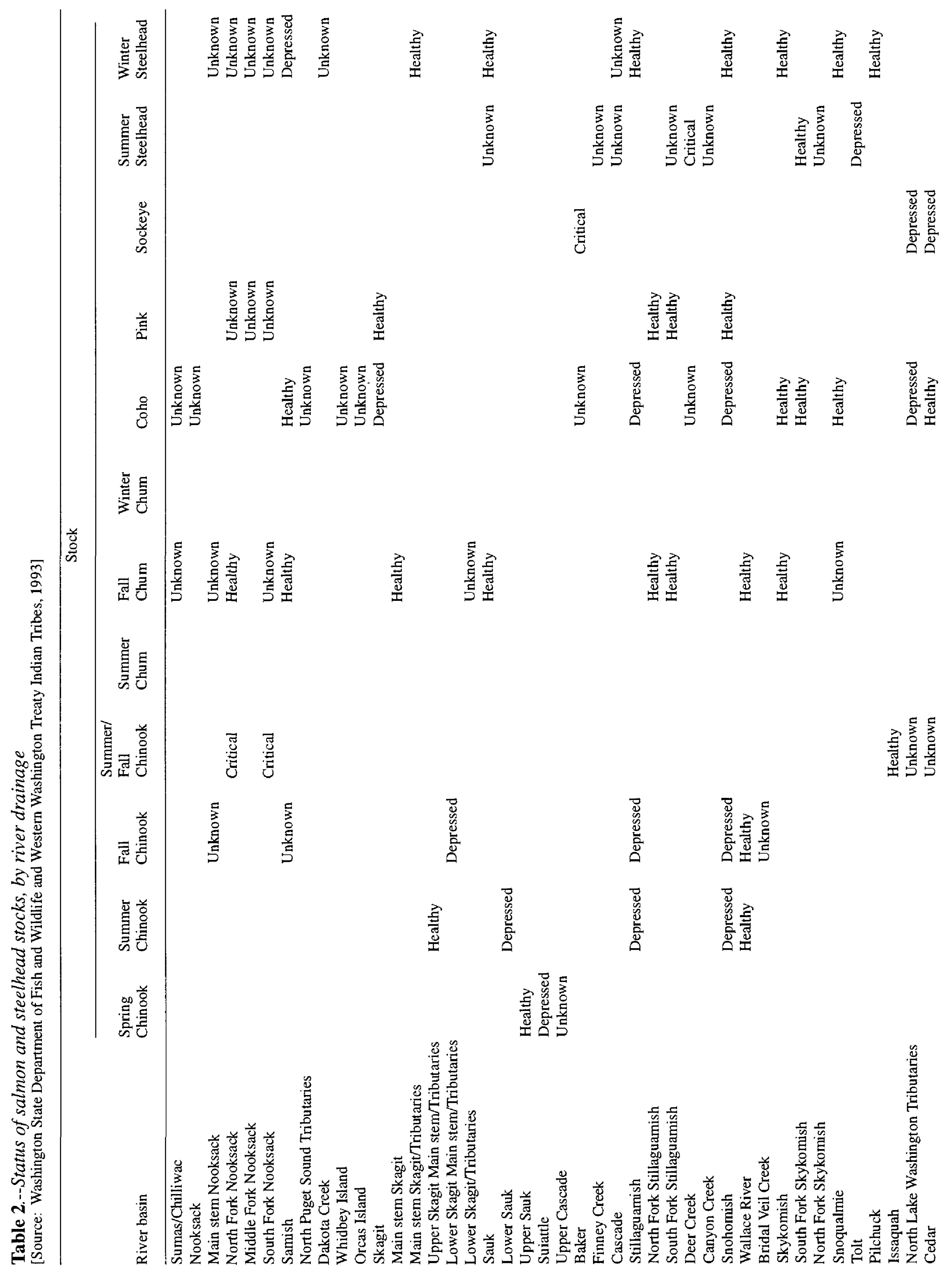




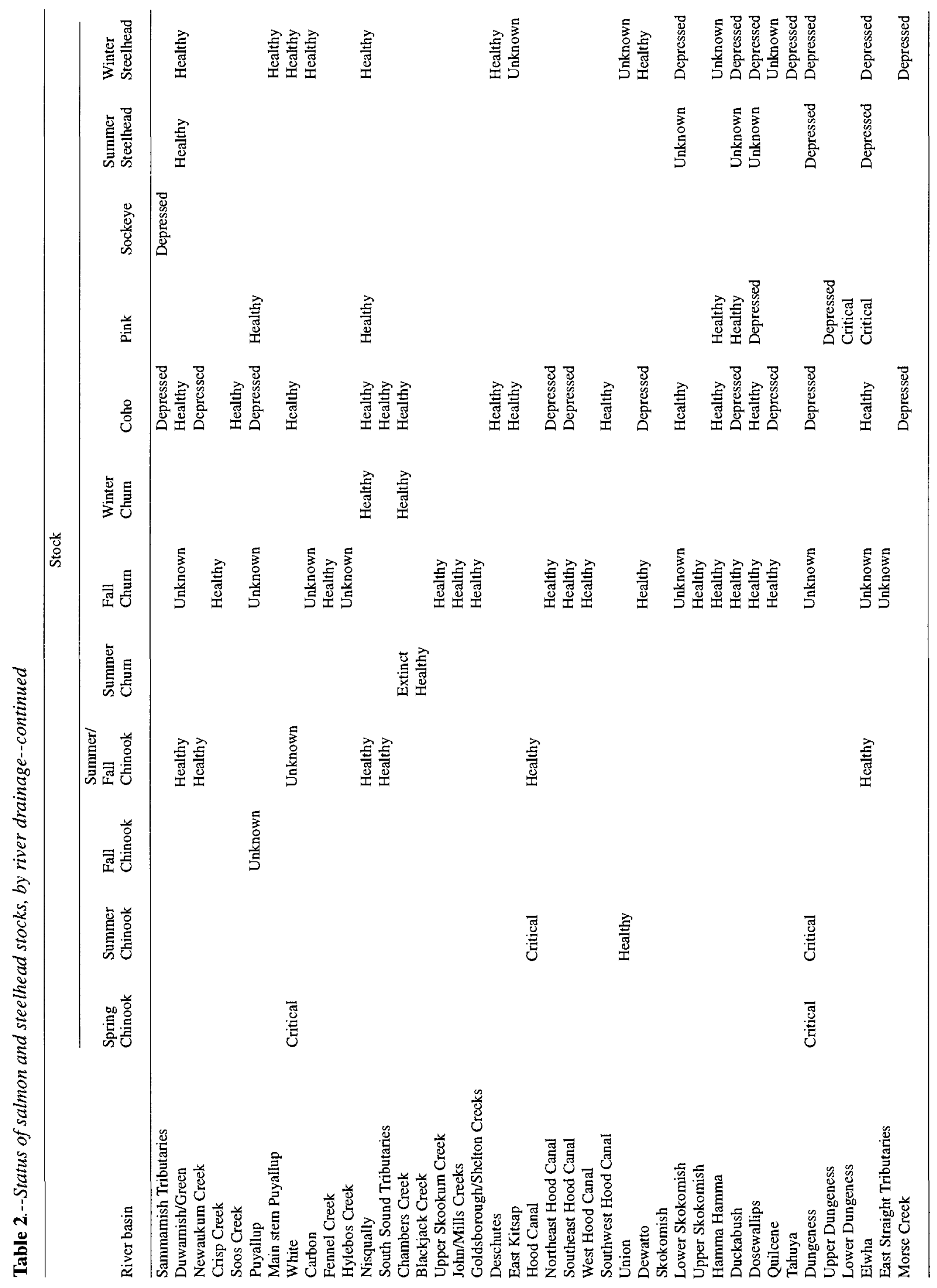




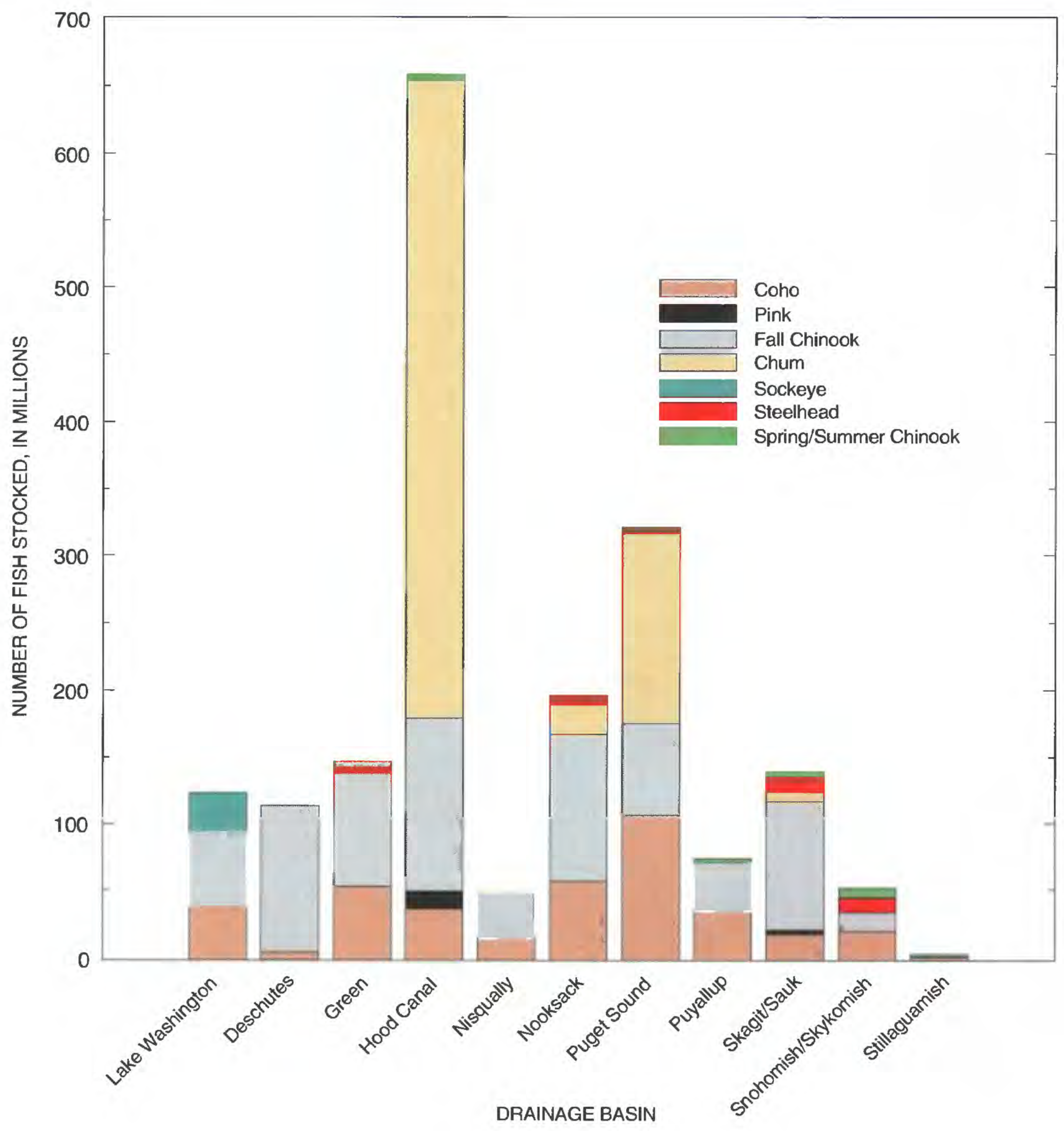

Figure 5. Salmon and steelhead stocked in Puget Sound Basin drainages by species, 1981-94. Stocking data is for Washington State Department of Fish and Wildlife hatcheries only. (Washington Department of Fish and Wildlife, 1996) 
Sound Basin equalled more than 45 million fish. The releases were composed of chum (38 percent), coho (32 percent), chinook ( 29 percent) and steelhead ( 1 percent).

The role that Puget Sound salmon play in the survival of the Pacific salmon may be significant, given the dwindling stocks of salmon throughout the western United States. Historically, Pacific salmon and anadromous trout were found throughout the region and State of Washington (fig. 6). While the status of some salmon (pink, chum) is relatively healthy within the Puget Sound Basin, the trend throughout the west is less encouraging. Salmon habitat within the western United States once equalled 2 to 68 million acres, depending on the species. Current available salmon habitat has declined anywhere from 6 percent to 59 percent from historical levels; much of the remaining habitat is suboptimal (The Wilderness Society, 1993). The loss of suitable habitat and other anthropogenic factors described above has resulted in a 39 percent to 57 percent reduction in wild chinook and coho production in the western United States (Bledsoe and others, 1989).

Changes in water quality may have contributed to the decline of salmon in Puget Sound Basin streams. However, this is just one of many factors, such as in-stream habitat and blockage of fish passage, that influence salmon populations. Salmon also spend a large portion of their life at sea and are affected by conditions in the ocean and by harvesting practices.

\section{Aquatic Benthic Macroinvertebrates}

Macroinvertebrates in this report refer to those organisms that spend some portion of their life cycle in streams or rivers on or within bottom sediments, debris, logs, macrophytes, or living or dead plant material. They are typically visible to the naked eye and generally larger than $0.6 \mathrm{~mm}$ (Rosenberg and Resh, 1993). Macroinvertebrate communities can have a dramatic effect on the water chemistry and biological integrity of a stream due to their role in organic matter processing and nutrient cycling. In addition, they are a critical component in the diets of many species of fish. A typical macroinvertebrate community includes insects, crustaceans, mollusks, annelids, flatworms, tubellarians and, occasionally bryozoans (Thorp and Covich, 1991).

The examination of macroinvertebrate communities can be an extremely valuable method for the assessment of water quality or biological integrity of a stream. First, macroinvertebrates inhabit most types of streams found throughout the world and are, therefore, exposed to numerous natural and anthropogenic disturbances. Second, there are numerous species of macroinvertebrates, each with their own unique environmental requirements and tolerances. Third, most macroinvertebrates are fairly sedentary, which allows one to evaluate disturbances spatially. Finally, macroinvertebrates have a fairly long life cycle within a particular location, which allows evaluation of temporal trends in disturbance (Rosenberg and Resh, 1993). It is the combination of these factors that makes macroinvertebrates ideal integrators of natural and anthropogenic disturbances over multiple temporal and spatial scales.

Aquatic macroinvertebrates have been examined by various studies throughout the Puget Sound Basin. However, only a limited number of studies have examined macroinvertebrate communities across a broad spatial scale to assess water quality within the Puget Sound Basin (Municipality of Metropolitan Seattle, 1977; Brenner and Morrice, 1978; Plotnikoff, 1992; and Kleindl, 1995).

Macroinvertebrates were collected for these studies from more than 130 unique sampling locations in over 80 streams and rivers within the Puget Sound Basin. These sampling sites were distributed across all of the ecoregions found in the basin in the following percentages: Puget Sound Lowland (79 percent), Coastal (15 percent), North Cascades ( 5 percent), and Cascades ( 1 percent). On the basis of available data, the following invertebrate taxa was identified: 7 phyla, 8 classes, more than 15 orders, more than 55 families, and more than 165 genera and species (table 3). One species of stonefly, Fender's soliperlan stonefly (Soliperla fenderi), is a Washington State species of special concern and a federal candidate for listing under the Endangered Species Act.

Although there are a number of advantages of using aquatic macroinvertebrates to evaluate changes in water quality, little macroinvertebrate monitoring has been done in the Puget Sound Basin. Recently, the Washington State Department of Ecology initiated a program that uses macroinvertebrates in a biomonitoring program (Plotnikoff, 1994). A pilot study was conducted in the early 90 's (Plotnikoff, 1992) to evaluate the sampling and analytical protocols for this program.

One of the most recent and comprehensive macroinvertebrate biomonitoring studies in the Puget Sound Basin was conducted in 19 low-order Puget Sound Lowland streams (Kleindl, 1995), which was designed to assess the impact of urbanization on biological integrity. Thirtyeight biological attributes (metrics) of macroinvertebrate assemblages were evaluated for responses to urbanization; nine of these metrics were found to be good indicators of 


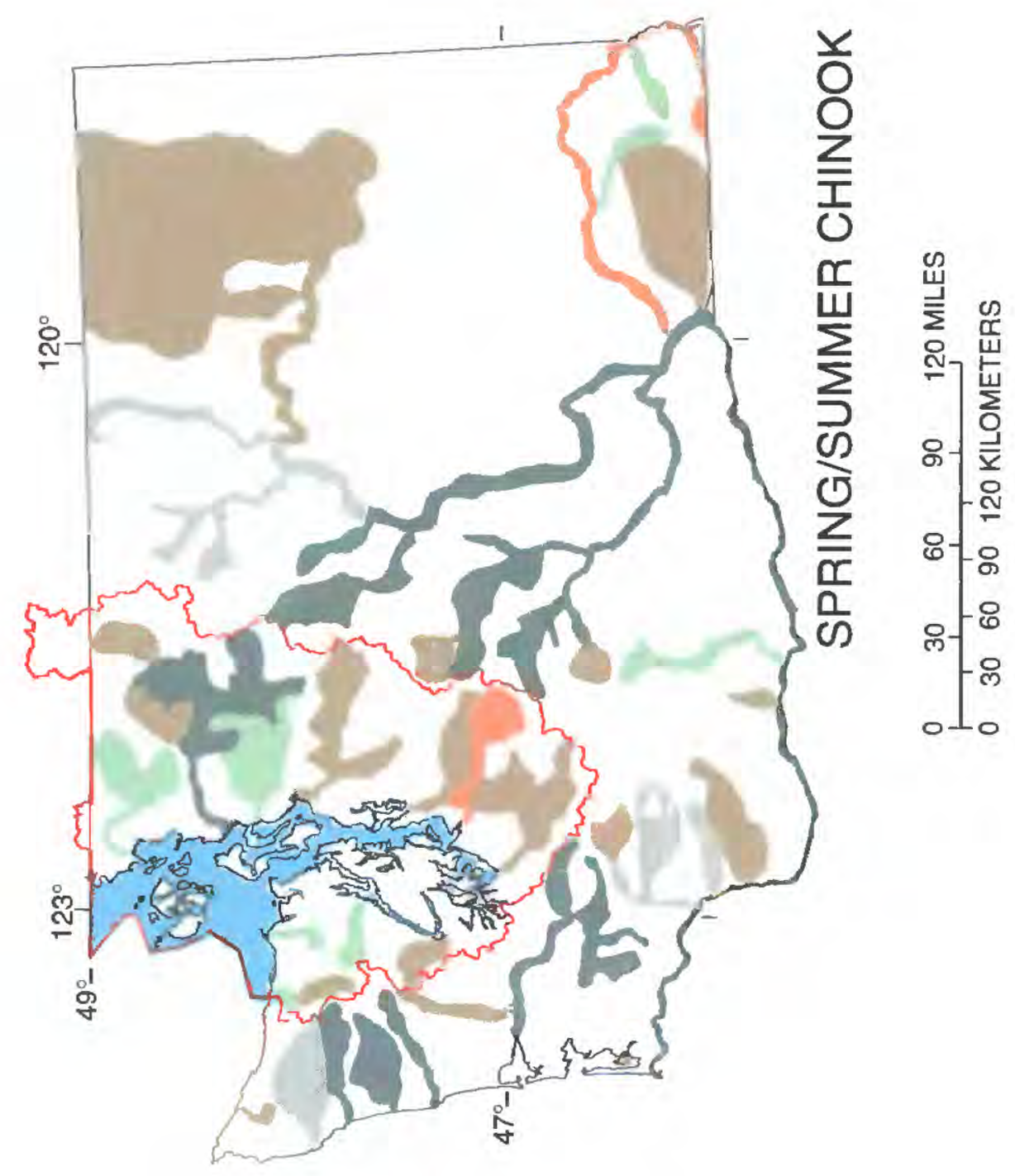

\%

幽 官

ㅎํㄴ

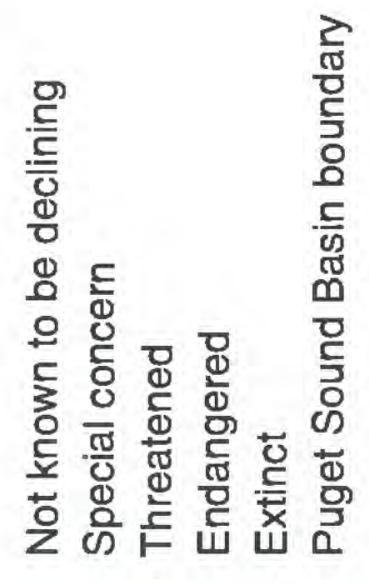

동

号

2

논 몬

3

옴

등 원

응

ฮั

w

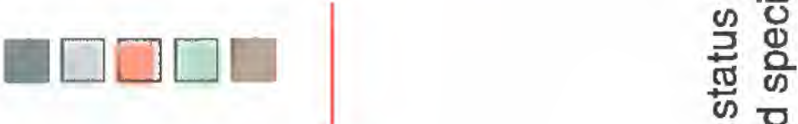

क) 응

站

돈 인

흐

क் 응

잉

잉
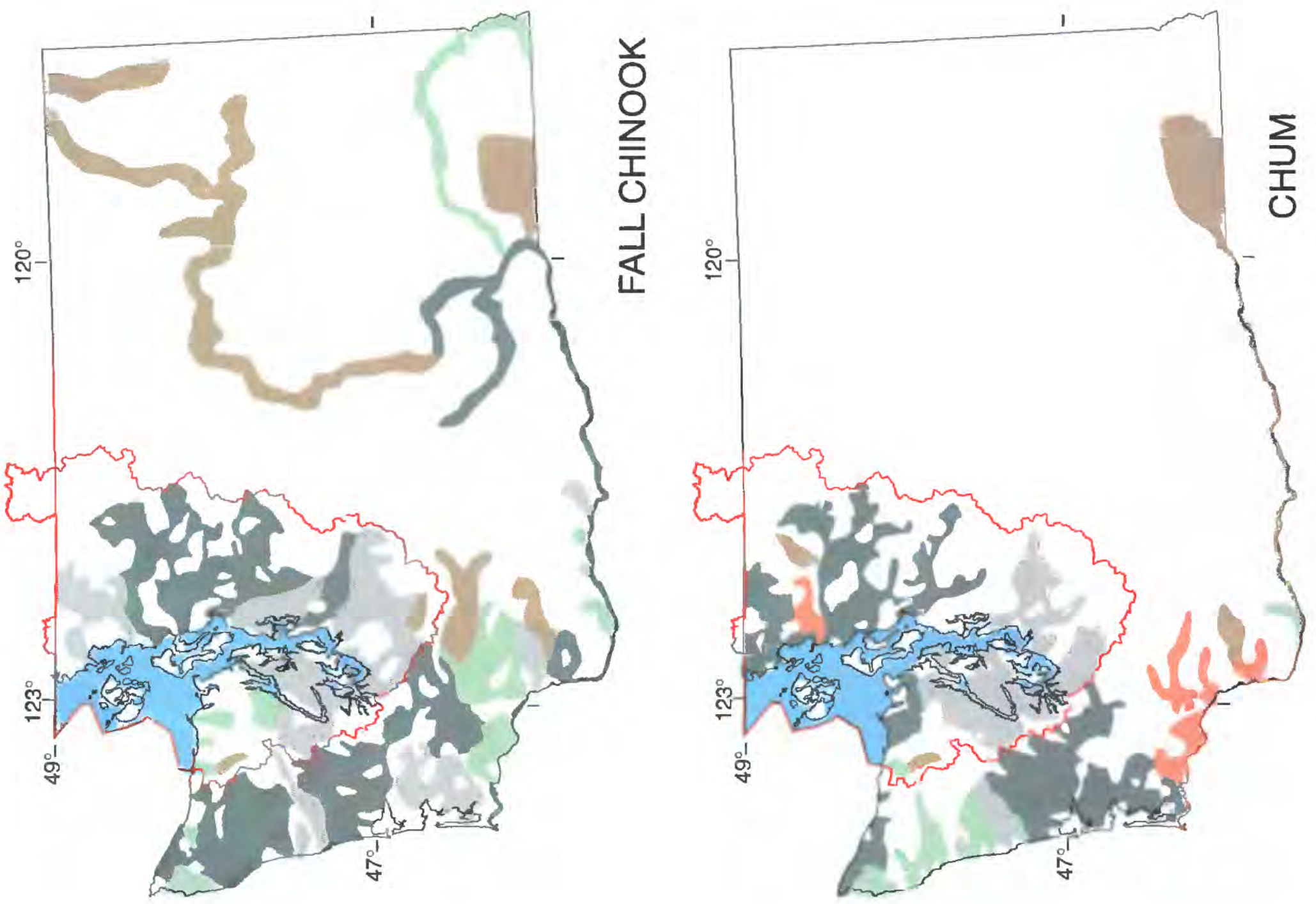

文需

동

훙

듣

$\sum_{0} \quad$ 蛋

든

은

需

है

은 딴

롱ㅎㅁ

믕

ᄃㄴㅇㅇ

हᄐ

忍

ㄷㅇㅇ

壳

อ

8ี

인 웅

믄 은 


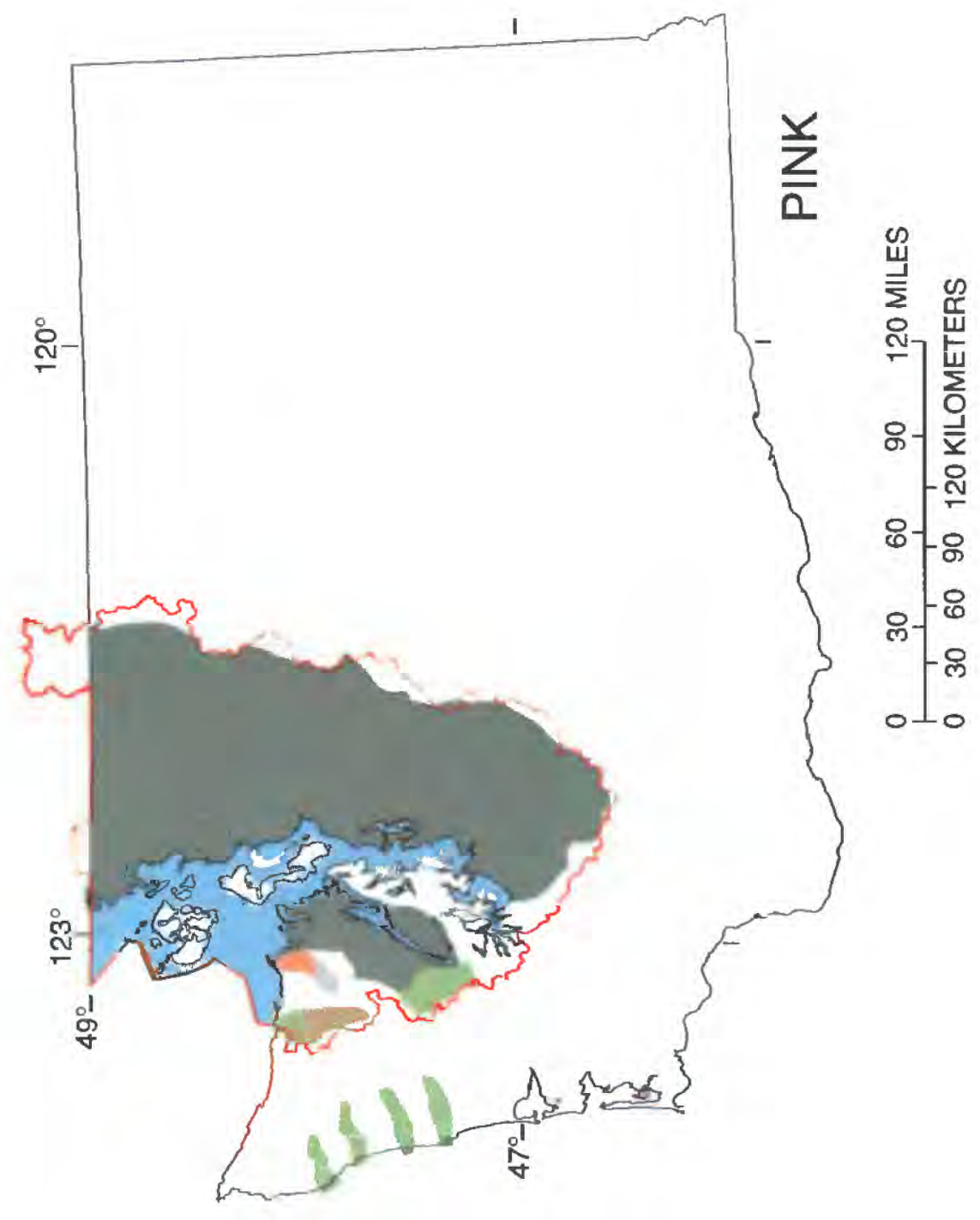

ริ

के

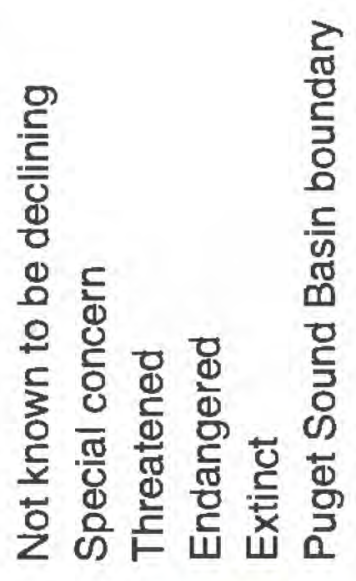

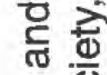

ธ్

돈

흥

은 은

은

동 일

옹

$\square \square \square \square \square$
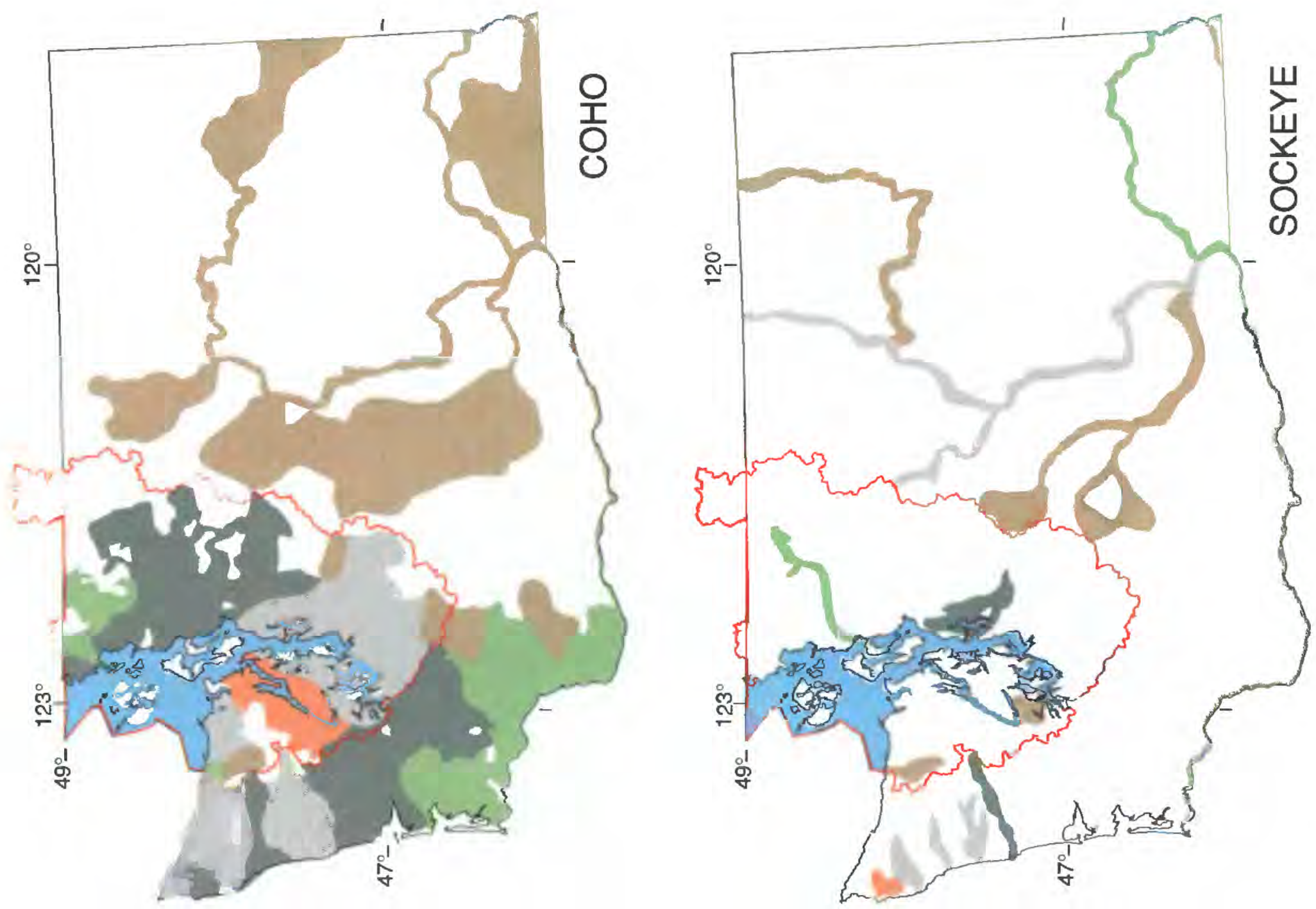

ลे

ш 등

山

돈

드

홍

要

हั ธे

흠 준

苋 प⿺辶寸

돈

등

है

芯豆

焉要

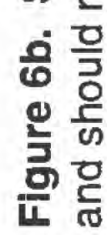




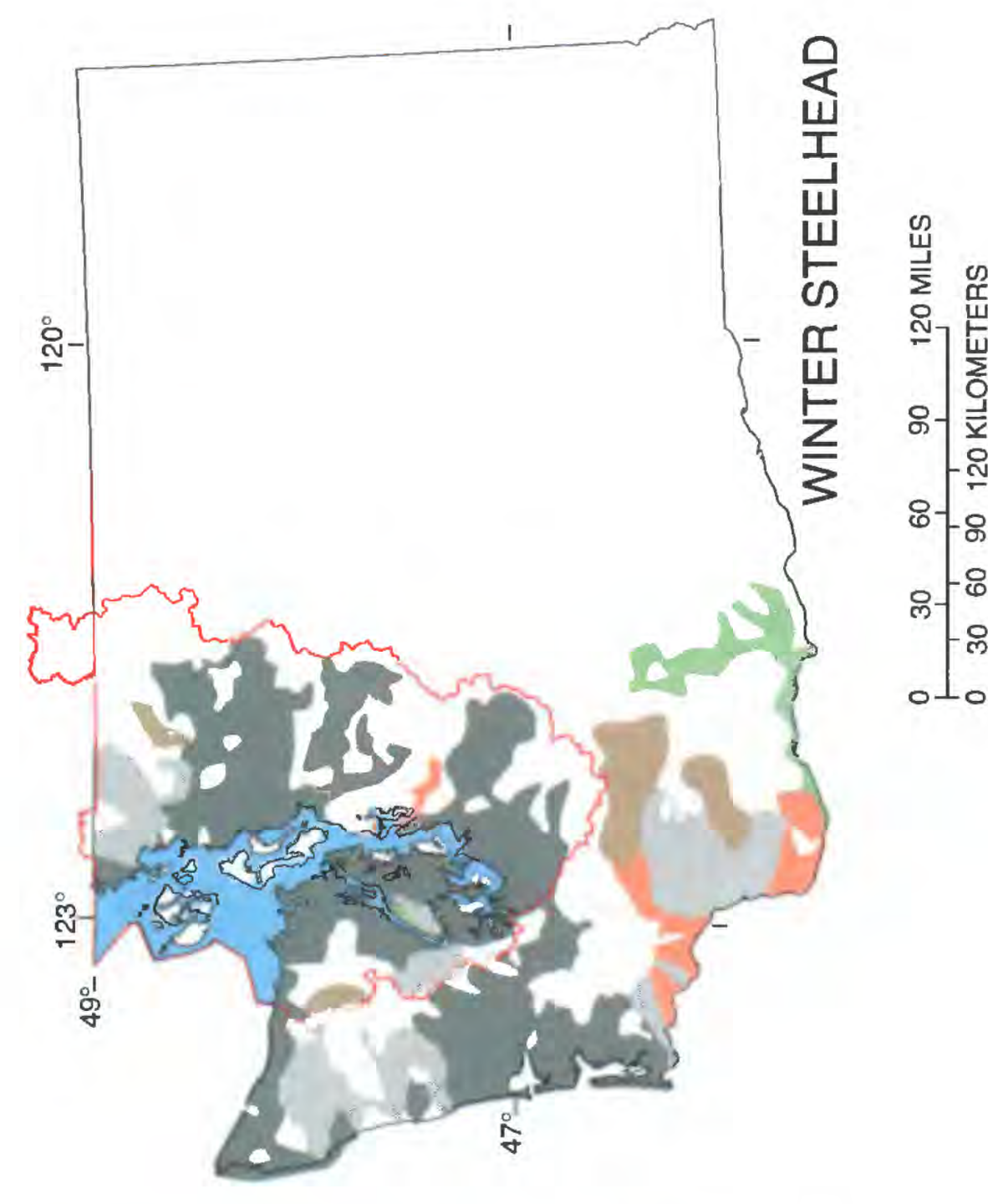

Б

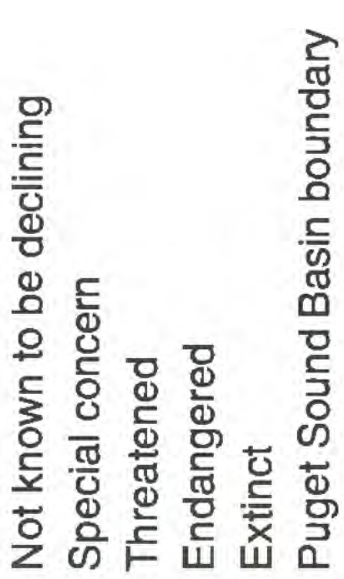

은

둥

등

당

응

홍

은

ᄃ

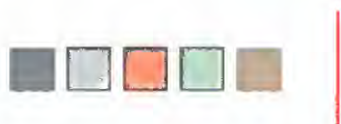

D

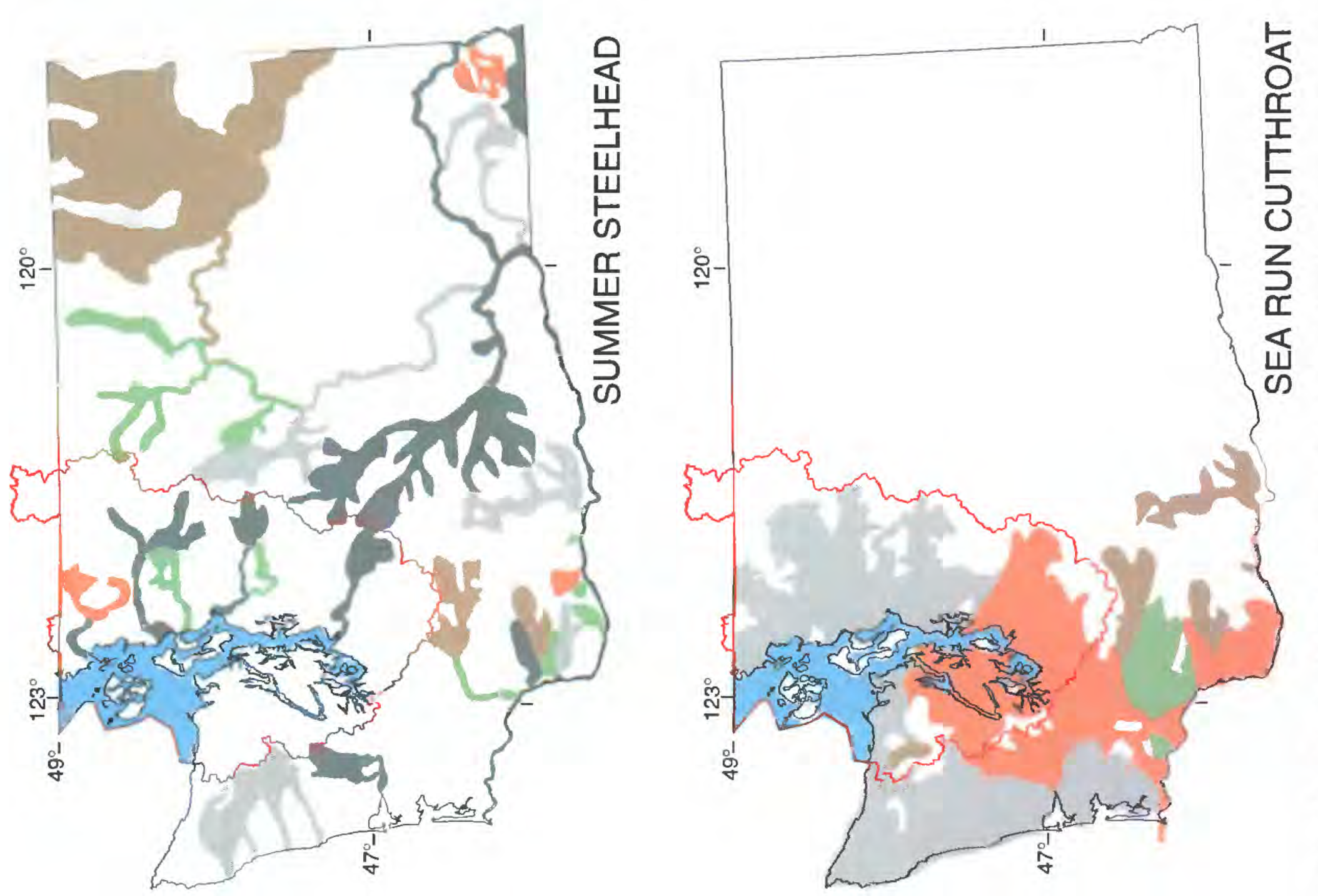

응 뭉

능

क

음

등

훙ㅁㅇ

के

需

등

항

웜

음

흔 흥

웜



宑

등

䟢

흥

공

का

흠

온 홍

혼듬 
Table 3.--Macroinvertebrates collected from Puget Sound Basin streams, 1977-1994

[Source of information: 1, Plotnikoff, 1992; 2, Kleindl, 1995; 3, Municipality of Metropolitan Seattle, 1977, and Brenner and Morrice, 1978; 4, G. Kraft, Western Washington University, written commun., Jan. 1995; 5, G. Kraft, Western Washington University, written commun., June 1995; 6, Matthews and others, 1991]

\begin{tabular}{|c|c|c|}
\hline Taxon (source) & Taxon (source) & Taxon (source) \\
\hline Annelida & Elmidae (continued) & Ptychopteridae (continued) \\
\hline Hirudinea $(2,3)$ - & Lara sp. $(1,2,3)$ & Ptychoptera sp. (1) \\
\hline Oligochaeta $(1,2,3)$ & Narpus sp. (3) & Simuliidae $(1,2,3,5,6)$ \\
\hline Enchytracidae (6) & Optioservus sp. $(1,2,3)$ & Simulium sp. $(1,2,3,5)$ \\
\hline Lumbriculidae $(1,6)$ & Promoresiasp. (2) & S. ectemnia (2) \\
\hline Rhynchelmis glandula (1) & Zaitzevia sp. $(1,2)$ & Tabanidae (5) \\
\hline Lumbriculidae sp.(1) & Haliplidae (5) & Tipulidae $(1,2,3,5)$ \\
\hline Naididae (2) & Hyrophilidae (5) & Antocha sp. $(1,2,3)$ \\
\hline Tubificidae (2) & Cymbiodyta sp. (5) & Dicronota sp. $(1,2,3,5)$ \\
\hline Arthropoda & Diptera (True flies) & Hexatoma sp. $(1,2)$ \\
\hline Arachnoidea & Blepharoceridae (3) & Limnophila sp. $(1,2)$ \\
\hline Acarina (3) & Ceratopogonidae (3) & Pedicia sp. (2) \\
\hline Hydracarina (water mites) (3) & Bezzia sp. (2) & Pilaria sp. (5) \\
\hline Crustacea & Chironimidae $(1,2,3,6)$ & Prionpcera sp. (2) \\
\hline Amphipoda (Scuds) $(1,3,6)$ & Chironomus sp. $(1,2,3)$ & Tipula sp. $(1,2)$ \\
\hline Talitridae (1) & Clinotanypus sp. (3) & Ephemeroptera (Mayflies) $(1,2,3)$ \\
\hline Hyalella azteca $(1)$ & Pentaneura sp. (3) & Baetidae $(1,2,3)$ \\
\hline Branchiopoda (3) & Tanytarsus sp. (3) & Baetis sp. $(1,2,3,5,6)$ \\
\hline Copepoda (3) & Dixidae & B. bicaudatus (3) \\
\hline Decapoda (Crayfish) & Dixasp. $(2,3,5)$ & B. tricaudatis (3) \\
\hline Astacide & Dixella sp. (2) & Ephemerellidae $(1,2,3,5)$ \\
\hline Pacifastacus sp.(1) & Empididae $(2,3)$ & Attenalla sp. (2) \\
\hline Isopoda (sow bugs) & Chelifera sp. (2) & Caudatella sp. $(2,5)$ \\
\hline Isopoda sp. $(1,2)$ & Muscidae (2) & Drunella sp. $(1,2.5)$ \\
\hline Insecta & Pelecorhynchidae $(1,2)$ & D. doddsi $(1,2)$ \\
\hline Coleoptera (Beetles) $(1,2,3,5)$ & Glutops sp. $(1,2)$ & D. coloradensis (1) \\
\hline Dytiscidae $(3,5)$ & Psychodidae $(1,2,3)$ & D. spinifera (1) \\
\hline Elmidae $(1,2,3)$ & Maruina sp. (I) & Ephemerella sp. (3) \\
\hline Ampumixis sp.(2) & Pericoma sp. $(1,2)$ & E. doddsi (3) \\
\hline Cleptelmis sp. $(1,2)$ & Psychoda sp. (2) & E. serratella (3) \\
\hline Heterlimnius sp. $(1,2,3)$ & Ptychopteridae & Serratella sp. $(1,5,6)$ \\
\hline
\end{tabular}


Table 3.--Macroinvertebrates collected from Puget Sound Basin streams, 1977-1994--continued

\begin{tabular}{|c|c|c|}
\hline Taxon (source) & Taxon (source) & Taxon (source) \\
\hline Ephemeridae (3) & Chloroperlidae (continued) & Nemouraidae (continued) \\
\hline Hexagenia sp. (3) & Haploplera sp. $(2,4)$ & Z. oregonensis (4) \\
\hline Heptageniidae $(1,2,3,5)$ & Kathroperla sp. (2) & Peltoperlidae \\
\hline Cinygmula sp. $(1,2,3,6)$ & $K$. perdita (4) & Sierraperla sp. (2) \\
\hline Epeorus sp. $(2,3,5,6)$ & Neaviperla forcipata (5) & Yoraperla brevis $(4,5)$ \\
\hline Ironodes sp. $(5,6)$ & Paraperla sp. $(2,5)$ & Y. mariana (5) \\
\hline Rhithrogena sp. $(1,2,3,5)$ & Plumiperla sp. $(2,5)$ & Perlidae $(1,2,3,4,5)$ \\
\hline Leptophlebiidae $(1,3,5)$ & Suwallia sp. $(2,4,6)$ & Attaneuria sp. (2) \\
\hline Leptophlebia sp. (5) & S. autumna (6) & Calineuria sp. $(1,2,3,5)$ \\
\hline Paraleptophlebia sp. $(1,3,6)$ & S. occidens (6) & C. californica (4) \\
\hline Paraleptaphelia bicor (3) & Sweltsa sp. $(1,2,4,5)$ & Doroneuria baumanni (5) \\
\hline Siphlonuridae & Triznaka sp. (2) & Hesperoperla sp. $(1,2)$ \\
\hline Ameletus sp. $(3,5)$ & Leuctridae $(2,3,4,5)$ & H. pacifica (4) \\
\hline Siphlonurus sp. (5) & Despaxia augusta $(4,5)$ & Perlesta sp. (2) \\
\hline Tricorythidae $(2,3)$ & Leucrinae sp. (3) & Perlodidae $(1,2,3,4,5)$ \\
\hline Hemiptera (True bugs) & Megaleuctra kincaidi (6) & Arcynopterx sp. (2) \\
\hline \multirow[t]{2}{*}{ Corixidae (3) } & Moselia sp. $(2,4,5)$ & Cascadoperla trictura (6) \\
\hline & M. infuscata (4) & Cultus sp. (1) \\
\hline Lepidoptera (Caterpillars) (2) & Paraleuctrasp. (4) & Diploperla sp. (2) \\
\hline Megaloptera & P. occidenta (4) & Isoperla sp. $(1,2,3,4,5)$ \\
\hline Sialidae $(2,5)$ & Nemouraidae $(1,2,3,4,5)$ & I. gravitans (6) \\
\hline Sialis sp. $(2,5)$ & Amphinemura sp. (2) & Kogotus $(4,5)$ \\
\hline Neuroptera (2) & Malenka sp. $(2,4,6)$ & Megarcys sp. $(4,5)$ \\
\hline Odonata (Dragonflies) & Nemoura sp. (1) & \\
\hline Gomphidae (1) & Ostrtocercasp. (4) & Perlinodes aura $(4,5)$ \\
\hline Gomphus (1) & O.foersteri (4) & Rickera sorpta (4) \\
\hline Plecoptera (Stoneflies) $(1,2,3,4,5)$ & Prostoia besametsa (6) & Setvena tibialis (4) \\
\hline Capniidae $(1,3,5)$ & Soyadenia sp. (4) & S. parallela (4) \\
\hline Capnia sp. $(1,4,5)$ & S. interrupta (6) & Skwala sp. $(2,5,6)$ \\
\hline C. excavata (4) & S. producta (4) & Pteronarcyidae $(1,2,4,5)$ \\
\hline C. melia (4) & Visoka cataractae (5) & Pteronarcella sp. $(1,2)$ \\
\hline Eucapnopsis sp. (4) & Zapada sp. $(1,2,3,4,5)$ & Pteronarcys princeps $(4,5)$ \\
\hline Mesocapnia oenone $(4,5)$ & Z. cinctipes (4) & Taeniopterygidae $(1,3,4)$ \\
\hline Utacapnia sp. (1) & Z. columbiana (4) & Doddsia sp. (1) \\
\hline Chloroperlidae $(1,2,3,4,5)$ & Z. frigida (4) & D. occidentalis (4) \\
\hline Allopera sp. (2) & Z. haysi (4) & Taenionema sp. $(1,4)$ \\
\hline
\end{tabular}


Table 3.--Macroinvertebrates collected from Puget Sound Basin streams, 1977-1994--continued

\begin{tabular}{|c|c|c|}
\hline Taxon (source) & Taxon (source) & Taxon (source) \\
\hline Trichoptera (Caddisflies) & Polycentropidae $(1,2,3)$ & \\
\hline Brachycentridae $(1,2,3)$ & Polycentropus sp. $(1,2)$ & \\
\hline Amiocentrus sp. (2) & P. Cymellus (2) & \\
\hline Brachycentrus sp. $(2,3)$ & P. Neureclipsis (2) & \\
\hline Lepidostoma sp. (2) & P. Nyctiophylax (2) & \\
\hline Micrasema sp. $(1,2)$ & Rhyacophilidae $(1,2,3)$ & \\
\hline Oligoplectrum sp. (2) & Rhyacophila sp. $(1,2,3,5,6)$ & \\
\hline Glossosomatidae $(2,3)$ & R. acropedes (3) & \\
\hline Agapetus sp. $(2,3)$ & Uenoidae (3) & \\
\hline Anagapetus sp. (2) & Mollusca & \\
\hline Glossosoma sp. $(2,3,6)$ & Bivalvia & \\
\hline Hydropsychidae $(1,2,3,5)$ & Sphaeriidae (3) & \\
\hline Arctopsyche sp. $(2,3,5)$ & Gastropoda (Snails) & \\
\hline Ceratopsyche sp. (1) & Ancylidae (3) & \\
\hline Hydropsyche sp. $(1,2,3,6)$ & Lymnaeidae (3) & \\
\hline Parapsyche sp. $(2,5,6)$ & Physidae (3) & \\
\hline Smicridea sp. (5) & Planorbidae $(1,3)$ & \\
\hline Hydroptilidae (2,3) & Gyraulus sp. $(1,6)$ & \\
\hline Hydroptila sp. $(2,3)$ & Pleuroceridae & \\
\hline Ochrotrichiasp. (2) & Juga sp. $(1,3)$ & \\
\hline Lepdostomatidae $(2,3,5)$ & Nematoda (3) & \\
\hline Lepidostoma sp. $(2,3,5)$ & Nematomorpha (3) & \\
\hline Limnephilidae $(1,2,3,5)$ & Platyhelminthes (3) & \\
\hline Apatania sp. (2) & Tubellaria (Flatworms) (3) & \\
\hline Clostoeca sp. (2) & Planariidae (2) & \\
\hline Cryptochia sp. (5) & Pelecypoda & \\
\hline Dicosmoecus sp. (3) & Sphaeriidae & \\
\hline Ecclisomyia sp. $(2,5)$ & Pisidium sp. (1) & \\
\hline \multicolumn{3}{|l|}{ Hydatophylax sp. (1) } \\
\hline \multicolumn{3}{|l|}{ Moselyana sp. (1) } \\
\hline \multicolumn{3}{|l|}{ Neophylax sp. (3) } \\
\hline \multicolumn{3}{|l|}{ Molannidae (2) } \\
\hline \multicolumn{3}{|l|}{ Molanna sp. (2) } \\
\hline \multicolumn{3}{|l|}{ Philopotamidae $(2,3,5)$} \\
\hline \multicolumn{3}{|l|}{ Dolophilodes sp. (5) } \\
\hline Wormaldia sp. $(2,5)$ & & \\
\hline
\end{tabular}


anthropogenic effects. The nine metrics were combined to form a multimetric benthic index of biotic integrity. It was determined that urbanization had a significantly greater impact on the composition of the macroinvertebrate communities of these streams than did the natural variability between streams. With increasing urbanization, the number of total taxa, the number of intolerant taxa (taxa intolerant to natural and anthropogenic disturbances), and the number of predator taxa all declined, while the percentage of intolerant taxa and the percent abundance of some intolerant taxa increased.

\section{STATUS AND TRENDS IN AQUATIC HABITAT}

Changes in aquatic habitat can directly influence aquatic communities. The evaluation of habitat conditions is necessary to assess biological integrity. In the early 1900 's, scientists recognized the role that stream and river habitats played in affecting fish and other aquatic biota (Steinmann, 1907; Shelford, 1911; Theinemann, 1912). The value of habitat in assessing stream quality was highlighted by the work of Fausch and others (1988). They examined approximately 100 mathematical models used to predict the abundance of fish from habitat conditions. The health of salmon in the Pacific Northwest has also been linked to habitat quality (Bisson and others, 1992). Habitat conditions can also affect water chemistry within a stream. Likens and others (1970) and Newbold and others (1981) found that nutrient concentrations were affected by habitat conditions. Within the Puget Sound Basin, aquatic habitats have been considerably altered by natural and human activities.

In the nineteenth century, the federal government claimed jurisdiction over water navigation and proceeded to straighten rivers and streams and clear them of large organic matter to allow steamboats, log rafts, barges and other vessels unimpeded passage. In addition, many nonnavigable streams were cleared and straightened to facilitate the transport of timber from the headwaters to the mills downstream. The clearing and straightening of streams was particularly common in the Pacific Northwest. By the early 1880 's, most timber within 2 miles of Puget Sound had been logged (Buchman, 1936). Loggers and engineers cleared streams to improve the movement of floated logs and enhance the effectiveness of splash dams used to create holding lakes to transport logs downstream (Sedell and Duval, 1985). Before a stream could be used to transport logs, it had to be improved (Brown, 1936). $\mathrm{Im}_{\mathrm{l}}$ rovements included blasting out or removing boulders, large rocks, leaning trees, sunken logs or obstructions of any kind. By the 1880 's, a portion of most streams within the Puget Sound Lowlands had been improved for log transport (Cox, 1974), and by 1900 there were more than 130 companies involved in river and stream improvement operations in Washington (Sedell and Duval, 1985). According to Sedell and Duval (1985), more than 150 log-transporting or splash dams were in western Washington. Splash dams had the potential to significantly alter the physical and biological condition of many streams by creating debris-laden floods that scoured out channels, thereby reducing habitat complexity (Harmon and others, 1986).

While habitat plays a critical role in the overall quality of aquatic systems within the Puget Sound Basin, to date only a limited number of reports have summarized existing habitat conditions and data (Ralph and others, 1991; Ralph and others, 1994), in spite of the abundance of habitat data collected by timber companies, federal agencies (U.S. Forest Service, U.S. Fish and Wildlife Service, National Park Service), state agencies, Indian tribes, county and municipal agencies, and universities. A number of efforts are underway to organize existing habitat data into watershed and regional scale summaries and evaluations (Schuett-Hames and others 1994; Salmon and Steelhead Habitat Inventory and Assessment Project, 1995).

Ralph and others $(1991,1994)$ provided one of the first quantitative summaries of in-stream habitat in forested lands of western Washington. Their in-stream habitat data set was composed of information collected from over 200 stream study sections sampled from 1989-91 using accepted sampling techniques (Hankin and Reeves, 1988; Ralph and others, 1991). Study sections were from $126 \mathrm{~m}$ (meters) to $39 \mathrm{~km}$ (kilometers) long. They found that the number of pieces of in-stream large woody debris (a piece of wood more than $10 \mathrm{~cm}$ (centimeters) in diameter and more than $2 \mathrm{~m}$ long) was not significantly different between harvested and unharvested watersheds, but in-stream wood was significantly smaller in streams that drained harvested watersheds. Timber harvest also resulted in more wood located on the margins of streams outside the low-flow wetted width of the channel. Although they did observe a general reduction in habitat complexity and an increase in riffle habitat in the streams that drain harvested watersheds, the trends were variable and often related to specific channel and valley geomorphology, in addition to harvesting.

Habitat information for those streams located in the Puget Sound Basin found in the data set of Ralph and others (1991) was extracted by the authors of this report 
and combined with two data sets from the U.S. Forest Service. The U.S. Forest Service data sets included instream habitat data for streams located in the Green River watershed and the Hood Canal area. The data were collected from 1991 to 1994, utilizing techniques similar to those used by Ralph and others (1991). The combined data set was used to examine some in-stream habitat conditions for streams within the Puget Sound Basin and are presented in figure 7 .

The abundance of large woody debris plays an important role in the structure and function of streams and rivers in the Puget Sound Basin. Bilby and Ward (1989) found that the woody debris in undisturbed old-growth forests in western Washington declined as stream width increased. The streams sampled by the U.S. Forest
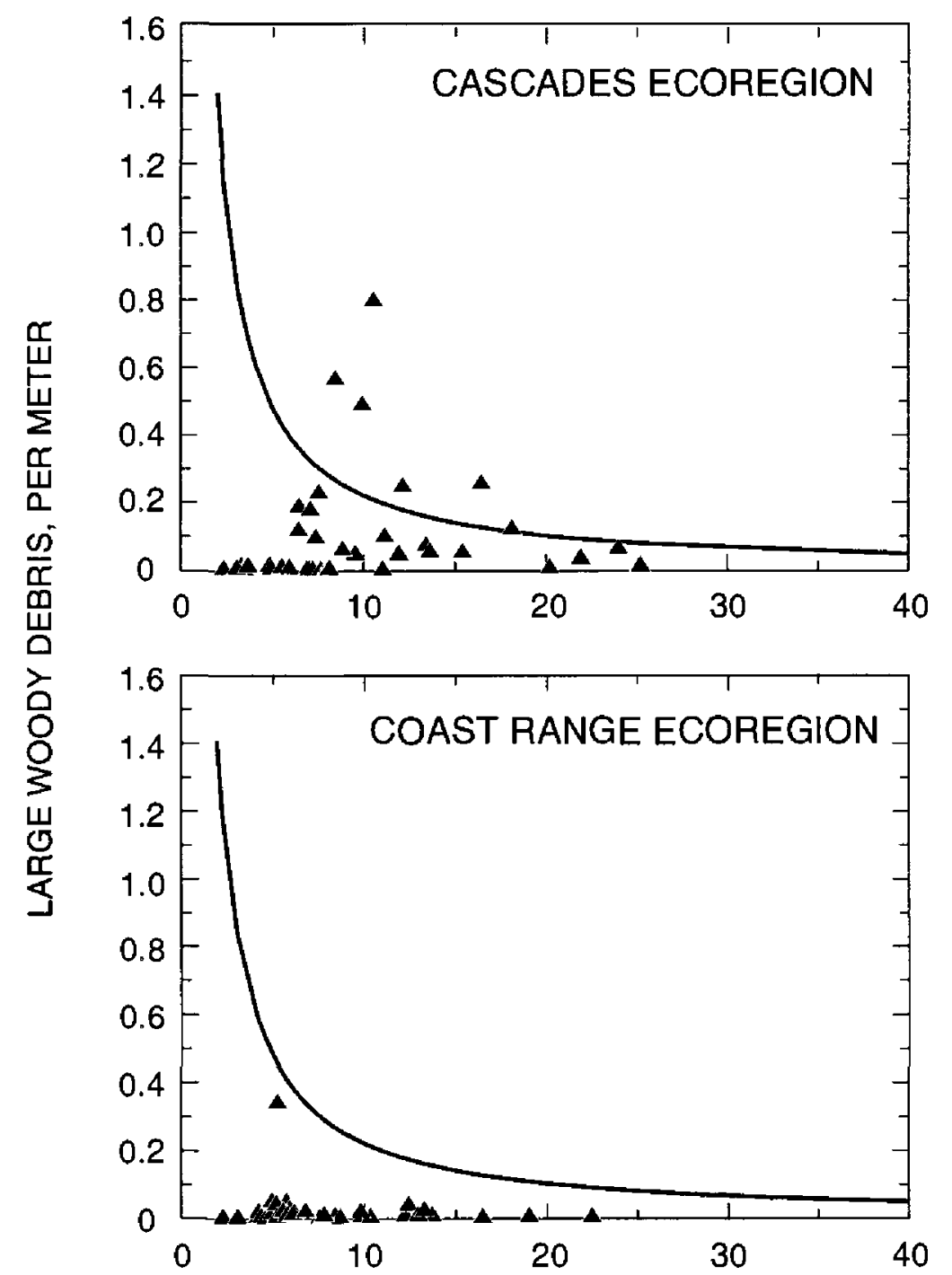

Service and Ralph and others (1991) did not follow the pattern observed by Bilby and Ward (1989) (fig. 7). Most of the Puget Sound Basin streams in the data sets of Ralph and others (1991) and U.S. Forest Service were located in harvested watersheds. For many of the small streams found in all four of the Puget Sound Basin ecoregions, the abundance of in-stream woody debris was well below that found in streams draining old-growth forests examined by Bilby and Ward (1989). In-stream woody debris was particularly low in the Coast Range and Cascades ecoregion streams (fig. 7). It is important to note that Bilby and Ward (1989) did not evaluate instream woody debris based on ecoregions. The relationship between stream width and large woody debris for old growth conditions presented in figure 7 should be viewed as a general relationship for northwestern old growth forests.
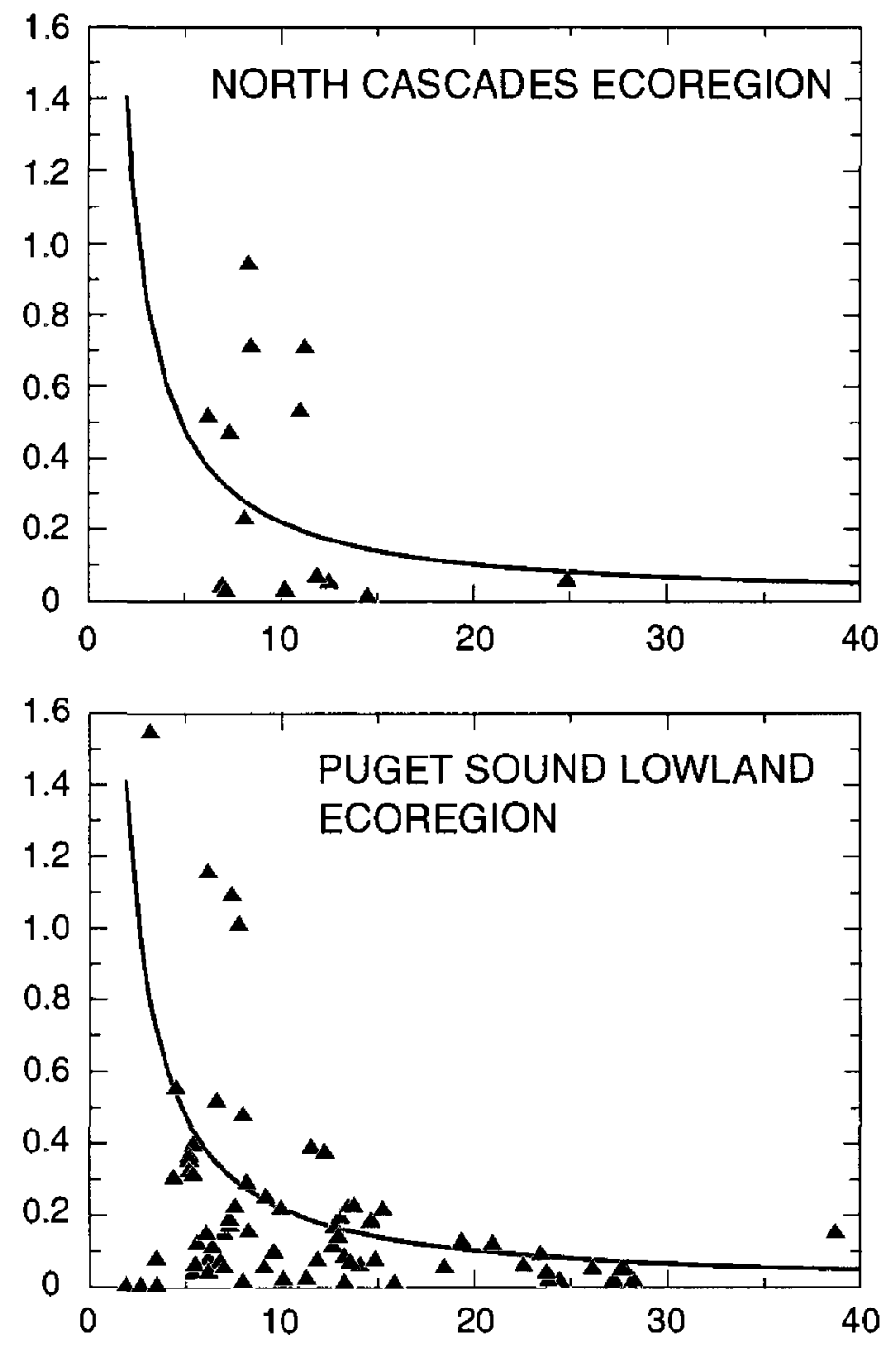

\section{EXPLANATION}

\section{- Old Growth Conditions (Bilby and Ward, 1989) \\ - Current Conditions (Ralph and others, 1991)}

Figure 7. The relationship between pieces of large woody debris and stream width, by Puget Sound Basin ecoregion. 
The abundance of pools is another measure of a stream's ability to support fish and other aquatic organisms. For many species of fish, pools provide both a safe and energetically favorable habitat (Fausch, 1984; Wilzbach, 1985). The removal of wood from streams, changes in discharge, sedimentation, channelization and other anthropogenic factors can reduce the number of pools within a stream. The U.S. Forest Service (1993) found that the number of pools in many of the streams in forested areas of the Puget Sound Basin were well below historic levels (fig. 8). In some of the stream study reaches examined in the Hood Canal drainage, pools were entirely absent (U.S. Forest Service, 1993).
In 1994, the Washington State Department of Fish and Wildlife and the Western Washington Treaty Indian Tribes prepared the Salmon and Steelhead Stock Inventory (SASSI) report. The inventory summarizes the status of salmon and anadromous trout stocks in the basins of western Washington (Washington Department of Fish and Wildlife and Western Washington Treaty Indian Tribes, 1993; 1994). As part of the stock assessment, a written description of the factors affecting production was provided for those drainages for which there was sufficient information. The types of disturbances affecting salmon production were identified. A summary of the natural and anthropogenic disturbances identified in the SASSI report

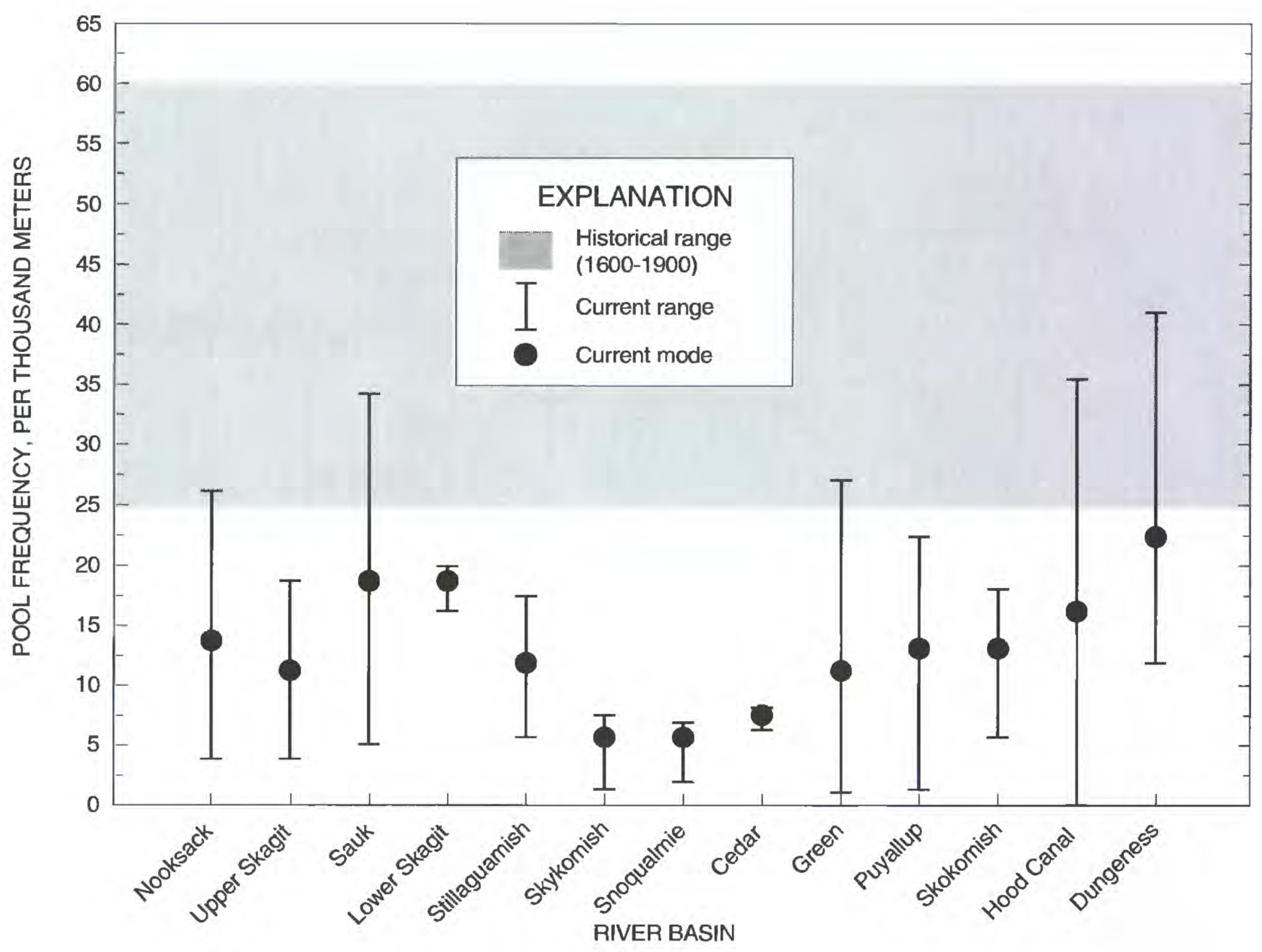

Figure 8. Pool frequency, by river basin. (Source: U.S. Forest Service, 1993) 
that are affecting salmon stocks in the Puget Sound Basin is presented in figure 9. Figure 9 shows the percentage of time that each disturbance type was identified as a factor affecting either depressed or critical salmon stocks. For depressed stocks of salmon, agricultural diking, logging sedimentation, and the lack of in-stream woody debris appeared to be the most significant factors affecting salmon production. For critical stocks, logging sedimentation was the most cited factor affecting salmon stocks. However, the abundance of dams and fish barriers, high erosion, high water temperatures, and the lack of in-stream woody debris, riparian vegetation, and pools all are equally identified as factors affecting salmon in the Puget Sound Basin (fig. 9).

Dams and fish barriers can have a substantial effect on both migratory and resident species of aquatic biota. Not only do dams and barriers prevent or limit migratory (anadromous) salmon from accessing critical habitat (Nehlsen and others, 1991), they can alter the water chemistry of streams by eliminating the decomposing carcasses of spawned-out salmon (Bilby and others, 1996). Within the Puget Sound Basin, the U.S. Army Corps of Engineers has identified over 260 dams, which are in their 1993-94 data base (U.S. Army Corps of Engineers, 1994) (fig. 10). Based on the Washington State Department of Fish and Wildlife's fish passage data base (1995), more than 60 of these dams are impassable to fish. Of over 500 stream basins examined by the Washington Department of Fish and Wildlife, over 800 fish passage barriers have been identified, with less than 10 percent of them dams. Water diversions, culverts, and natural barriers account for most of the remaining fish barriers. In the Nooksack Basin, approximately 90 fish barriers have been identified; 75 percent of these barriers are natural (Washington Department of Ecology, 1995).

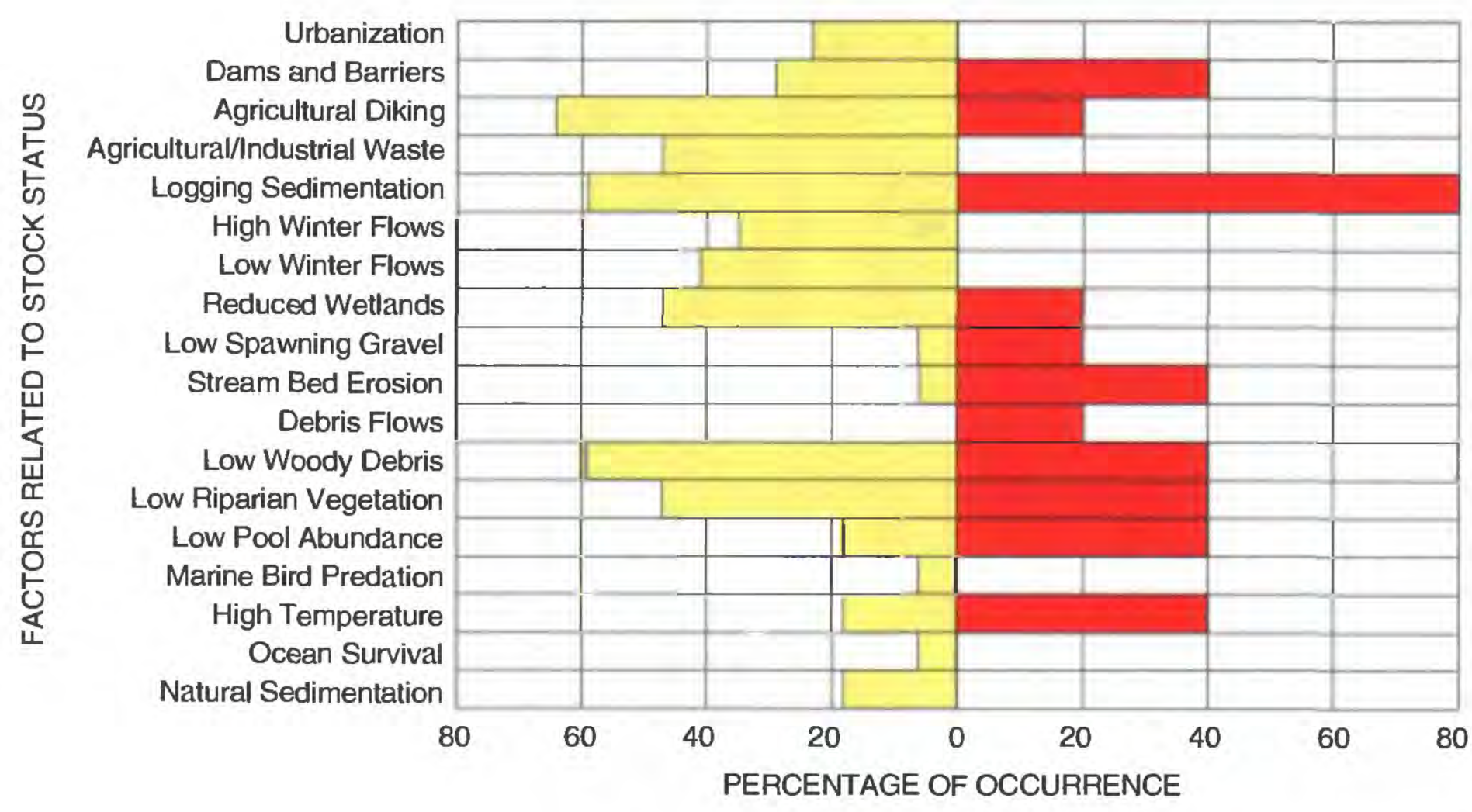

\section{EXPLANATION}

Depressed status salmon stocks $\square$ Critical status salmon stocks

Figure 9. Factors related to salmon stock status. (Data from Washington State Department of Fisheries, 1994) 


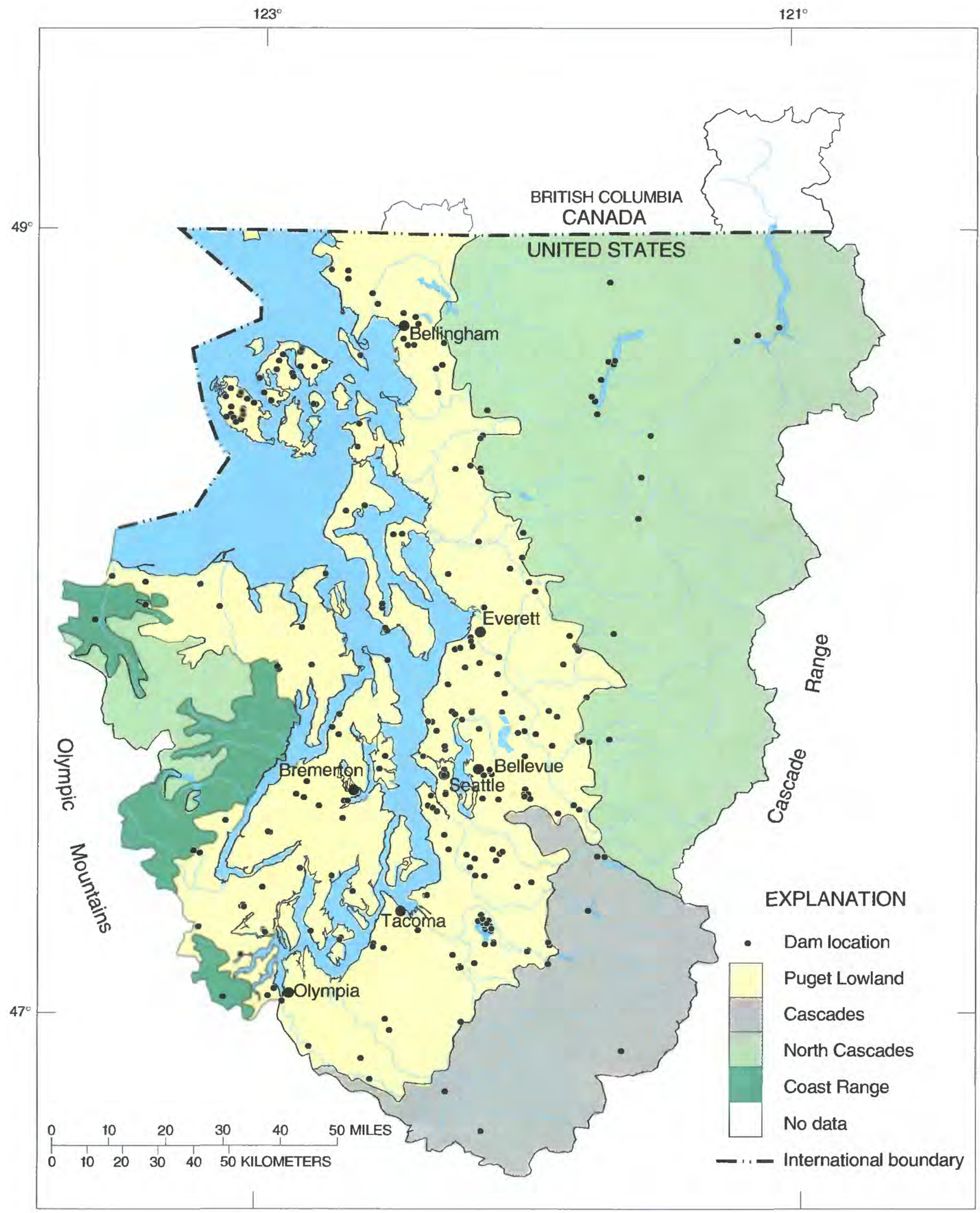

Figure 10. Location of dams and ecoregions in the Puget Sound Basin. Modified from Omernik and Gallant, 1986, and U.S. Army Corps of Engineers, 1994. 
The quality of stream and river habitat is critical to the reproduction and survival of aquatic organisms. In addition, the measurement of habitat variables can provide a current and temporal measure of water quality. However, without long-term habitat measures, it can often be difficult to interpret habitat in terms of historical conditions. As noted by Bisson and others (1992), long-term habitat monitoring has not taken place in most Pacific Northwest river systems. By the time many streams were surveyed, their habitats had already been altered by anthropogenic factors.

Habitat conditions can also affect the water temperature of a stream or river. The quantity and type of instream structure, as well as the abundance of topographic features and vegetation adjacent to a stream, can affect water temperature. Changes in temperature can affect aquatic organisms by altering metabolic rates and oxygen requirements, altering their sensitivity to toxic compounds and affecting their ability to avoid predators. All aquatic organisms have optimal temperature ranges for maintaining health. For example, the optimal temperature range for salmon migration is between $3.3^{\circ} \mathrm{C}$ and $20.0^{\circ} \mathrm{C}$. The optimal range for salmon and resident and anadromous trout spawning and incubation are $2.2^{\circ} \mathrm{C}$ to $20.0^{\circ} \mathrm{C}$ and $4.4^{\circ} \mathrm{C}$ to $14.4^{\circ} \mathrm{C}$, respectively (Reiser and Bjornn, 1979). Urbanization, logging and agricultural activities can all affect water temperature. However, the influence of natural environmental factors, such as ground-water inflow, can also affect stream temperatures.

Water temperatures are monitored throughout the state by local, state, tribal, and federal agencies. Many of these agencies prepare reports to summarize their findings. However, studies performed to evaluate stream water temperatures and their relationship to environmental factors throughout the Puget Sound Basin are limited (Collings, 1973; Sullivan and others, 1990).

One of the most recent and extensive studies in Washington was performed by Sullivan and others (1990). More than 90 temperature monitoring sites were evaluated throughout the state; 25 sites were located within the Puget Sound Basin. Each sampling site or thermal reach was at least 600 meters long. Temperature was measured at the downstream end of the thermal reach, and riparian vegetation and shading conditions were evaluated throughout the reach. Water temperature was measured hourly, primarily during the late spring throughout early fall of 1988, the warmest time of the year. Although many factors affect water temperature, Sullivan and others (1990) evaluated their data in terms of riparian shading. Figure 11 presents the average minimum, average mean, and average maximum temperatures from July 15 through August 15 for sites monitored in the Puget Sound Basin. This evaluation period was selected because it represents the statistically warmest 30-day period of the year.

Included in figure 11 are the percentages of riparian shading for each sampling location. Of the 25 sites examined, 15 sites exceeded the Washington State Department of Ecology's Class-AA (highest quality) instantaneous measure of $16^{\circ} \mathrm{C}$. Nine of the 15 streams also exceeded the states Class-A (high quality) instantaneous standard of $18^{\circ} \mathrm{C}$. Of the 15 streams exceeding the $16^{\circ} \mathrm{C}$ standard, 12 had less than 50 percent of the reach shaded by riparian vegetation.

Although Sullivan and others (1990) found a strong relationship between shading and water temperature, riparian vegetation and shading are not the only factors affecting stream water temperature. Numerous natural and anthropogenic variables such as geography, climate, stream channel characteristics, agriculture, forest practices, and urbanization can affect water temperature.

\section{STATUS AND TRENDS OF CONTAMINANTS IN FISH TISSUE}

The evaluation of trace elements and organic compounds in the tissues of fish and other aquatic organisms can indicate spatial and temporal trends in water quality. Evaluation of tissue contaminants can also help assess the health of individuals as well as the potential for contaminants to influence other organisms throughout the food web. Contaminants can also influence species richness as well as community composition. Consequently, analyzing for tissue contamination can help assess the biological integrity of a stream or river as well as trends in water chemistry.

As noted by Phillips (1980), tissue analyses have three distinct benefits in determining trends in water quality. First, bioaccumulation of contaminants in the tissues of aquatic organisms increases the likelihood of identifying the presence of trace amounts of these contaminants in the environment. Second, measurements of contaminants in the tissues of aquatic organisms provide a time-average assessment of contaminants. Third, concentrations of contaminants in the tissues of aquatic organisms provide a direct measurement of the bioavailability of contaminants. It is often difficult to determine the bioavailability of a contaminant based solely on the concentration of that contaminant in the water or sediment. Additional advantages of tissue analyses are that they provide a source of information in understanding the complexities of the fate, 


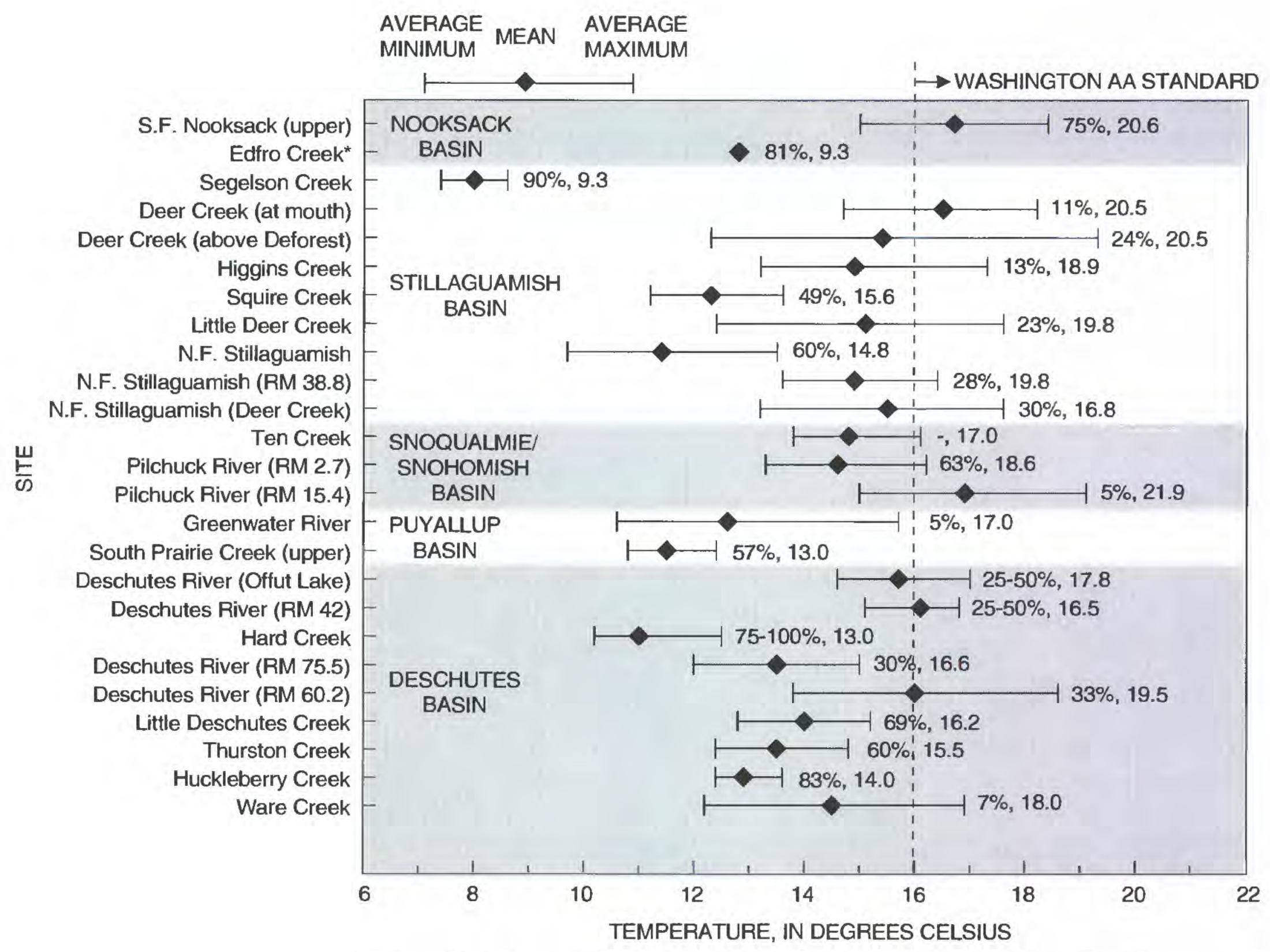

Figure 11. Average minimum, mean, and maximum stream temperature for July 15 to August 15, 1988, for selected sites within the Puget Sound Basin. The percentages represent the amount of stream shading followed by the maximum instantaneous temperature recorded. The vertical dashed line is the Washington AA standard to maintain trout and salmon (highest quality for human consumption and the maintenance of aquatic life) *missing minimum and maximum data. (Sullivan and others, 1990)

distribution and effects of various contaminants, and that tissue analyses can be used as indicators of potential risk to the health of humans and wildlife (Crawford and Luoma, 1993; Maret, 1995).

Most fish tissue data within the Puget Sound Basin are samples collected from the salt waters of Puget Sound. Since 1988, the Puget Sound Ambient Monitoring Program (PSAMP) has been coordinating a multiagency sampling program designed to assess the health of Puget Sound (Puget Sound Water Quality Authority, 1995). As part of this program, two agencies (Washington Department of Fish and Wildlife, and Washington Department of Health) have been collecting and analyzing tissue samples from marine fish and invertebrates within Puget Sound at 3 to 18 sites per year from 1989 to 1994 for fish tissue and
10 to 20 sites per year from 1990 to 1993 for shellfish tissue. Both fish and invertebrate tissues contained trace elements and synthetic organic compounds at many of the sites sampled, particularly near U.S. Environmental Protection Agency (EPA) Superfund sites (Eagle Harbor, Harbor Island, Commencement Bay, and Sinclair Inlet sites) (Swartz and others, 1982; Malins and others, 1984; McCain and others, 1990; Puget Sound Water Quality Authority, 1995; Stein and others, 1995). Additional marine sampling has been conducted by the National Oceanic and Atmospheric Administration's (NOAA) Office of Marine Pollution Assessment, which has examined fish abnormalities such as hepatic lesions and hepatocellular nuclear pleomorphisms (National Oceanic and Atmospheric Administration, 1980). Historically, many of the rivers flowing to Puget Sound were conduits for 
treated- and, in some cases, untreated-industrial and municipal waste. More recently, most of the industrial and municipal wastewater treatment plants discharge directly to Puget Sound. The two potential sources of contamination (river discharge and Puget Sound direct-discharge) make it difficult to identify the source of any contaminants found in the marine fish and shellfish today, particularly for some of the more stable and persistent compounds. However, in most cases the historical and current disposal of municipal waste and industrial waste along Puget Sound probably accounts for most of the concentrations of organic and inorganic compounds in fish and shellfish.

Prior to the U.S. Geological Survey's Puget Sound Basin NAWQA tissue survey in 1995, no known freshwater tissue monitoring program or survey existed with a spatial coverage comparable to the monitoring of the marine environment performed by PSAMP. In 1992, the U.S. Environmental Protection Agency prepared a National Sediment Inventory data base that contained tissue data collected by various local, state and federal agencies from across the United States (U.S. Environmental Protection Agency, 1994). Of the 56 tissue sampling sites in the Puget Sound Basin in the EPA data base, 9 freshwater sites were sampled for both trace elements and synthetic organic compounds, and 1 site was sampled for synthetic organic compounds (fig. 12). The ranges of contaminant concentrations observed at each site are summarized in Appendixes A and B. From the EPA data base, in many cases, it was difficult or impossible to determine the sampling methods, analytical methods and detection limits, or quality assurance procedures employed at any one site or for any one constituent due to inconsistencies in the remarks associated with the data. However, the range of freshwater fish tissue concentrations, as recorded in the EPA data base, provides a basis on which to compare future tissue concentration data as well as identify potential areas of concern.

An additional source of freshwater fish tissue data within the Puget Sound Basin was collected as part of the Washington State Pesticide Monitoring Program (WSPMP) (Davis and Johnson, 1994). Only one site from the 1992 study, Mercer Slough, is located within the Puget Sound Basin (fig. 12; Appendix B). While the list of constituents sampled for was smaller than many of the sites in the EPA data base, the methods and quality control procedures for this data have been clearly documented (Davis and Johnson, 1994).

Tissue-contamination data for freshwater aquatic biota within the streams and rivers of the Puget Sound Basin are mostly of fish. The data from the EPA data base and the WSPMP are limited to either whole body or selected organ samples from five species of fish: bridgelip sucker (Catostomus columbianus), mountain whitefish (Prosopium williamsoni), northern squawfish (Ptychocheilus oregonensis), rainbow trout (Oncorhynchus mykiss) and largescale sucker (Catostomus macrocheilus). Generally, contaminant concentrations in bottom species, such as bridgelip and largescale suckers, were larger than in the other species examined. Concentrations of organochlorine compounds in whole fish were generally higher than in fish fillet samples because muscle tissue typically contains lower concentrations of lipids in which contaminants tend to bioaccumulate (Schmitt and others, 1981).

Contaminant concentrations from the EPA data base and the Washington State Pesticide Monitoring Program were compared to the geometric mean and maximum values of compounds examined in the U.S. Fish and Wildlife Services's (USFWS) 1980-81 and 1984 National Contaminant Biomonitoring Program (NCBP) studies (Schmitt and Brumbaugh, 1990; Schmitt and others, 1990). The NCBP has determined the concentrations of a selected number of trace elements and organochlorine chemicals in samples of fish collected from a nationwide network of stations. While the geometric mean and maximum concentrations from this monitoring program do not constitute target criteria, they do provide a baseline with which to compare Puget Sound Basin tissue samples. In addition, the National Academy of Sciences and National Academy of Engineering (1973) criteria and the New York State Department of Environmental Conservation (NYSDEC) criteria (Newell and others, 1987) for the protection of predatory fish and wildlife were used to assess selected organochlorine concentration in tissue. Contaminant concentration associated with adverse biological effects reported in toxicity studies were also used to evaluate the status of contaminant concentrations in fish tissue within the freshwaters of the Puget Sound Basin.

\section{Trace Elements}

Many trace elements occur naturally in both the environment and the tissues of aquatic organisms. In natural systems, trace elements are redistributed by geological and biological cycles. Weathering processes transport these elements to nearby streams and lakes, where they are either transported downstream or taken up by plants and animals. The abundance and distribution of trace elements can be altered by anthropogenic factors such as mining, smelting, finishing and plating of metals, paint and dye manufacturing, automobile emissions, agricultural 


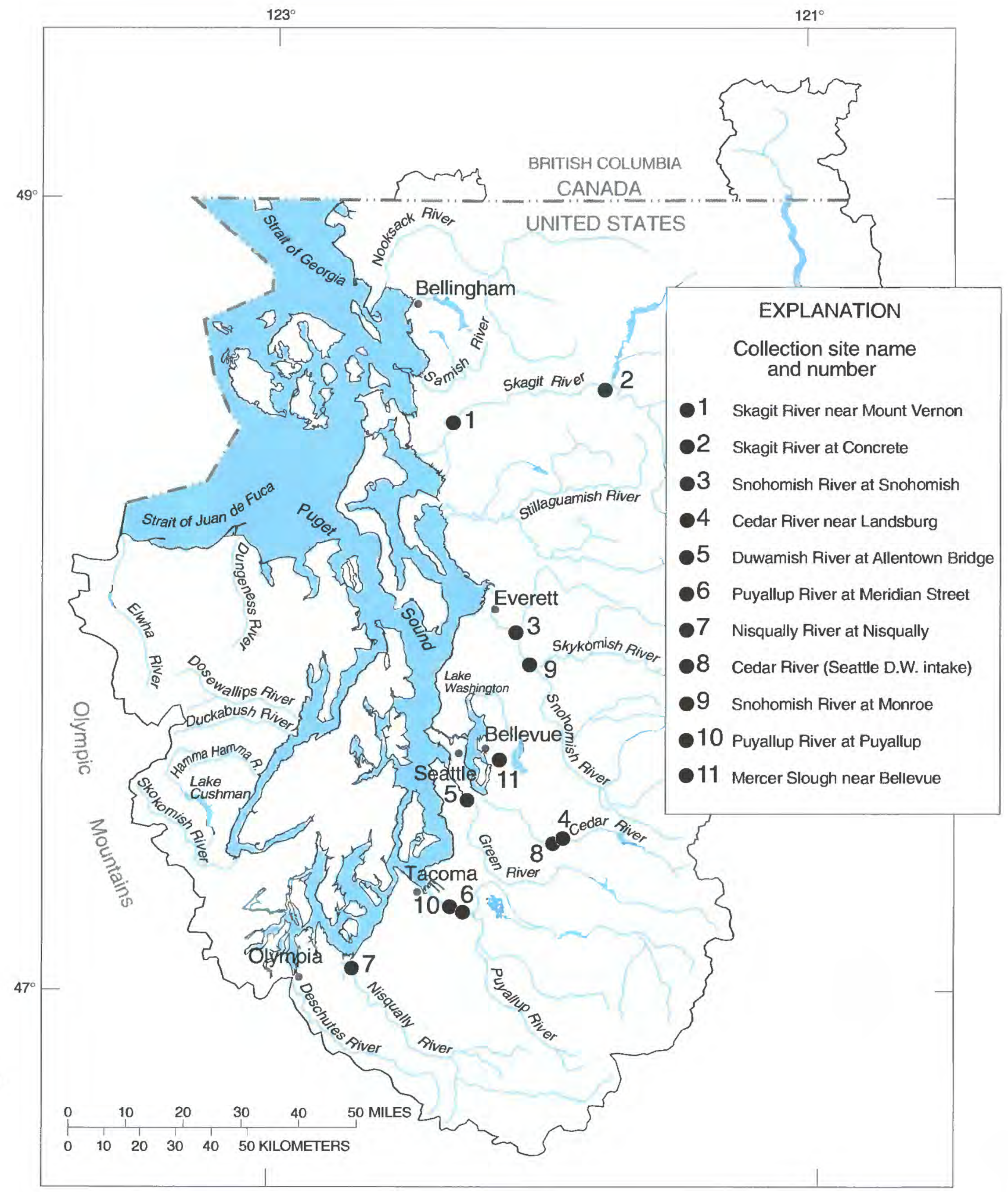

Figure 12. Fish tissue collection sites in Puget Sound Basin streams. 
pesticide and fertilizers, and other industrial activities. Contamination may also occur through contact with domestic pipes and storage tanks (Rand and others, 1995).

In aquatic systems, the trace elements of greatest concern are copper, zinc, cadmium, mercury, and lead (Rand and others, 1995). These elements can be extremely toxic to aquatic organisms above specific threshold concentrations. However, some trace elements, such as copper and zinc, are essential to animal and plant nutrition, but can still be toxic at high concentrations. Other compounds of concern include aluminum, chromium, selenium, silver, arsenic, and antimony, which have all been found to affect aquatic systems (Rand and others, 1995). In all cases, these elements can affect multiple organs of aquatic plants and animals by modifying critical biochemical pathways (Goyer, 1986).

As noted previously, PSAMP, as well as many other public and private groups, has collected a large number of tissue samples from the bays and estuaries of Puget Sound. Within the EPA's National Sediment Inventory data base, more than 50 sites were sampled for fish or invertebrate tissue, and more than 20 species of fish or invertebrates were examined. Of these sites, only nine trace element fish tissue sampling sites were located in the freshwater rivers of Puget Sound (fig. 12), and only four species of fish were examined at these sites. The most abundant fish examined was the bridgelip sucker, which accounted for approximately 50 percent of the tissue samples examined at the freshwater sites. The mountain whitefish and northern squawfish accounted for 30 percent and 10 percent of the freshwater tissue samples, respectively. The only game fish examined was the rainbow trout which accounted for 10 percent of the trace element samples.
At six of the nine freshwater sites examined for trace elements in fish tissue, two species of fish were collected simultaneously. Bridgelip suckers and mountain whitefish were collected simultaneously at the following sites: the Skagit River near Mount Vernon (1982 and 1984), the Skagit River at Concrete (1983), the Nisqually River at Nisqually (1982), and the Puyallup River at Puyallup (1984) (fig. 12). Generally, trace element concentrations were slightly higher for all constituents, except zinc, in the bridgelip sucker taken from all of these sites. At the Snohomish River at Snohomish and Duwamish River at the Allentown Bridge sites, bridgelip sucker and northern squawfish were collected. A general trend in trace element concentrations in these two species of fish was not well defined.

Generally, the range of concentrations of cadmium, copper, and lead exceeded the nationwide mean concentrations (fig. 13; table 4). The highest concentration of lead was found in a rainbow trout sampled in the Cedar River near the Seattle drinking-water intake (fig. 13). Only one fish was sampled, and the tissue concentration for lead was $2.4 \mu \mathrm{g} / \mathrm{g}$. This is well above the maximum level of $0.3 \mu \mathrm{g} / \mathrm{g}$ and $2.0 \mu \mathrm{g} / \mathrm{g}$ suggested for the protection of humans consuming fish in the United States and Great Britain, respectively (Schmitt and others, 1984; Maddock and Taylor, 1980). It was also greater than the maximum and mean lead concentration observed in the nationwide baseline study in 1980-81 and 1984, respectively (table 4). However, the EPA data base did not indicate whether or not the tissue sample for this trout was taken from a whole body, a specific organ, or a fillet, which would influence its toxicity to humans. Copper concentrations were highest in northern squawfish collected at the Duwamish River site, which is the most urbanized of the sites (fig. 13). The

Table 4.--Geometric mean and maximum concentrations of trace elements in fish tissues collected for the U.S. Fish and Wildlife Service National Contaminant Biomonitoring Program, 1980-81 and 1984

[Source: Schmitt and Brumbaugh, 1990; Schmitt and others, 1990]

\begin{tabular}{|c|c|c|c|c|}
\hline \multirow[b]{3}{*}{ Constituent } & \multicolumn{4}{|c|}{ Concentrations in micrograms per gram (wet weight) } \\
\hline & \multicolumn{2}{|c|}{$1980-81^{*}$} & \multicolumn{2}{|c|}{ 1984* } \\
\hline & Mean & Maximum & Mean & Maximum \\
\hline Arsenic & 0.14 & 1.69 & 0.14 & 1.50 \\
\hline Cadmium & 0.03 & 0.35 & 0.03 & 0.22 \\
\hline Copper & 0.68 & 24.10 & 0.65 & 23.10 \\
\hline Lead & 0.17 & 1.94 & 0.11 & 4.88 \\
\hline Mercury & 0.11 & 0.77 & 0.10 & 0.37 \\
\hline Selenium & 0.47 & 2.47 & 0.42 & 2.30 \\
\hline Zinc & 23.82 & 109.20 & 21.70 & 118.40 \\
\hline
\end{tabular}



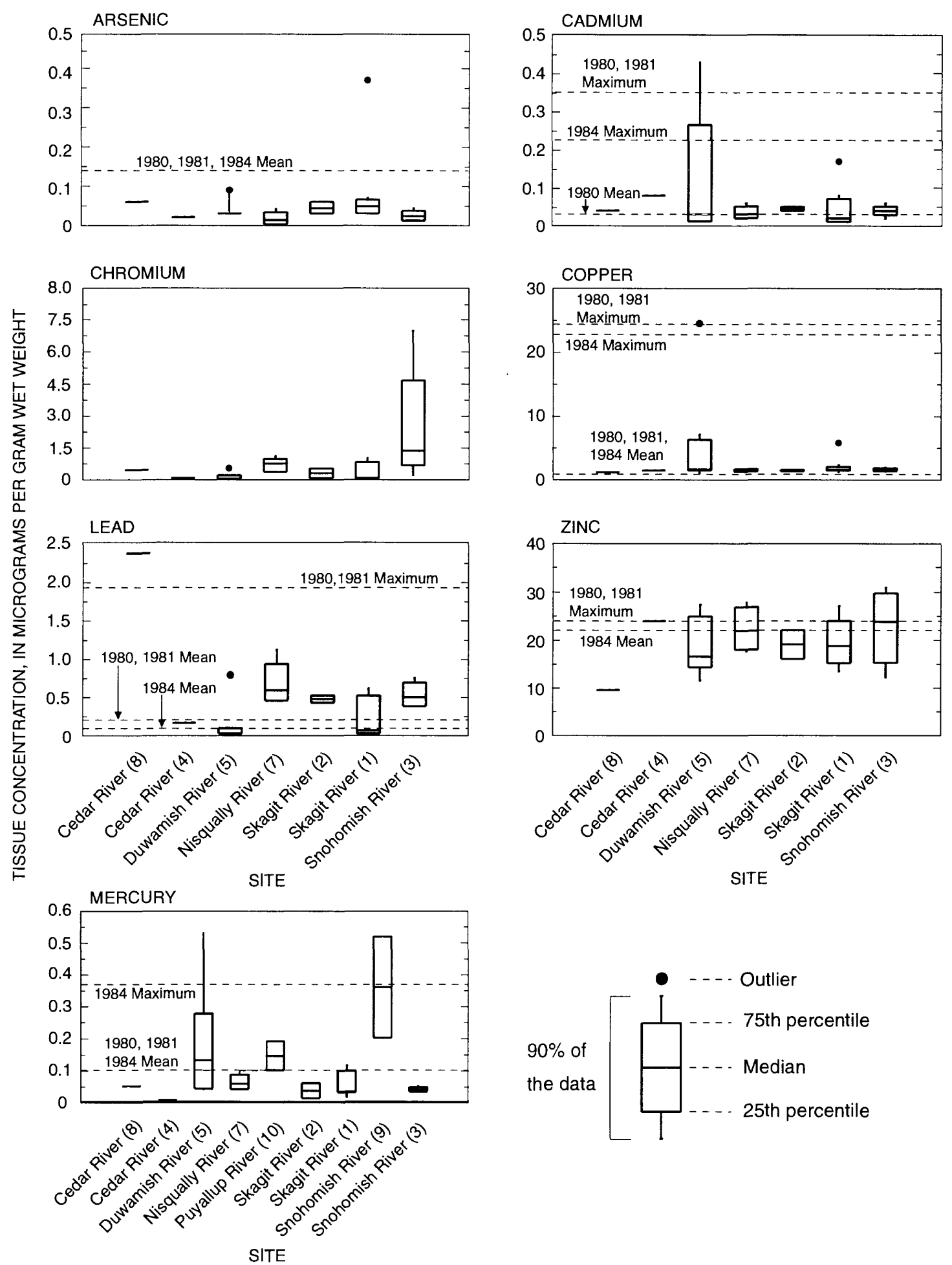

Figure 13. Summary of trace element concentrations in the tissue of fish collected by various agencies from selected sites in the Puget Sound Basin, 1980-84. The number following each site name corresponds to Figure 12. Dashed lines identify the national maximum and mean values for specific compounds by year. (From Schmitt and $\mathrm{Br}$.mbaugh,1990, and Schmitt and others, 1990. Data from United States Environmental Protection Agency, 1994.) 
concentration of copper in one of three fish sampled at this site was $24.6 \mu \mathrm{g} / \mathrm{g}$, which is above the maximum concentration found in the national studies (fig. 13; table 4). Cadmium concentrations were also the highest in northern squawfish collected in the Duwamish River in 1984. The maximum cadmium tissue concentration at this site was $0.43 \mu \mathrm{g} / \mathrm{g}$, above the maximum value observed in both the national baseline studies (fig. 13; table 4).

The highest mercury concentration at the Snohomish River at Monroe site (fig. 13) was above the maximum and mean value recorded in the national baseline study in 1984 and $1980-81$, respectively. A value of $0.52 \mu \mathrm{g} / \mathrm{g}$ was recorded in a bridgelip sucker at this site. To protect human health, mercury concentrations in consumed fish are not to exceed $0.25 \mu \mathrm{g} / \mathrm{g}$ for expectant mothers (Khera, 1979). However, it is unclear if bridgelip sucker are consumed by humans in Puget Sound Basin or if the tissue sample was a whole fish or a fillet. By comparison, mercury concentrations are not to exceed $0.10 \mu \mathrm{g} / \mathrm{g}$ to protect sensitive species of fish-eating birds (Heinz, 1979; March and others, 1983). Mercury concentrations were well above this value at the Duwamish, Puyallup, Skagit and Snohomish River sites (fig. 13). Zinc concentrations in northern squawfish were $30.9 \mu \mathrm{g} / \mathrm{g}$ at the Snohomish River at Snohomish site, above the national baseline average (fig. 13; table 4).

The highest concentration of arsenic was observed in bridgelip suckers sampled at the Skagit River near Mount Vernon site in 1984. The concentration of $0.37 \mu \mathrm{g} / \mathrm{g}$ was above the national baseline mean for arsenic, but below the $0.5 \mu \mathrm{g} / \mathrm{g}$ concentration viewed as harmful to fisheating predators (fig. 13) (Walsh and others, 1977). A chromium concentration of $7.0 \mu \mathrm{g} / \mathrm{g}$ was observed in a bridgelip sucker sampled at the Snohomish River at Snohomish site (fig. 13). According to Eisler (1986), tissues of fish that contain more than $4.0 \mu \mathrm{g} / \mathrm{g}$ of chromium (dry weight) should be viewed as contaminated.

\section{Synthetic Organic Compounds}

Large-scale use of manufactured organic chemicals in industrial and domestic applications and products has increased both direct and indirect discharge to aquatic environments. While the fate of organic compounds varies, many of them adsorb on suspended particles that are deposited along the stream bottom, where aquatic organisms can be exposed to them. Bioavailability and toxicity characteristics vary widely, both within and between various groups of organic chemicals. Some chemicals of concern include PCB's, polycyclic aromatic hydrocarbons (PAH), and pesticides such as DDT. Because of their chemical stability, PCB's were widely used in numerous industrial processes (Rand and others, 1995). However, it was the stability and the bioaccumulation and toxic properties of PCB's that resulted in their discontinued use in 1970 (U.S. Environmental Protection Agency, 1989). Polycyclic aromatic hyrdocarbons can be either natural products or human-made compounds. The human-made products dominate the environment and can cause mutations and cancers in aquatic biota. Polycyclic aromatic hydrocarbons can come from municipal and industrial effluents, petroleum spills, combustion of fossil fuels, and brush and forest fires (Rand and others, 1995). DDT is a cheap, effective insecticide that is still used in many countries other than the United States. DDT can bioaccumulate in animals through the food chain and can be toxic to aquatic organisms (Pimental, 1971; Moriarty, 1988). Like PCB's, DDT is expected to remain in the tissue of aquatic organisms in the foreseeable future, although their use was discontinued in the United States in 1972 (U.S. Environmental Protection Agency, 1992).

The EPA's National Sediment Inventory data base contains 10 sites within Puget Sound Basin that were sampled for synthetic organic compounds in fish tissue (fig. 12; Appendix B). Five different species of fish were sampled for organic compounds: bridgelip sucker (44 percent), mountain whitefish (26 percent), rainbow trout (16 percent), northern squawfish (10 percent) and largescale sucker (4 percent). In 1992, the Washington State Department of Ecology sampled one freshwater site within Puget Sound Basin for synthetic organic compounds in largescale sucker and rainbow trout (Davis and Johnson, 1994).

At 7 of the 11 freshwater sites examined for synthetic organic compounds, 2 species of fish were collected simultaneously, bridgelip suckers and mountain whitefish, at the following sites: the Skagit River near Mount Vernon (1982 and 1984), the Skagit River at Concrete (1983), the Nisqually River at Nisqually (1982), and the Puyallup River at Puyallup (1984) (fig. 12). At the Snohomish River at Snohomish and Duwamish River at the Allentown Bridge sites, bridgelip sucker and northern squawfish were collected simultaneously. Largescale sucker and rainbow trout were simultaneously sampled at the Mercer Slough site (fig. 12). From a comparison of bridgelip sucker and mountain whitefish or bridgelip sucker and northern squawfish tissue concentrations, there did not appear to be any differential uptake of organic compounds among the species. However, at Mercer 
Slough, tissue concentrations of organic compounds were consistently higher in largescale sucker than in rainbow trout.

Generally, concentrations of synthetic organic compounds in fish tissues at the 11 sites sampled were below national averages (table 5; Appendix B). In addition, most of the sites were also below the National Academy of Sciences and National Academy of Engineering (NASNAE) (1973) guidelines and the New York State Department of Environmental Conservation (NYSDEC) (Newell and others, 1987) fish flesh criteria for the protection of predatory fish and wildlife. The NAS-NAE guidelines state that (1) aldrin, BHC, chlordane, dieldrin, endosulfan, endrin, heptachlor, heptachlor epoxide, lindane, and toxaphene, either singly or in combinations should not exceed $0.1 \mu \mathrm{g} / \mathrm{g}$, wet weight and (2) DDT and any or all of its metabolites should not exceed $1.0 \mu \mathrm{g} / \mathrm{g}$, wet weight. The NYSDEC criteria state that the following compounds should not exceed the identified concentration in wet weight: (1) aldrin plus dieldrin, $0.12 \mu \mathrm{g} / \mathrm{g}$; (2) heptachlor plus heptachlor epoxide, $0.2 \mu \mathrm{g} / \mathrm{g}$; (3) total chlordane, or cis chlordane, or trans chlordane, $0.5 \mu \mathrm{g} / \mathrm{g}$; (4) total $\mathrm{HCH}$ or lindane, $0.1 \mu \mathrm{g} / \mathrm{g}$; (5) hexachlorobenzene or mirex, $0.33 \mu \mathrm{g} / \mathrm{g}$; (6) endrin, $0.025 \mu \mathrm{g} / \mathrm{g}$; (7) total PCB, $0.11 \mu \mathrm{g} / \mathrm{g}$; and (8) DDT and any or all of its metabolites, $0.2 \mu \mathrm{g} / \mathrm{g}$. While the NAS-NAE guidelines and the NYSDEC criteria are different, both should be considered in the evaluation of fish tissue contamination. However, the NYSDEC criteria are based on more extensive laboratory studies similar to those used to derive criteria for protection of human health.

A number of elevated levels of selected synthetic organic compounds were detected at a number of sites (table 6). In 1983, at the Duwamish River at the Allentown Bridge site, BHC (alpha) and PCB (1254) concentrations were above the national averages for these compounds (table 5). In addition, PCB (1254) exceeded the NYSDEC criteria for the protection of predatory fish and wildlife (Newell and others, 1987). In 1984, mean BHC (alpha), $p, p^{\prime}$ DDD, $p, p^{\prime}$ DDE, $p, p^{\prime}$ DDT, total DDT and $\mathrm{PCB}(1260)$ concentrations were above the national averages for these compounds. The maximum PCB (1260), $o, p^{\prime} \mathrm{DDT}, o, p^{\prime} \mathrm{DDE}, p, p^{\prime} \mathrm{DDD}, p, p^{\prime} \mathrm{DDT}$, $p, p$ ' DDE, and total DDT concentrations also exceeded the NYSDEC criteria for the protection of predatory fish and wildlife (Newell and others, 1987). Three additional sites had mean tissue concentrations above the national averages. The Skagit River at Mt. Vernon site had elevated levels of $p, p$ ' DDT. Maximum concentrations of total DDT were also above the NYSDEC criteria for this site. The Mercer Slough site had elevated levels of PCB
(1260). In addition, maximum concentrations of PCB (1260), total PCB's, and total DDT were above the NYSDEC criteria. The Snohomish River at Snohomish site had elevated levels of PCB (1254) and the minimum, mean, and maximum levels of this compound were all above the NYSDEC criteria (table 6). Two additional sites, Puyallup River at Meridian Street Bridge and Snohomish River at Monroe, both had total PCB concentrations above the NYSDEC criteria (table 6).

There is an abundance of tissue data for fish and invertebrates collected in the waters of Puget Sound, but tissue data for fish and invertebrates from streams and rivers are limited. As a result, any definitive conclusions pertaining to the status of tissue concentrations and biological health are difficult to make. Tissue concentrations of some trace elements and synthetic organic compounds were higher than national averages and some criteria based on the limited data set examined. However, concentrations were not exceedingly high at any location and, therefore, may not be a significant problem in the streams of Puget Sound Basin.

\section{SUMMARY}

The assessment of biological resources is an integral component of the NAWQA program. Evaluating aquatic community composition and habitat conditions, as well as concentrations of selected analytes in tissues of aquatic organisms, helps to evaluate and assess spatial and temporal trends in water quality (Gurtz, 1994). The examination of the biological attributes of a stream or river can provide an index of trends in water quality often missed by periodic chemical analyses or physical measurements of water or sediment. Biological monitoring also provides an ideal method for evaluating improvements to aquatic systems from restoration or pollution abatement programs.

The water within the streams and rivers of Puget Sound Basin is generally of good quality (Staubitz and others, 1996). However, throughout the basin, there are a number of historical and current anthropogenic effects on the overall quality of the streams and rivers. The Puget Sound Lowland streams are affected by two major land uses: urbanization and agriculture. Both land uses affect the biological conditions of the streams and rivers of the basin by either adding chemicals or physically disturbing streams and rivers. Chemical additions are attributed to point-source discharges of waste or nonpoint sources of runoff. Most point source discharges to Puget Sound Basin are made to the salt waters of Puget Sound. 


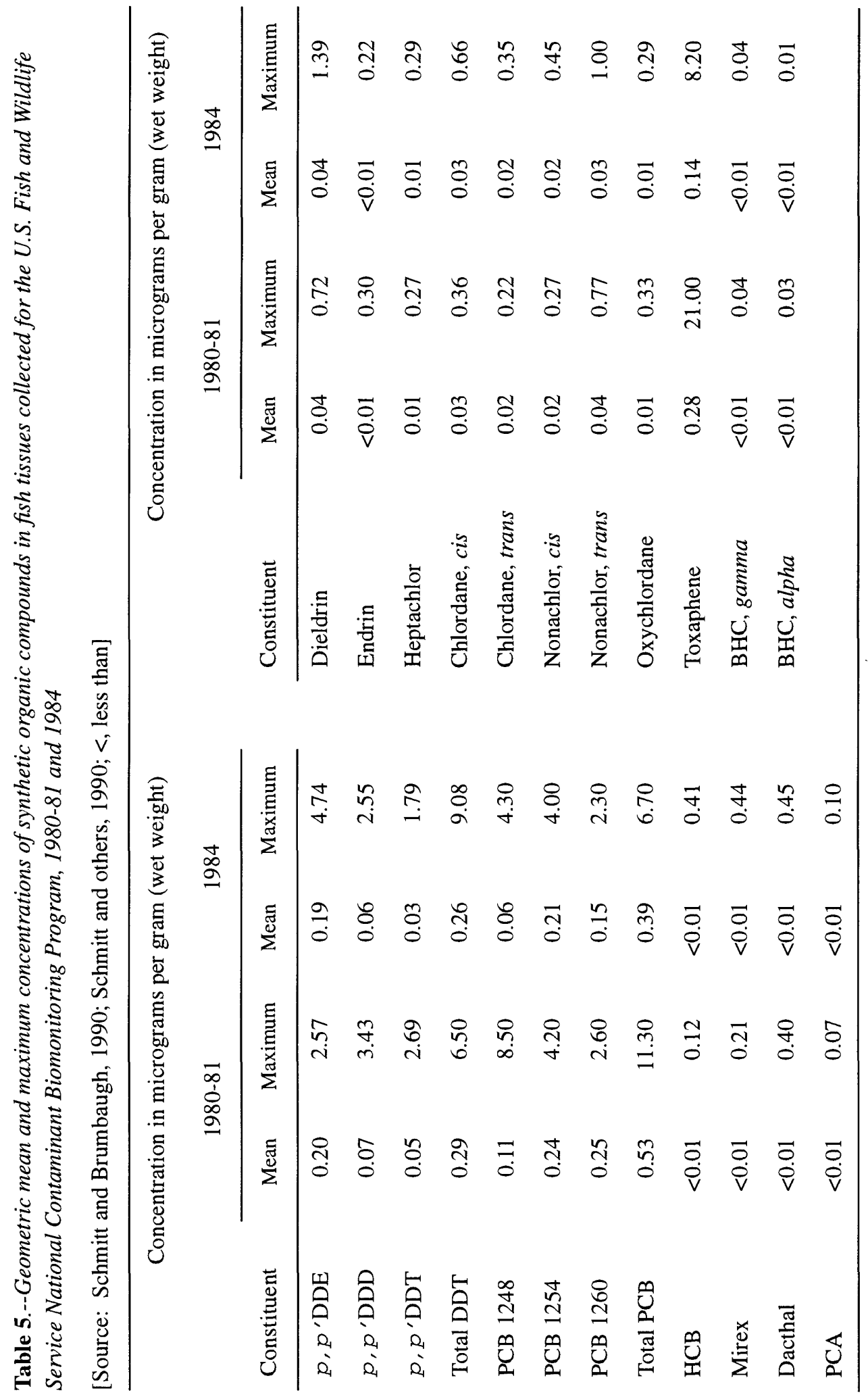


Table 6.--Summary of elevated synthetic organic compound concentrations in tissue of fish collected by various agencies from selected sites in the Puget Sound Basin, 1980-92

[All concentrations are in micrograms per gram (wet weight); entries in bold typeface are greater than the national baseline geometric mean or maximum for that compound (See table 5); samples collected between 1980 and 1983 were compared to the national baseline data collected in 1980 and 1981; samples collected between 1984 and 1992 were compared to the 1984 national baseline data set; *, indicates a tissue sample greater than the National Academy of Sciences/National Academy of Engineering recommended maximum tissue concentrations; + , a tissue sample greater than the New York Department of Environmental Conservation fish flesh criteria; , analyte was positively identified, but the value is an estimate (Davis and Johnson, 1994; U.S. Environmental Protection Agency, 1994)]

\begin{tabular}{|c|c|c|c|c|c|c|}
\hline $\begin{array}{l}\text { Site number } \\
\text { (figure 12) }\end{array}$ & Location and organic compound sampled & Date & $\begin{array}{c}\text { Number } \\
\text { of } \\
\text { samples }\end{array}$ & $\begin{array}{l}\text { Mini- } \\
\text { mum }\end{array}$ & Mean & $\begin{array}{l}\text { Maxi- } \\
\text { mum }\end{array}$ \\
\hline \multirow[t]{3}{*}{1} & SKAGIT RIVER NEAR MOUNT VERNON & & & & & \\
\hline & $p, p^{\prime} \mathrm{DDT}$ & 1984 & 3 & 0.019 & 0.055 & 0.100 \\
\hline & TOTAL DDT & 1984 & 4 & 0.064 & 0.188 & $0.369+$ \\
\hline \multirow[t]{2}{*}{3} & SNOHOMISH RIVER AT SNOHOMISH & & & & & \\
\hline & PCB -1254 & 1982 & 2 & $0.240+$ & $0.280+$ & $0.320+$ \\
\hline \multirow[t]{11}{*}{5} & $\begin{array}{l}\text { DUWAMISH RIVER AT ALLENTOWN } \\
\text { BRIDGE }\end{array}$ & & & & & \\
\hline & BHC-ALPFA & 1983 & 1 & 0.020 & 0.020 & 0.020 \\
\hline & PCB - 1254 & 1983 & 1 & $1.600+$ & $1.600+$ & $1.600+$ \\
\hline & BHC-ALPHA & 1984 & 4 & 0.059 & $0.228 *$ & $0.460^{*}$ \\
\hline & $o, p^{\prime} \mathrm{DDT}$ & 1984 & 4 & 0.073 & 0.191 & $0.330+$ \\
\hline & $o, p^{\prime} \mathrm{DDE}$ & 1984 & 4 & 0.120 & 0.185 & $0.250+$ \\
\hline & $p, p^{\prime} \mathrm{DDD}$ & 1984 & 4 & 0.160 & $0.265+$ & $0.340+$ \\
\hline & $p, p^{\prime} \mathrm{DDT}$ & 1984 & 4 & $0.300+$ & $0.508+$ & $0.970+$ \\
\hline & $p, p$ ' DDE & 1984 & 4 & 0.160 & 0.428 & $0.630+$ \\
\hline & TOTAL DDT & 1984 & 4 & $0.813+$ & $1.577 *_{+}$ & $2.520 *+$ \\
\hline & PCB - 1260 & 1984 & 4 & $0.420+$ & $0.593+$ & $0.760+$ \\
\hline \multirow[t]{3}{*}{6} & $\begin{array}{l}\text { PUYALLUP RIVER AT MERIDIAN ST. } \\
\text { BRIDGE }\end{array}$ & & & & & \\
\hline & PCB-TOTAL & 1980 & 1 & $0.290+$ & $0.290+$ & $0.290+$ \\
\hline & PCB-TOTAL & 1981 & 1 & $0.160+$ & $0.160+$ & $0.160+$ \\
\hline \multirow[t]{2}{*}{9} & SNOHOMISH AT MONROE & & & & & \\
\hline & PCB-TOTAL & 1984 & 1 & $0.206+$ & $0.206+$ & $0.206+$ \\
\hline \multirow[t]{4}{*}{11} & MERCER SOULGH NEAR BELLEVUE & & & & & \\
\hline & TOTAL DDT & 1992 & 2 & 0.023 & 0.136 & $0.249+$ \\
\hline & PCB - 1260 & 1992 & 2 & $0.031 \sim$ & $0.153+$ & $0.275+$ \\
\hline & PCB-TOTAL & 1992 & 2 & 0.051 & $0.215+$ & $0.379+$ \\
\hline
\end{tabular}


Therefore, nonpoint sources have a greater impact on the freshwater systems of the basin. Examples of nonpoint sources include urban runoff, seepage from septic systems, washoff from land of applied manure, fertilizers, or pesticides, and deposition from atmospheric sources.

Elevated concentrations of trace elements and synthetic organic compounds have been observed in fish tissues sampled in the Puget Sound Lowlands. Most of the tissue sampling in Puget Sound Basin is done in the salt waters of Puget Sound. Only a small number of sites in a limited number of data bases is available for tissue samples from aquatic organisms. On the basis of the limited amount of data, trace elements such as cadmium, copper, lead, and mercury were found at elevated concentrations in the fish tissues examined, compared with USFWS national means (Schmitt and Brumbaugh, 1990; Schmitt and others, 1990). However, only one fish tissue sample collected from the Snohomish River near Monroe had concentrations of mercury in excess of human health and fish and wildlife health recommendations (Khera, 1979; Heinz, 1979; March and others, 1983).

Synthetic organic compounds in fish tissue were generally below national means (Schmitt and Brumbaugh, 1990; Schmitt and others, 1990). However, concentrations of some PCB alochlor and DDT derivatives were above national means at the Skagit River near Mt. Vernon, Mercer Slough, and Duwamish River at the Allentown Bridge sites. Tissue samples collected at the Duwamish River at Allentown Bridge, Skagit River near Mount Vernon, Snohomish River at Snohomish, Snohomish River at Monroe, Puyallup River at Meridian Street Bridge, and Mercer Slough near Bellevue sites all had one or more compounds above the NAS-NAE and/or the NYSDEC guidelines for the protection of fish eating wildlife.

The upland ecoregions (Coast Range, Cascades, and North Cascades) are largely composed of uninhabited, forested, mountainous terrain. The chemical quality of surface water in the upland ecoregions is generally very good and is usually suitable for most uses (Staubitz and others, 1997).

In addition to chemical perturbations, extensive physical modification of many streams in the basin has altered their structure and function from historical levels. The Puget Sound Lowlands have undergone significant changes in their structure and function since settlement of the Pacific Northwest, by natural events such as floods, wildfires, and windstorms. Recent human activities within the basin have tended to simplify stream systems and reduce or eliminate the natural disturbances that create and maintain the habitat complexity necessary to maintain healthy biological systems. Habitat degradation is a common problem in urban areas (King County Surface Water Management Division, 1993). In the main stem of the Cedar River, it is estimated that fish habitat has been reduced by approximately 56 percent because of water supply dams, land development, levees, bank revetments, and removal of large woody debris. In the last 80 years, water diversions and flood control activities changed the once-braided channels of the lower main stem of the Cedar River to a single-reach channel (King County Surface Water Management Division, 1993). Similar effects have been observed in many of the large lowland rivers, particularly near the mouths of rivers (Bortleson and others, 1980). The physical changes in these streams are reflected in the changes in the aquatic biota such as fish and aquatic invertebrates (Washington State Department of Fish and Wildlife and others, 1993; King County Department of Metropolitan Services, 1994b).

Streams in the upland ecoregions (Coast Range, Cascades, and North Cascades) have also been influenced by physical disturbances such as forest harvesting and associated road building. These activities, in addition to other human perturbations, have had the greatest effect on the structure and function of streams and rivers in these ecoregions. The effects on streamflow and water quality from logging depend on a number of factors such as percentage of a basin cut, method of harvest, road maintenance, forest chemical applications, and proximity to streams, wetlands, and shorelines. Principal water-quality concerns from logging are erosion of soils that cause increased sediment transport to streams; removal of the forest canopy near streams that causes elevated stream temperatures; increased nutrient yields following harvest; and application of forest chemicals, causing toxicity to aquatic biota. Most studies have discussed clear-cut logging and road construction in the mountains as potentially contributing to sediment transport and increased peak flows (Harr, 1986; MacDonald and others, 1991), but it is often difficult to measure some of these effects, particularly sediment loads (Richardson, 1965; MacDonald and others, 1991; Washington Forest Practices Board, 1994; U.S. Forest Service, 1995a; U.S. Forest Service, 1995b).

Increases in stream temperatures after logging are well documented for small watersheds $(<1,000$ acres $)$, according to Anderson (1973). Stream temperature effects are particularly significant if logging extends into the riparian zone. Stream temperatures of small watersheds increase for 3 to 5 years following logging and return to pre-logging levels within 5 to 10 years (Harr and Fredrickson, 1988). The cumulative effects of logging on 
larger streams (streams with more than a $100-\mathrm{mi}^{2}$ drainage area) is less clear because their watersheds are cut by parcels over a long period. Paul (1996) reports that the variability in climate and hydrology over 5 to 10 years may mask the temperature trends of logging within these larger watersheds.

The physical condition of streams and rivers in Puget Sound Basin has dramatically changed since humans settled in the basin. While in-stream and riparian habitats play a critical role in the structure and function of aquatic systems, few studies have summarized habitat conditions within Puget Sound Basin as a whole (Ralph and others, 1991; Ralph and others, 1994), which is surprising, given the amount of habitat data available. A number of combined habitat data sets did reveal that the quality of instream woody debris in many of the Puget Sound Basin streams is well below the levels found in old-growth forests. This trend was observed in all of the ecoregions in the basin, particularly the Coast Range and Cascades ecoregions. A reduction in woody debris reduces the abundance of aquatic habitat for numerous aquatic organisms and also reduces the abundance of pools. A reduction in the number of pools, compared with historical numbers in the streams and rivers of Puget Sound Basin, was identified in a study performed by the U.S. Forest Service (1993). In some locations (Hood Canal streams), pools were entirely absent in long stretches of a river.

The past and present physical and chemical changes to streams in Puget Sound Basin have had an effect on aquatic riverine resources (Bisson and others, 1992). Over the last 100 years, the abundance of many stocks of salmon have significantly declined throughout the West, as well as the Puget Sound Basin (Nehlsen and others, 1991; The Wilderness Society, 1993; Washington Department of Fish and Wildlife and Western Washington Treaty Indian Tribes, 1993; 1994). The health of most stocks of salmon within the basin has declined. The sockeye stock is particularly depressed. The number of fish within each stock are reduced, and the size and age of many returning salmon are also below historical values (Fraidenburg and Lincoln, 1985; Gall, 1991; Beatty, 1992). Little data exist on the abundance and distribution of fish other than salmon (Bisson and others, 1991; Mongillo and Hallock, 1995). In order to use fish as indicators of changes in water quality, a better understanding of the dynamics of resident fish populations is needed.

In addition to the importance of understanding fish communities, the examination of macroinvertebrate communities can also be an extremely valuable method for the assessment of water quality or biological integrity of a stream or river system, for a number of reasons: (1) macroinvertebrates are numerous, are found in many types of streams, and are exposed to numerous natural or anthropogenic disturbances; (2) there are numerous species, each with unique environmental requirements and tolerances; (3) they are fairly sedentary, which allows evaluation of spatial disturbances; and (4) they have a fairly long life cycle within a particular location, which allows evaluation of temporal trends in disturbance (Rosenberg and Resh, 1993). The combination of these factors makes macroinvertebrates ideal integrators of the effects of natural and anthropogenic disturbances over multiple temporal and spatial scales.

Although aquatic macroinvertebrates represent an ideal biological indicator of changes in water quality and biological integrity, only a limited number of studies have examined invertebrate communities across a broad spatial scale to assess water quality within Puget Sound Basin (Municipality of Metropolitan Seattle, 1977; Brenner and Morrice, 1978; Plotnikoff, 1992; and Kleindl, 1995). Easily accessible invertebrate data are also limited. More recently, a comprehensive study of macroinvertebrates designed to assess the biological integrity of low-order northwestern streams was done in Puget Sound Lowlands (Kleindl, 1995). The use of biological attributes or metrics identified that increasing urbanization had a significantly greater effect on the composition of macroinvertebrate communities than did natural variability, representing a potential reduction in water quality and biological integrity (Kleindl, 1995).

\section{SELECTED REFERENCES}

The topical bibliography includes both primary and secondary sources of biotic and habitat information. Primary sources of information were identified as those references that met one or more of the following criteria: regional in their coverage of a topic, high quality source of numeric data for a topic, or seminal papers or reports summarizing the state of our understanding for a topic in relation to the Puget Sound Basin. Secondary sources of information were identified as those references that met one or more of the following criteria: reports specific to individual drainages, reports specific to the Puget Sound Basin with limited numeric data, or general seminal papers or reports for a topic. The references identified below are not intended to represent an exhaustive list, but rather a summary of available information for each topic. Many of the reports and papers were identified during the review of 
existing information, but were not identified as critical, based on the scope of the report. Not all of the references below are cited in the text of this report. However, all of the references cited in this report are included in this reference list.

\section{Fisheries}

\section{Primary Information Sources}

Bisson, P.A., Quinn, T.P., Reeves, G.H., and Gregory, S.V., 1992, Best management practices, cumulative effects, and long-term trends in fish abundance in Pacific Northwest river systems, in Naiman, R.J., ed., Watershed Management--Balancing Sustainability and Environmental Change: New York, Springer-Verlag, p. 189-232.

Bledsoe, L.J., Somerton, D.A., and Lynde, C.M., 1989, The Puget Sound runs of salmon--an examination of the changes in run size since 1896, in Levings, C.D., Holby, L.B., and Henderson, M.A., eds., Proceedings of the National Workshop on Effects of Habitat Alteration on Salmonid Stocks: Canadian Special Publication on Fisheries and Aquatic Sciences, v. 105 , p. $50-61$.

Kruckeberg, A., 1991, The natural history of Puget Sound, Washington: Seattle, Wash., University of Washington Press, 460 p.

Mongillo, P.E., and Hallock, M., 1995, Resident nongame fish investigations 1993-1994 report: Washington State Department of Fish and Wildlife, Fish Management Program, Inland Fish Division, Olympia, $78 \mathrm{p}$.

Naiman, R.J., Beechie, T.J., Benda, L.E., Berg, D.R., Bisson, P.A., MacDonald, L.H., O'Connor, M.D., Olson, P.L., and Steel, E.A., 1992, Fundamental elements of ecologically healthy watershed in the Pacific northwest coastal ecoregion, in Naiman, R.J., ed., Watershed Management--Balancing Sustainability and Environmental Change: New York, Springer Verlag, $542 \mathrm{p}$.

Nehlsen, W., Williams, J.E., and Lichatowich, J.A., 1991, Pacific salmon at the crossroads--stocks at risk from California, Oregon, Idaho, and Washington: Fisheries, v. 16, p. 4-21.
Nooksack Salmon Enhancement Association, 1995, Northwest Salmon Recovery Endowment: Bellingham, Wash., Nooksack Salmon Enhancement Association, $24 \mathrm{p}$.

Northwest Indian Fisheries Commission, 1996, NWIFC Web Page: Olympia, Wash., from URL http:// mako.nwifc.wa.gov, accessed May 21, 1996, HTML format.

Olympic National Park Service, 1995, Provisional Fish list for Olympic National Park, $4 \mathrm{p}$.

Scott, W.B., and Crossman, E.J., 1985, Freshwater fishes of Canada: Ottawa, Canada, The Byrant Press Limited, Fisheries Research Board of Canada Bulletin 184, 966 p.

Staubitz, W.W., Bortleson, G.C., Semans, S.D., Tesoriero, A.J., and Black, R.W., 1997, Water quality assessment of the Puget Sound Basin, Washington--environmental setting and its implications for water quality and aquatic biota: U.S. Geological Survey Water-Resources Investigations Report 97-4013, 76 p.

SSHIAP, 1995, Salmon and steelhead habitat inventory and assessment project--wild salmon stock restoration initiative: Northwest Indian Fisheries Commission, $8 \mathrm{p}$.

The Wilderness Society, 1993, The living landscape, volume 2, Pacific salmon and federal lands: The Wilderness Society, Bolle Center for Forest Ecosystem Management, Seattle Washington, 88 p.

Washington Department of Ecology, 1995, Draft--State of the Nooksack River Watershed: Washington Department of Ecology, Nooksack Initiative Office, Bellingham, Washington, $124 \mathrm{p}$.

Washington State Department of Fisheries, 1992, Salmon 2000 technical report, phase 2-Puget Sound, Washington coast and integrated planning: Olympia, Wash., Washington State Department of Fisheries, $339 \mathrm{p}$.

Washington Department of Fish and Wildlife and Western Washington Treaty Indian Tribes, 1993, 1992 Washington State salmon and steelhead stock inventory--summary: Olympia, Washington, $212 \mathrm{p}$. 
Washington State Department of Fish and Wildlife and Western Washington Treaty Indian Tribes, 1994, 1992 Washington State salmon and steelhead stock inventory, Appendix One and Appendix two: Olympia, Washington, $789 \mathrm{p}$.

Washington Department of Wildlife and Bonneville Power Administration, 1992, Washington rivers information system--resident and anadromous fish data (1:100,000 scale update): Final Report, 25 p.

Wydoski, R.S., and Whitney, R.R., 1979, Inland fishes of Washington: Seattle, Washington, University of Washington Press, 220 p.

\section{Secondary Information Sources}

Allee, B.J., 1974, Spatial requirements and behavioral interactions of juvenile coho salmon (Oncorhynchus kisutch) and steelhead trout (Salmo gairdneri): Washington Cooperative Fisheries Research Unit, University of Washington, Seattle, Washington, USA, $182 \mathrm{p}$.

Amberson, S., and Fortune, B., 1992, The Nisqually, a delta under fire: Underwater Naturalist, v. 21, p. $24-27$.

Angermeier, P.L., and Karr, J.R., 1984, Relationships between woody debris and fish habitat in a small warmwater stream: Transactions of the American Fisheries Society, v. 113, p. 716-726.

Beatty, R.E., 1992, Changes in size and age at maturity of Columbia River upriver bright fall chinook salmon (Oncorhynchus tshawytscha)_implications for stock fitness, commercial value and management: Corvallis, Oreg., Oregon State University, M.S. thesis, $270 \mathrm{p}$.

Beecher, H.A., Carleton, J.P., and Johnson, T.H., 1995, Utility of depth and velocity preferences for predicting steelhead parr distribution at different flows: Transactions of the American Fisheries Society, v. 124, p. 935-938.

Beecher, H.A., Dott, E.R., and Fernau, R.F., 1988, Fish species richness and stream order in Washington State streams: Environmental Biology of Fish, v. 22, p. 193-209.
Benda, L., Beechie, T.J., Wissmar, R.C., and Johnson, A., 1992, Morphology and evolution of salmonid habitats in a recently deglaciated river basin, Washington State, USA: Canadian Journal of Fisheries and Aquatic Science, v. 49, p. 1,246-1,256.

Bilby, R., 1985, Contributions of road surface sediment to a western Washington stream: Forest Science, v. 31, p. 827-838.

Bilby, R.E., and Bisson, P.A., 1992, Allochthonous versus autochthonous organic matter contributions to the trophic support of fish populations in clear cut and old growth forested streams: Canadian Journal of Fisheries and Aquatic Science, v. 49, p. 540-551.

Bilby, R.E., Fransen, B.R., and Bisson, P.A., 1996, Incorporation of nitrogen and carbon from spawning coho salmon into the trophic system of small streams--evidence from stable isotopes: Canadian Journal of Fisheries and Aquatic Science, v. 53, p. 164-173.

Bilby, R.E., and Ward, J.W., 1991, Characteristics and function of large woody debris in streams draining old growth clear cut, and second growth forests in southwestern Washington: Canadian Journal of Fisheries and Aquatic Science, v. 48, p. 2,499-2,508.

Bisson, P.A., Nielsen, J.L., and Ward, J.W., 1988, Summer production of Coho salmon stocked in Mount St. Helens streams 3-6 years after the 1980 eruption: Transactions of the American Fisheries Society, v. 117, p. $322-335$.

Bryant, M.D., 1983, The role and management of woody debris in west coast salmonid nursery streams: North American Journal of Fisheries Management, v. 3, p. 322-330.

Bustard, D.R., and Narver, D.W., 1975, Aspects of the winter ecology of juvenile coho salmon (Oncorhynchus kisutch) and steelhead trout (Salmo gairdneri): Journal of Fisheries Research Board of Canada, v. 32, p. 667-680.

Caldwell, B.A., and Hirschey, S., 1989, Green River fish habitat analysis using the instream flow incremental methodology: Water Resources Program, Washington Department of Ecology, 148 p. 
Cederholm, C.J., Houston, D.B., Cole, D.L., and Scarlett, W.J., 1989, Fate of coho salmon (Oncorhynchus kisutch) carcasses in spawning streams: Canadian Journal of Fisheries and Aquatic Science, v. 46, p. $1,347-1,355$.

Cederholm, C.J., 1972, Short term physical and biological effects of stream channelization at Big Beef Creek, Kitsap County, Washington: Washington Cooperative Fisheries Research Unit, University of Washington, Seattle, Washington, USA, 91 p.

Cederholm, C.J., and Koski, K.V., 1977, Effects of stream channelization on the salmonid habitat and populations of lower Big Beef Creek, Kitsap County, Washington 1969-73: Washington Cooperative Fisheries Research Unit, University of Washington, Seattle, Washington, USA, $38 \mathrm{p}$.

Cederholm, C.J., and Peterson, N.P., 1985, The retention of coho salmon (Oncorhynchus kisutch) carcasses by organic debris in small streams: Canadian Journal of Fisheries and Aquatic Science, v. 42, p. 1,222-1,225.

Cederholm, C.J., and Scarlett, W.J., 1991, The beaded channel--a low cost technique for enhancing winter habitat of Coho salmon, in Colt, J., and White, R.J., eds., Fisheries Bioengineering Symposium 10, American Fisheries Society Symposium, (USA) Fisheries Bioengineering Symposium: American Fisheries Society, Bethesda, Maryland, USA, Bioengineering Section, p. 104-108.

Collins, B.D., and Dunne, T., 1989, Gravel transport, gravel harvesting, and channel bed degradation in rivers draining the southern Olympic Mountains, Washington, USA: Environmental Geology and Water Science, v. 13, p. 213-224.

Cooper, R., and Johnson, T.H., 1992, Trends in steelhead (Oncorhynchus mykiss)--abundance in Washington and along the Pacific Coast of North America: Washington Department of Wildlife, Fisheries Management Division Report no. 92-20, 102 p.

Cowan, L., 1991, Physical characteristics and intragravel survival of chum salmon in developed and natural groundwater channels in Washington, in Colt, J., and White, R.J., eds., Fisheries Bioengineering Symposium 10, American Fisheries Society Symposium, (USA) : American Fisheries Society, Bethesda, Maryland, USA, Bioengineering Section. p. 125-131.
Crumley, S.C., and Stober, Q.J., 1984, Skagit River interim agreement studies, volume I.--instream flow fish habitat analysis: Fisheries Research Institute, University of Washington, $126 \mathrm{p}$.

Elliot, S.T., 1986, Reduction of a Dolly Varden population and macrobenthos after removal of logging debris: Transactions of the American Fisheries Society, v. 115 , p. $392-400$.

Fausch, K.D., 1984, Profitable stream positions for salmonids--relating specific growth rate to net energy gain: Canadian Journal of Zoology, v. 62, p. 441-451.

Fausch, F.D., Hawkes, C.L., and Parsons, M.G., 1988, Models that predict standing crop of stream fish from habitat variables, 1950-85: Portland, Oregon, U.S. Department of Agriculture, Forest Service, Pacific Northwest Research Station, General Technical Report PNW-GTR-213, 52 p.

Foster, R.W., Bagatell, C., and Fuss, H.J., 1981, Return of one year old pink salmon to a stream in Puget Sound: Progressive Fish Culture, v. 43, p. 31.

Fraidenburg, M.E., and Lincoln, R.H., 1985, Wild chinook salmon management-an international conservation challenge: North American Journal of Fisheries Management, v. 5, p. 311-329.

Gall, G., 1991, Snake River chinook salmon-harvest as a cause of decline: National Marine Fisheries Service, Endangered Species Act Administrative Record.

Gould, S.J., 1989, Wonderful life - the Burgess Shale and the nature of history: New York, W.W. Norton, $347 \mathrm{p}$.

Gislason, J.C., 1985, Aquatic insect abundance in a regulated stream under fluctuating and stable diel flow patterns: North American Journal of Fisheries Management, v. 5, p. 39-46.

Grosse, D.J., 1989, Effectiveness of forestry best management practices in protecting fish resources of two national forests in western Washington: Ecological Research Service, U.S. Environmental Protection Agency EPA-600-9-89-076, 49 p. 
Gurtz, M.E., 1994, Design of biological components of the National Water-Quality Assessment (NAWQA) Program, Chap. 15, in Loeb, S.L., and Spacie, A., eds., Biological monitoring of aquatic systems: Boca Raton, Fla., Lewis Publishers, p. 323-354.

Gustav, R.S., Sovern, D.T., and Washington, P.M., 1994, Maintaining fish habitat in urban streams: Water and Environmental Technology, v. 6, p. 48-53.

Hankin, D.G., and Reeves, G.H., 1988, Estimating total fish abundance and total habitat area in small streams based on visual estimation methods: Canadian Journal of Fisheries and Aquatic Science, v. 45, p. 834-844.

Harr, R.D., and Nichols, R.A., 1993, Stabilizing forest roads to help restore fish habitats--a northwest Washington example: Fisheries, v. 18, p. 18-23.

Hynes, H.B.N., 1970, The ecology of running waters: Bungay, Suffolk, England, Richard Clay Ltd., 555 p.

Hisata, J.S., Anadromous fish program evaluation--an evaluation of stocking semi-natural pond reared sea run cutthroat trout, (Salmo clarki clarki) in some tributary streams of Hood Canal, Washington State: Washington Department of Game, $40 \mathrm{p}$.

Horner, R.R., and Welch, E.B., 1981, Stream periphyton development in relation to current velocity and nutrients: Canadian Journal Of Fisheries and Aquatic Science, v. 38, p. 449-457.

Houston, Douglas B., and Contor, Roger J., 1984, An anadromous fish in Olympic National Park--status and management considerations, in Walton, J.M., and Houston, D.B., eds., Proceedings of the Olympic Wild Fish Conference, 1984, p. 97-111.

Hulett, P.L., and Leider, S.A., 1993, Genetic conservation of wild steelhead in Washington streams--a genetically based conservation and management model to integrate hatchery and wild production: Washington Department of Wildlife Report no. 93-17, $72 \mathrm{p}$.

Karr, J.R., 1981, Assessment of biotic integrity using fish communities: Fisheries, v. 6, p. 21-27.
Karr, J.R., 1995, Clean water is not enough: Illahee, v.11, p. 51-59.

Knudsen, E.E., and Dilley, S.J., 1987, Effects of riprap bank reinforcement on juvenile salmonids in four western Washington streams: North American Journal of Fisheries Management, v. 7, p. 351-356.

Konecki, J.T., Woody, C.A., and Quinn, T.P., 1995, Critical thermal maxima of coho salmon (Oncorhynchus kisutch) fry under field and laboratory acclimation regimes: Canadian Journal of Zoology, v. 73, p. 993-996.

Konkel, G., 1992, Salmon escapement information system: Northwest Science, v. 66, p. 140.

Kruckeberg, A., 1991, The natural history of Puget Sound, Washington: Seattle, Washington, University of Washington Press, $460 \mathrm{p}$.

Lanka, R.P., Hubert, W.A., and Wesche, T.A., 1987, Relations of geomorphology to stream habitat and trout standing stock in small Rocky Mountain streams: Transactions of the American Fisheries Society, v. 116, p. 21- 28.

Laufle, J.C., Pauley, G.B., and Shepard, M.F., 1986, Species profiles--life histories and environmental requirements of coastal fishes and invertebrates (Pacific Northwest) Coho salmon: U.S. Fish and Wildlife Service Biological Report 82(11.48), 28 p.

Lestelle, L.C., 1978, The effect of forest debris removal on a population of resident cutthroat trout in a small headwater stream: Seattle, Wash., University of Washington, M.S. thesis, $86 \mathrm{p}$.

Lonzarich, D., 1992, Patterns of community structure and microhabitat use by stream fishes in three Washington streams: Northwest Science, v. 66, p. 137.

Lonzarich, D.G., 1994, Stream fish communities in Washington--patterns and processes: Seattle, Washington, University of Washington, Ph.D. Thesis, $121 \mathrm{p}$. 
Lonzarich, D.G., and Quinn, T.P., 1995, Experimental evidence for the effect of depth and structure on the distribution, growth, and survival of stream fishes: Canadian Journal of Zoology, v. 73, p. 2,223-2,230.

Martin, D.J., Whitmus, C.J., Nevissi, A.E., Cox, J.M., and Brocklehurst, L.A., 1989, Effects of petroleum contaminated waterways on migratory behavior of adult pink salmon: Seattle, Washington, USA, Dames and Moore, $258 \mathrm{p}$.

Maret, T.R., 1995, Water-quality assessment of the upper Snake River Basin, Idaho and western Wyoming Summary of aquatic biological data for surface water through 1992: U.S. Geological Survey WaterResources Investigations Report 95-4006, 59 p.

Mathews, S.B., 1978, Trends in Puget Sound and Columbia River coho salmon, in McNeil, W.J., and Himsworth, D.C., eds., Proceedings of a Symposium on Salmonid Ecosystems of the North Pacific Ocean: Corvallis, Oregon, Oregon State University Sea Grant College Program, p. 133-145.

Mathews, S.B., and Olson, F.W., 1980, Factors affecting Puget Sound coho salmon (Oncorhynchus kisutch) runs: Canadian Journal of Fisheries and Aquatic Science, v. 37, p. 1,373-1,378.

Matthews, G.B., Matthews, R.A., and Hachmoller, B., 1991, Mathematical analysis of temporal and spatial trends in the benthic macroinvertebrate communities of a small stream: Canadian Journal of Fisheries and Aquatic Science, v. 48, p. 2,184-2,190.

McCain, B.B., Malins, D.C., Krahn, M.M., Brown, D.W., Gronlund, W.D., Moore, L.K., and Chan, S.L., 1990, Uptake of aromatic and chlorinated hydrocarbons by juvenile chinook salmon (Oncorhynchus tshawytscha) in an urban estuary: Archives of Environmental Contamination and Toxicology, v. 19, p. 10-16.

McIsaac, D.O., and Quinn, T.P., 1988, Evidence for a hereditary component in homing behavior of chinook salmon (Oncorhynchus tshawytscha): Canadian Journal of Fisheries and Aquatic Science, v. 45, p. 2,201-2,205.
McMichael, G.A., and Kaya, C.M., 1991, Relations among stream temperature, angling success for rainbow trout and brown trout, and fisherman satisfaction: North American Journal of Fisheries Management, v. 11, p. 190-199.

Mercer, S.P., and Johnston, J.M., 1979, Inland and marine gamefish research--sea run cutthroat-- development and evaluation of a new enhancement technique:

Washington State Department of Fisheries, F-068-R-03, $47 \mathrm{p}$

Meyer, Jon, 1992, Restoration of the Elwha River ecosystem: Western Division American Fisheries Society, July 13-16, 1992, Program Abstracts, p. 63.

Michael, J.H., Jr., 1995, Enhancement effects of spawning pink salmon on stream rearing juvenile coho salmon--managing one resource to benefit another: Northwest Science, v. 69, p. 228-233.

Moyle, P.B., and Herbold, B., 1987, Life history patterns and community structure in stream fishes of western North America - comparisons with eastern North America and Europe, in Mathews, W.J. and Heins, D.C., eds., Community and Evolutionary Ecology in North American Stream Fishes: Norman, Okla., University of Oklahoma Press, p. 25-32.

Muller, T.A., 1979, Sauk River native steelhead research--study life history cycle and gather baseline data: Washington Department of Game, F-070-R-01, $44 \mathrm{p}$.

Murdoch, T.B., 1983, Integration of salmon enhancement in water quality planning--a case study--salmonid reproduction, in Salmonid Reproduction--An International Symposium, 31 October-2 November, 1983, Bellevue, Wash., (USA), University of Washington, Seattle, Washington, USA, Sea Grant Program, 1983, p. 14.

Nickelson, T.E., Solazzi, M.F., and Johnson, S.L., 1986, Use of hatchery coho salmon (Oncorhynchus kisutch) presmolts to rebuild wild populations in Oregon coastal streams: Canadian Journal of Fisheries and Aquatic Sciences, v. 43, p. 2,443-2,449. 
Orsborn, J.F., and Anderson, J.W., 1986, Stream improvements and fish response--a bio-engineering assessment: Water Resources Bulletin, v. 22, p. 381-388.

Parton, Michael J., 1990, Status and trends of streams in forested lands in Washington--the Timber, Fish and Wildlife Ambient Monitoring Project, in Proceedings, Annual Conference of Western Association of Fish and Wildlife Agencies, no. 70., p. 170.

Pimm, S.L., 1982, Food webs: London, Chapman and Hall, 219 p.

Quinn, T.P., and Peterson, N.P., 1994, The effect of forest practices on fish populations: Timber, Fish and Wildlife, Washington Department of Natural Resources, TFW-F4-94-001, $157 \mathrm{p}$.

Quinn, T.P., Tallman, R.F., 1987, Seasonal environmental predictability and homing in riverine fishes:

Environmental Biology of Fish, v. 18, p. 155-159.

Quinn, T.P., Wood, C.C., Margolis, L., Riddell, B.E., and Hyatt, K.D., 1987, Homing in wild sockeye salmon (Oncorhynchus nerka) populations as inferred from differences in parasite prevalence and allozyme allele frequencies: Canadian Journal of Fisheries and Aquatic Science, v. 44, p. 1,963-1,971.

Ralph, S.C., Poole, G.C., Conquest, L.L., and Naiman, R.J., 1994, Stream channel morphology and woody debris in logged and unlogged basins of western Washington: Canadian Journal of Fisheries and Aquatic Science, v. 51, p. 37-51.

Reisenbichler, R.R., and McIntyre, J.D., 1977, Genetic differences in growth and survival of juvenile hatchery and wild steelhead trout, Salmo gairdneri: Journal of the Fisheries Research Board of Canada, v. 34 , no. 1 , p. $123-128$.

Reiser, D.W., and Bjornn, T.C., 1979, Habitat requirements of anadromous salmonids, in Meehan, W.R., ed., Influence of forest and Rangeland Management on Anadromous Fish Habitat in the Western United States and Canada: Portland, Oreg., U.S. Forest Service General Technical Report PNW-96, unpaginated.
Riddel, B.E., and Swain, D.P., 1991, Competition between hatchery and wild coho salmon (Oncorhynchus kisutch)—genetic variation for agonistic behavior in newly-emerged wild fry: Aquaculture, v. 98, p. 161-172.

Royal, L.A., 1972, An examination of the anadromous trout program of the Washington State Game Department: Olympia, Wash., Washington Department of Game, $196 \mathrm{p}$.

Sabo, J.L., 1995, Competition between stream-dwelling cutthroat trout (Oncorhynchus clarki clarki) and coho salmon (O. kisutch)--implications for community structure and evolutionary ecology: Seattle, Washington, University of Washington, M.S. Thesis, $82 \mathrm{p}$.

Samuelson, C.E., 1984, Logging and fish habitat-preliminary review of the results of a long term study of five streams in the Olympic Peninsula, Washington, in Meehan, W.R., Merrell, T.R., Jr., and Hanley, T.A., eds., Fish and Wildlife Relationships in Old Growth Forests: American Institute of Fisheries Resource Biology, $151 \mathrm{p}$.

Saunders, R.L., and Sprague, J.B., 1967, Effect of copperzinc mining pollution on a spawning migration of Atlantic salmon: Water Resources, v.1, p. 419-432.

Scott, J.B., Steward, C.R., and Stober, Q.J., 1986, Effects of urban development of fish population dynamics in Kelsey Creek, Washington: Transactions of the American Fisheries Society, v. 115, p. 555-567.

Shelford, V.E., 1911, Ecological succession. I. Stream fishes and the method of physiographic analysis: Woods Hole, Mass., Biological Bulletin of the Marine Biological Laboratory, v. 21, p. 9-35.

Smith, C.J., and Wampler, P., 1995, Dungeness River chinook salmon rebuilding project progress report 1992-1993: Northwest Indian Fisheries Commission, $72 \mathrm{p}$.

Steinmann, P., 1907, Die Tierwelt der Gebirgsbache. Enin Faunistisch-biologische Studie: Annales de Biologie Lacustre, v. 2, p. 30-150. 
Steward, C.R., and Stober, Q.J., 1983, South Fork Snoqualmie River (Twin Falls) instream flow resident fish habitat analysis: University of Washington, School of Fisheries, Fisheries Research Institute, $72 \mathrm{p}$.

Stober, Q.J., and Hamalainen, A.H., 1980, Cedar River sockeye salmon production, 1980: Seattle, Wash., University of Washington, USA, Fisheries Research Institute, (FRI-UW-8016), $59 \mathrm{p}$.

Stober, Q.J., and Hamalainen, A.H., 1981, South Everett drainage basins study fisheries survey: Seattle, Wash., University of Washington, Fisheries Research Institute, $26 \mathrm{p}$.

Theinemann, A., 1912, Der Bergbach des Sauerland: Internationale Revue der gesmten Hydrobiologie Supplement 4, $125 \mathrm{p}$.

Tschaplinski, P.J., and Hartman, G.F., 1983, Winter distribution of juvenile coho salmon (Oncorhynchus kisutch) before and after logging in Carnation Creek, British Columbia, and some implications for overwinter survival: Canadian Journal of Fisheries and Aquatic Science, v. 40, p. 452-461.

Washington Department of Fisheries, 1974, Status of the salmon resources of Puget Sound Region, Washington: Olympia, Wash., Management and Research Division, 4 p.

Washington Department of Fisheries, 1975, Status of the salmon resources of Puget Sound and Coastal Region, Washington: Management and Research Division, $13 \mathrm{p}$.

Washington, P.M., 1984, Fishery enhancement survey of upper Skagit River tributaries: University of Washington, Fishery Research Institute, 207 p.

Whitaker, G.A., McCuen, R.H., and Brush, J., 1979, Channel modification and macroinvertebrate community diversity in small streams: Water Resources Bulletin, v. 15, p. 874-879.

Wilzbach, M.A., 1985, Relative roles of food abundance and cover in determining the habitat distribution of stream-dwelling cutthroat trout (Salmo clarki): Canadian Journal of Fisheries and Aquatic Science, v. 42 , p. $1,668-1,672$.
Wissmar, R.C., and Beer, W.N., 1994, Distribution of fish and stream habitats and influences of watershed conditions, Beckler River, Washington: University of Washington, Fisheries Research Institute, School of Fisheries, $52 \mathrm{p}$.

Woodin, R.M., Crumley, S.C., Stober, Q.J., and Engman, G., 1984, Skagit River interim agreement studies, volume II, salmon and steelhead studies: University of Washington, Fisheries Research Institute, 61 p.

Wunderlich, R.C., Meyer, J.H., and Boomer, R.S., 1982, Nooksack River juvenile spring chinook salmon investigations: U.S. Department of the Interior, Fisheries Assistance Office, U.S. Fish and Wildlife Service, $61 \mathrm{p}$.

Wunderlich, R.C., Winter, B.D., and Meyer, J.H., 1994, Restoration of the Elwha River ecosystem:

Fisheries, v. 19, p. 11-20.

\section{Instream and Riparian Habitat}

\section{Primary Information Sources}

Bilby, Robert E., and Ward, James W., 1991, Characteristics and function of large woody debris in streams draining old-growth, clear cut, and second growth forests in southwestern Washington: Canadian Journal of Fisheries and Aquatic Science, v. 48, p. 2,499-2,508.

Bisson, P.A., Quinn, T.P., Reeves, G.H., and Gregory, S.V., 1992, Best management practices, cumulative effects, and long-term trends in fish abundance in Pacific Northwest river systems, in Naiman, R.J., ed., Watershed Management--Balancing Sustainability and Environmental Change: New York, SpringerVerlag, p. 189-232.

Buchman, I.L., 1936, Lumbering and logging in the Puget Sound Region in territorial days: Pacific Northwest Quarterly, v. 27, p. 34-53.

Fegeas, R.G., Claire, R.W., Guptill, S.L., Anderson, K.E., and Hallan, C.A., 1983, Land use and cover digital data: U.S. Geological Survey Circular 895-E. 
Harmon, M.E., Franklin, J.F., Swanson, F.J., Sollins, P., Gregory, S.V., Lattin, J.D., Anderson, N.H., Cline, S.P., Aumen, N.G., Sedell, J.R., Lienkaemper, G.W., Cormack, K., and Cummins, K.W., 1986, Ecology of coarse woody debris in temperate ecosystems, in Advances in Ecological Research: New York, Academic Press, p. 133-302.

King County Surface Water Management Division, 1987, Basin reconnaissance program summary volume 3: Seattle, Wash., King County Surface Water Management Division, unpaginated.

King County Surface Water Management Division, 1993, Cedar River current and future conditions summary report: Seattle, Wash., King County Surface Water Management Division, 82 p., appendices.

Kruckeberg, A., 1991, The natural history of Puget Sound, Washington: University of Washington Press, Seattle, Washington, $460 \mathrm{p}$.

Naiman, R.J., Beechie, T.J., Benda, L.E., Berg, D.R., Bisson, P.A., MacDonald, L.H., O'Connor, M.D., Olson, P.L., and Steel, E.A., 1992, Fundamental elements of ecologically healthy watershed in the Pacific northwest coastal ecoregion, in Naiman, R.J., ed., Watershed Management--Balancing Sustainability and Environmental Change: New York, Springer-Verlag, $542 \mathrm{p}$.

Omernik, J.M., 1987, Ecoregions of the conterminous United States (with map): Annals of the Association of American Geographers, no. 77, p. 118-125.

Omernik, J.M., and Gallant, A.L., 1986, Ecoregions of the Pacific Northwest (with map): Corvallis, Oreg., U.S. Environmental Protection Agency report EPA/600/ 3-86/033, $39 \mathrm{p}$.

Puget Sound Water Quality Authority, 1988, State of the Sound 1988 report: Seattle, Washington, Puget Sound Water Quality Authority, 225 p.

Ralph, S.C., Cardoso, T., Poole, G.C., Conquest, L.L., and Naiman, R.J., 1991, Status and trends of instream habitat in forested lands of Washington--the Timber, Fish and Wildlife ambient monitoring project, 1989-1991 Biennial Progress Report: Center for Stream Side Studies, University of Washington, Seattle, Washington, TFW-AM9-91-002, 58 p.
Ralph, S.C., Poole, G.C., Conquest, L.L., and Naiman, R.J., 1994, Stream channel morphology and woody debris in logged and unlogged basins of western Washington: Canadian Journal of Fisheries and Aquatic Science, v. 51, p. 37-51.

Schuett-Hames, D., Pleus, A., and McDonald, D., 1994, TFW ambient monitoring program--1993-94 status report: TFW-AM9-94-002, $11 \mathrm{p}$.

SSHIAP, 1995, Salmon and steelhead habitat inventory and assessment project--wild salmon stock restoration initiative: Northwest Indian Fisheries Commission, 8 p.

U.S. Army Corps of Engineers, 1994, Water Control Infrastructur--National Inventory of Dams, Updated Data--1993-94: Washington, D.C., Federal Emergency Management Agency, National Dam Safety Program, CD-ROM.

U.S. Department of Agriculture, 1992, Census of agriculture--geographic area series--v. 1: Agriculture Division, Bureau of the Census, from URL gopher: //11eos. esuda.gov/11/server/gopher/ 99-census-browse WA.

Vaccaro, J.J., Hansen, A.J., Jr., and Jones, M.A., in press, Hydrogeologic framework of the Puget Sound aquifer system, Washington and Canada--A contribution of the Regional Aquifer-System Analysis: U.S. Geological Survey Professional Paper 1424-D.

Washington Department of Ecology, 1995, Draft--state of the Nooksack River watershed: Bellingham, Wash., Washington Department of Ecology, Nooksack Initiative Office, $124 \mathrm{p}$.

Washington State Department of Fish and Wildlife, 1995, Fish passage database: Olympia, Wash., Washington State Department of Fish and Wildlife, MS Excel computer spreadsheet format.

Washington Department of Fish and Wildlife and Western Washington Treaty Indian Tribes, 1993, 1992 Washington State salmon and steelhead stock inventory--summary: Olympia, Washington, 212 p. 
Washington State Department of Fish and Wildlife and Western Washington Treaty Indian Tribes, 1994, 1992 Washington State salmon and steelhead stock inventory, appendix one and appendix two: Olympia, Washington, 789 p.

Williams, J.R., 1981, Principal surface-water inflow to Puget Sound, Washington: U.S. Geological Survey Water-Resources Investigations Report 84-4090, 6 p.

\section{Secondary Information Sources}

Abbe, T.B., Montgomery, D.R., 1996, Large woody debris jams, channel hydraulics and habitat formation in large rivers--regulated rivers research and management (Chichester), in Saltveit, S.J., ed., Proceedings of the First International Symposium on Habitat Hydraulics, Trondheim, Norway, 18-20 August, 1994, v. 12, no. 2-3, p. 201-221.

Angermeier, P.L., and Karr, J.R., 1984, Relationships between woody debris and fish habitat in a small warmwater stream: Transactions of the American Fisheries Society, v. 113, p. 716-726.

Beecher, Hal A., Dott, Eric R., and Fernau, Robert F., 1988, Fish species richness and stream order in Washington State streams: Environmental Biology of Fishes, v. 22, p. 193-209.

Beechie, T.J., and Sibley, T.H., 1989, Evaluation of the Timber, Fish and Wildlife stream classification system-- stratification of physical habitat area and distribution--annual report, 1988-1989: Timber, Fish and Wildlife Project, Washington Department of Natural Resources, TFW-16B-89-006, 62 p.

Beechie, T., Beamer, E., and Wasserman, L., 1994, Estimating coho salmon rearing habitat and smolt production losses in a large river basin, and implications for habitat restoration: North American Journal of Fisheries Management, v. 14, p. 797-811.

Benda, L., Beechie, T.J., Wissmar, R.C., and Johnson, A., 1992, Morphology and evolution of salmonid habitats in a recently deglaciated riverbasin, Washington State, USA: Canadian Journal of Fisheries and Aquatic Science, v. 49, p. 1,246-1,256.
Benke, A.C., and Wallace., J.B., 1990, Wood dynamics in Coastal Plain blackwater streams: Canadian Journal of Fisheries and Aquatic Science, v. 47, p. 92-99.

Bilby, R.E., Fransen, B.R., Bisson, P.A., 1996, Incorporation of nitrogen and carbon from spawning coho salmon into the trophic system of small streams-evidence from stable isotopes: Canadian Journal of Fisheries and Aquatic Science, v. 53, p. 164-173.

Bilby, Robert E., and Bisson, Peter A., 1987, Emigration and production of hatchery coho salmon (Oncorhynchus kisutch) stocked in streams draining an old growth and a clear cut watershed: Canadian Journal of Fisheries and Aquatic Science, v. 44, p. 1,397-1,407.

Bilby, Robert E., and Bisson, Peter A., 1992, Allochthonous versus autochthonous organic matter contributions to the trophic support of fish populations in clear cut and old growth forested streams: Canadian Journal of Fisheries and Aquatic Science, v. 49, p. 540-551.

Bilby, R.E., and Ward, J.W., 1989, Changes in characteristic and function of woody debris with increasing size of streams in western Washington. Transactions of the American Fisheries Society v. 118 , p. $368-378$.

Bilby, R.E., and Ward, J.W., 1991, Characteristics and function of large wood debris in streams draining old growth clear cut, and second growth forests in southwestern Washington: Canadian Journal of Fisheries and Aquatic Science, v. 48, p. 2,499-2,508.

Bisson, P.A., and Sedell, J.R., 1984, Salmonid populations in streams in clearcut vs. old-growth forests of western Washington, in Meehan, W.R., Merrell, T.R., Jr., and Hanley, T.A., eds., Fish and Wildlife Relationships in Old Growth Forest: American Institute of Fisheries Resource Biology, p. 121-130.

Bisson, Peter A., Sullivan, Kathleen, and Nielsen, Jennifer L., 1988, Channel hydraulics, habitat use, and body form of juvenile coho salmon, steelhead, and cutthroat trout in streams: Transactions of the American Fisheries Society, v. 117, p. 262-273. 
Bradley, J.B., and Whiting, P.J., 1992, A process-based stream classification system for small streams in Washington: Timber, Fish and Wildlife, Washington Department of Natural Resources, TFW-SH11-91-001, 70 p.

Brown, N.C., 1936. Logging-transportation--the principles and methods of log transportation in the U.S. and Canada: New York, John Wiley and Sons, 327 p.

Bryant, M.D., 1983, The role and management of woody debris in west coast salmonid nursery streams: North American Journal of Fisheries Management, v. 3, p. 322-330.

Caldwell, B.A., and Hirschey, S., 1989, Green River fish habitat analysis using the instream flow incremental methodology: Water Resources Program, Washington Department of Ecology, 148 p.

Campbell, R.F., and Neuner, J.H., 1985, Seasonal and diurnal shifts in habitat utilized by resident rainbow trout in western Washington Cascade Mountain streams, in Olson, Forrest W., White, Robert G., and Hamre, R.H., eds., Proceedings of the Symposium on Small Hydropower and Fisheries: p. 39-48.

Carlson, J.Y., Andrus, C.W., and Froehlich, H.A., 1990, Woody debris, channel features, and macroinvertebrates of streams with logged and undisturbed riparian timber in northeastern Oregon, U.S.A. Canadian Journal of Fisheries and Aquatic Science, v. 47 , p. $1,103-1,111$.

Cederholm, C.J., and Koski, K.V., 1977, Effects of stream channelization on the salmonid habitat and populations of lower Big Beef Creek, Kitsap County, Washington 1969-73: Washington Cooperative Fishery Research Unit, University of Washington, Seattle, Washington, $38 \mathrm{p}$.

Cederholm, C.J., and Peterson, N.P., 1985, The retention of coho salmon (Oncorhynchus kisutch) carcasses by organic debris in small streams: Canadian Journal of Fisheries and Aquatic Science, v. 42, p. 1,222-1,225.

Cederholm, C.J., and Scarlett, W.J., 1991, The beaded channel--a low cost technique for enhancing winter habitat of Coho salmon, in Colt, J., and White, R.J., eds., Fisheries Bioengineering Symposium:

American Fisheries Society, Bethesda, Maryland, USA, no. 10, p. 104-108.
Chapman, D.W., and Knudsen, E., 1980, Channelization and livestock impacts on salmonid habitat and biomass in western Washington: Transactions of the American Fisheries Society, v. 109, p. 357-363.

Cherry, J., and Beschta, R.L., 1989, Coarse woody debris and channel morphology--a flume study: Water Resources Bulletin, v. 25, p. 1,031-1,036.

Collins, B.D., and Dunne, T., 1989, Gravel transport, gravel harvesting, and channel bed degradation in rivers draining the southern Olympic Mountains, Washington: Environmental Geology and Water Science, v. 13, p. 213-224.

Cowan, L., 1991, Physical characteristics and intragravel survival of chum salmon in developed and natural groundwater channels in Washington, in Colt, J., and White, R.J., eds., Fisheries Bioengineering Symposium 10: American Fisheries Society, Bethesda, Maryland, USA, no. 10, p. 125-131.

Cox, T.R., Mills and markets--a history of the Pacific Coast lumber industry to 1900: Seattle, Wash., University of Washington Press, 396 p.

Crowder, L.B., and Cooper, W.E., 1982, Habitat structural complexity and the interaction between bluegills and their prey: Ecology, v. 63, p. 1,802-1,813.

Dolloff, C.A., 1986, Effects of stream cleaning on juvenile coho salmon and Dolly Varden in southeast Alaska: Transactions of the American Fisheries Society, v. 115 , p. $743-755$.

Doyle, James E., 1985, Habitat enhancement on off channels and terraced tributaries in Puget Sound river systems: American Fisheries Society Annual Meeting no. 115 , p. 51-52.

Dunne, T., and Leopold, L.B., 1978, Water in environmental planning: New York, W.H. Freeman and Company, $818 \mathrm{p}$.

Elliot, S.T., 1986, Reduction of a Dolly Varden population and macrobenthos after removal of logging debris: Transactions of the American Fisheries Society, v. 115 , p. $392-400$. 
Embrey, S.S., 1991, Available habitat for salmon and steelhead trout in the lower Puyallup, White, and Carbon Rivers in western Washington: U.S. Geological Survey Water- Resources Investigations Report 89-4125, 72 p.

Fausch, K.D., 1984, Profitable stream positions for salmonids--relating specific growth rate to net energy gain: Canadian Journal of Zoology: v. 62, p. 441-451.

Fausch, F.D., Hawkes, C.L., and Parsons, M.G., 1988, Models that predict standing crop of stream fish from habitat variables, 1950-85: Portland, Oregon, U.S. Department of Agriculture, Forest Service, Pacific Northwest Research Station, General Technical Report PNW-GTR-213, 52 p.

Fegeas, R.G., Claire, R.W., Guptill, S.L., Anderson, K.E., and Hallan, C.A., 1983, Land use and land cover digital data: U.S. Geological Survey Circular 895-E.

Gislason, J.C., 1980, Effects of flow fluctuation due to hydroelectric peaking on benthic insects and periphyton of the Skagit River: Seattle, Washington, University of Washington, Ph.D. Thesis, $175 \mathrm{p}$.

Gislason, J.C., 1985, Aquatic insect abundance in a regulated stream under fluctuating and stable diel flow patterns: North American Journal of Fisheries Management, v. 5, p. 39-46.

Greenberg, E.S., 1995, The influence of large woody debris on benthic invertebrate communities in two King County, Washington, streams: Seattle, Washington, University of Washington, M.S. Thesis, $107 \mathrm{p}$.

Gregory, S.V., Swanson, F.J., McKee, W.A., and Cummins, K.W., 1991, An ecosystem perspective of riparian zones: BioScience, v. 41, p. 540-551.

Gurtz, M.E., 1994, Design of biological components of the National Water-Quality Assessment (NAWQA) Program, chap. 15, in Loeb, S.L. and Spacie, A., eds., Biological monitoring of aquatic systems: Boca Raton, Fla., Lewis Publishers, p. 323-354.

Gustav, Richard S., Sovern, Douglas T., and Washington, Percy M., 1994, Maintaining fish habitat in urban streams: Water Environmental Technology, v. 6, p. $48-53$.
Hachmoeller, B., Matthews, R.A., and Brakke, D.F., 1991, Effects of riparian community structure, sediment size, and water quality on the macroinvertebrate communities in a small, suburban stream: Northwest Science, v. 65, p. 125-132.

Halbert, C.L., and Wissmar, R.C., 1994, Historical influences of forest practices on salmonid habitats in headwaters of the Skagit River Basin, Washington, in Link, G. Lee, and Naiman, Robert J., compilers, Proceedings of the International Workshop on the Ecology and Management of Aquatic Terrestrial Ecotones, February 14-19, 1994, University of Washington, Seattle, Washington, p. 146.

Hankin, D.G., and Reeves, G.H., 1988, Estimating total fish abundance and total habitat area in small streams based on visual estimation methods: Canadian Journal of Fisheries and Aquatic Science, v. 45, p. $834-844$.

Harmon, M.E., Franklin, J.F., Swanson, F.J., Sollins, P., Gregory, S.V., Lattin, J.D., Anderson, N.H., Cline, S.P., Aumen, N.G., Sedell, J.R., Lienkaemper, G.W., Cormack, K., and Cummins, K.W., 1986, Ecology of coarse woody debris in temperate ecosystems, in Advances in ecological research: New York, Academic Press, p. 133-302.

Harr, R.D., and Nichols, R.A., 1993, Stabilizing forest roads to help restore fish habitats--a northwest Washington example: Fisheries, v. 18, p. 18-23.

Helle, J.H., and Hoffman, M.S., 1995, Size decline and older age at maturity of two chum salmon (Oncorhynchus keta) stocks in western North America, 1972-92, in Beamish, R.J., ed., Climate Change and Northern Fish Populations Conference, Victoria, BC (Canada), 19-24 October, 1992, National Research Council of Canada, Ottawa, Ontario, Canada, no. 121, p. 245-260.

Hynes, H.B.N., 1970, The ecology of running waters: Bungay, Suffolk, England, Richard Clay Ltd., 555 p.

King County Surface Water Management Division, 1987, Basin reconnaissance program summary volume 3: King County, Surface Water Management Division, Seattle, Washington, unpaginated. 
King County Surface Water Management Division, 1993, Cedar River current and future conditions summary report: King County Department of Public Works, Surface Water Management Division, Seattle, Washington, 82 p., appendices.

Knudsen, E.E., and Dilley, S.J., 1987, Effects of riprap bank reinforcement on juvenile salmonids in four western Washington streams: North American Journal of Fisheries Management, v. 7, p. 351-356.

Kruckeberg, A., 1991, The natural history of Puget Sound, Washington: Seattle, Washington, University of Washington Press, 460 p.

Lanka, R.P., Hubert, W.A., and Wesche, T.A., 1987, Relations of geomorphology to stream habitat and trout standing stock in small Rocky Mountain streams: Transactions of the American Fisheries Society, v. 116, p. 21- 28.

Leopold, L.B., Wolman, M.G., and Miller, J.P., 1964, Fluvial processes in geomorphology: San Francisco, California, W. H. Freeman, 650 p.

Lestelle, L.C., 1978, The effect of forest debris removal on a population of resident cutthroat trout in a small headwater stream: Seattle, Wash., University of Washington, M.S. thesis, 86 p.

Lestelle, L.C., and Cederholm, C.J., 1984, Short term effects of organic debris removal on resident cutthroat trout, in Meehan, W.R., Merrell, T.R., Jr., and Hanley, T.A., eds., Fish and Wildlife Relationships in Old Growth Forests: American Institute of Fisheries Resource Biology, p. 131-140.

Likens, G.E., Bormann, F.H., Johnson, N.M., Fisher, D.W., and Pierce, R.S., 1970, Effects of forest cutting and herbicide treatment on nutrient budgets in Hubbard Brook Watershed--Ecosystem: Ecological Monographs, v. 40, p. 23-47.

Maret, T.R., 1995, Water-quality assessment of the upper Snake River Basin, Idaho and western Wyoming-summary of aquatic biological data for surface water through 1992: U.S. Geological Survey WaterResources Investigations Report 95-4006, 59 p.
McNab, W.H., and Avers, P.E., 1994, Ecological subregions of the United States, section descriptions--Administrative Publication WO-WSA-5: Washington D.C., U.S. Department of Agriculture, Forest Service, 267 p.

Michael, J.H., Jr., 1995, Enhancement effects of spawning pink salmon on stream rearing juvenile coho salmon--managing one resource to benefit another: Northwest Science, v. 69, p. 228-233.

Montgomery, D.R., 1993, Channel classification, prediction of channel response, and assessment of channel condition: Timber, Fish and Wildlife, Washington Department of Natural Resources, TFW-SH10-93-002, 84 p.

Montgomery, D.R., Buffington, J.M., Smith, R.D., Schmidt, K.M., and Pess, G., 1995, Pool spacing in forest channels: Water Resources Research no 31, p. 1,097-1,105.

Montgomery, D.R., Dunne, T., and Dietrich, W.E., 1993, Geomorphological watershed analysis project biennial report for the period from 10/1/91 to 6/30/93: Timber, Fish and Wildlife, Washington Department of Natural Resources, TFW-SH10-93-001.

Morgan, A., and Hinojosa, F., 1996, Literature review and monitoring recommendations for salmonid winter habitat: Timber, Fish and Wildlife, Washington Department of Natural Resources,

TFW-AM-9-96-004.

Nehlsen, Willa, Williams, Jack E., and Lichatowich, James A., 1992, Pacific salmon at the crossroads-stocks at risk from California, Oregon, Idaho, and Washington: Trout, v. 33, p. 24-51.

Newbold, J.D., Elwood, J.W., O'Neill, R.V., and Van Winkle, W., 1981, Measuring nutrient spiralling in streams: Canadian Journal of Fisheries and Aquatic Sciences, v. 38 , p. $860-863$.

Parton, Michael J., 1990, Status and trends of streams in forested lands in Washington--the Timber, Fish and Wildlife Ambient Monitoring Project, in Proceedings, Annual Conference of Western Association of Fish and Wildlife Agencies, no. 70, p. 170. 
Phelps, S.R., LeClair, L.L., Young, S., and Blankenship, H.L., 1994, Genetic diversity patterns of chum salmon in the Pacific Northwest: Canadian Journal of Fisheries and Aquatic Science, v. 51, p. 65-83.

Pickett, S.T.A., and White, P.S., eds., 1985, The ecology of natural disturbance and patch dynamics: Orlando, Fla., Academic Press, 283 p.

Poff, N.L., 1992, Why disturbance can be predictable--a perspective on the definition of disturbance in streams: Journal of the North American Benthological Society, v. 11, p. 86-92.

Quinn, T.P., and Peterson, N.P., 1994, The effect of forest practices on fish populations: Timber, Fish and Wildlife, Washington Department of Natural Resources, TFW-F4-94-001.

Reeves, Gordon H., Everest, Fred H., and Nickelson, Thomas E., 1989, Identification of physical habitats limiting the production of coho salmon in western Oregon and Washington: U.S. Forest Service General Technical Report (Region), PNW-GTR-245, $18 \mathrm{p}$.

Resh, V.H., Brown, A.V., Covich, A.P., Gurtz, M.E., Li, H.W., Minshall, G.W., Reice, S.R., and Sheldon, A.L., 1988, The role of disturbance in stream ecology: Journal of the North American Benthological Society, v. 7, p. 433-455.

Robison, E.G., and Beschta, R.L., 1990, Coarse woody debris and channel morphology interactions for undisturbed streams in southeast Alaska, USA: Earth Surface Processes and Landforms, v. 15, p. 149-156.

Sammeth, C.J., and Kraft, G.F., 1994, In search of Washington stoneflies: Northwest Science, v. 68, p. 148.

Samuelson, C.E., 1984, Logging and fish habitat-preliminary review of the results of a long term study of five streams in the Olympic Peninsula, Washington, in Meehan, W.R., Merrell, T.R., Jr., and Hanley, T.A., eds., Fish and Wildlife Relationships in Old Growth Forests: American Institute of Fisheries Resource Biology, p. 151.
Sedell, J.R., Everest, R.H., and Swanson, F.J., 1982, Fish habitat and stream side management--past and present--increasing forest productivity: Society of American Foresters, publication 82-01, p. 244-255.

Sedell, J.R., and Duval, W.S., 1985, Water transportation and storage of logs, in Meehan, W.R., ed., Influence of Forest and Rangeland Management on Anadromous Fish Habitat in Western North America: Portland, Oreg., U.S. Department of Agriculture, Forest Service, Pacific Northwest Forest and Range Experiment Station, General Technical Report PNW-186, p. 1-68.

Somers, D., Smith, J., and Wissmar, R., 1991, Watershed and stream channel cumulative effects analysis using aerial photography and ground survey data--interim report: Timber, Fish and Wildlife, Washington Department of Natural Resources, TFW-SH8-91-001, $81 \mathrm{p}$.

Stanford, J.A., and Ward, J.V., 1988, The hyporehic habitat of river ecosystems: Nature, v. 335, p. 64-66.

Swanson, F.J., and Lienkaemper, G.W., 1978, Physical consequences of large organic debris in Pacific northwest streams: U.S. Department of Agriculture, Forest Service, General Technical Report PNW-69, 12 p.

Vannote, R.L., Minshall, G.W., Cummins, K.W., Sedell J.R., and Crushing, C.E., 1980, The river continuum concept: Canadian Journal of Fisheries and Aquatic Science, v. 37, p. 130-137.

Washington, P.M., 1984, Fishery enhancement survey of upper Skagit River tributaries: University of Washington, Fishery Research Institute, 207 p.

Wilzbach, M.A., 1985, Relative roles of food abundance and cover in determining the habitat distribution of stream-dwelling cutthroat trout (Salmo clarki): Canadian Journal of Fisheries and Aquatic Science, v. 42, p. $1,668-1,672$. 
Wissmar, R.C., and Beer, W.N., 1994, Distribution of fish and stream habitats and influences of watershed conditions, Beckler River, Washington: Fisheries Research Institute, School of Fisheries, University of Washington, $52 \mathrm{p}$.

Wissmar, Robert, Halbert, Cindy, Chu, Jim, and Doyle, Jim, 1993, Skagit Wild and Scenic River-management status and issues, in Riparian Management--Common Threads and Shared Interests, A Western Regional Conference on River Management Strategies: February 4-6, 1993, Albuquerque, New Mexico, U.S. Forest Service General Technical Report RM-226, p. 373-387.

\section{Aquatic Invertebrates}

\section{Primary Information Sources}

Brenner, R., and Morrice, R., 1978, Routine streams survey interim report: Municipality of Metropolitan Seattle, Seattle, Washington, $49 \mathrm{p}$.

Kleindl, W., 1995, A benthic index of biotic integrity for Puget Sound Lowland streams, Washington, USA: Seattle, Washington, University of Washington, UA, M.S. Thesis, $59 \mathrm{p}$.

Matthews, G.B., Matthews, R.A., and Hachmoller, B., 1991, Mathematical analysis of temporal and spatial trends in the benthic macroinvertebrate communities of a small stream: Canadian Journal of Fisheries and Aquatic Science, v. 48, p. 2,184-2,190.

Municipality of Metropolitan Seattle, 1977, A baseline study of the benthic community in small streams: Seattle, Wash., Municipality of Metropolitan Seattle, Water Quality Planning, 83 p.

Plotnikoff, R.W., 1992, Timber, Fish, and Wildlife ecoregion bioassessment pilot project: Olympia, Wash., Washington State Department of Ecology, publication no. 92-63, TFW-WQ11-92-001, $57 \mathrm{p}$.

Plotnikoff, R.W., 1994, Instream biological assessment monitoring protocols--benthic macroinvertebrates: Olympia, Wash., Washington State Department of Ecology, publication no. 94-113, TFW-WQ1192-001, $27 \mathrm{p}$.

\section{$\underline{\text { Secondary Information Sources }}$}

Benke, A.C., VanArsdall, T.C., Gillespie, D.M., and Parrish, F.K., 1984, Invertebrate productivity in a subtropical blackwater river--the importance of habitat and life history: Ecology Monographs, v. 54, p. 25-63.

Carlson, J.Y., Andrus, C.W., and Froehlich, H.A., 1990, Woody debris, channel features, and macroinvertebrates of streams with logged and undisturbed riparian timber in northeastern Oregon, USA, Canadian Journal of Fisheries and Aquatic Science, v. 47 , p. $1,103-1,111$.

Dudley, T., and Anderson, N.H., 1982, A survey of invertebrates associated with wood debris in aquatic habitats: Melanderia, v. 39, p. 1-21.

Elliot, S.T., 1986, Reduction of a Dolly Varden population and macrobenthos after removal of logging debris: Transactions of the American Fisheries Society, v. 115 , p. $392-400$.

Fore, L.S., Karr, J.R., and Wisseman, R.W., 1996, Assessing invertebrate responses to human activities--evaluating alternative approaches: Journal of the North American Benthological Society, v. 15, p. 212-231.

Gislason, J.C., 1980, Effects of flow fluctuation due to hydroelectric peaking on benthic insects and periphyton of the Skagit River, Washington: Seattle, Washington, USA, University of Washington, USA, Ph.D. Thesis, $175 \mathrm{p}$.

Gislason, J.C., 1985, Aquatic insect abundance in a regulated stream under fluctuating and stable diel flow patterns: North American Journal of Fisheries Management, v. 5, p. 39-46.

Goodpasture, L.M., 1986, The effects of anthropogenic disturbances on benthic faunal communities in Thornton and Coal Creek, King County, Washington: Seattle, Washington, University of Washington School of Forestry, M.S. Thesis, $110 \mathrm{p}$.

Greenberg, E.S., 1995, The influence of large woody debris on benthic invertebrate communities in two King County, Washington, streams: Seattle, Washington, University of Washington, M.S. Thesis, $107 \mathrm{p}$. 
Gurtz, M.E., 1994, Design of biological components of the National Water-Quality Assessment (NAWQA) Program, chap. 15, in Loeb, S.L. and Spacie, A., eds., Biological Monitoring of Aquatic Systems: Boca Raton, Fla., Lewis Publishers, p. 323-354.

Hachmoeller, B., Matthews, R.A., and Brakke, D.F., 1991, Effects of riparian community structure, sediment size, and water quality on the macroinvertebrate communities in a small, suburban stream: Northwest Science, v. 65, p. 125-132.

Hart, D.D., 1978, Diversity in stream insects--regulation by rock size and microspatial complexity: Verhandlungen Internationale Vereinigung fur theoretische und angewandte Limnologie, v. 20, p. 1,376-1,381.

Hynes, H.B.N., 1970, The ecology of running waters: Bungay, Suffolk, England, Richard Clay Ltd., 555 p.

Karr, J.R., 1995, Clean water is not enough: Illahee, v. 11, p. 51-59.

Malic, J.G., 1977, Ecology of benthic insects of the Cedar River, Washington: Seattle, Washington, University of Washington, Ph.D. Thesis, $181 \mathrm{p}$.

Maret, T.R., 1995, Water-quality assessment of the upper Snake River Basin, Idaho and western Wyoming-Summary of aquatic biological data for surface water through 1992: U.S. Geological Survey WaterResources Investigations Report 95-4006, 59 p.

Phillips, D.J.H., 1980, Quantitative aquatic biological indicators: London, Applied Science Publishers Ltd., $488 \mathrm{p}$.

Pimm, S.L., 1982, Food webs: London, Chapman and Hall, $219 \mathrm{p}$.

Rosenberg, D.M., and Resh, V.H., 1993, Introduction to freshwater biomonitoring and benthic macroinvertebrates, in Rosenberg and Resh, eds., Freshwater biomonitoring and benthic macroinvertebrates: New York, Chapman and Hall, $488 \mathrm{p}$.

Sammeth, C.J., and Kraft, G.F., 1994, In search of Washington stoneflies: Northwest Science, v. 68, p. 148.
Specht, M.L., 1978, Inland and marine gamefish research--appendix ii, study of the stomach contents of sexually mature and immature sea run cutthroat trout during fall migration to the Stillaguamish River in Washington State: Washington Department of Fisheries F-068-R-02, 16 p.

Stanford, J.A., and Ward, J.V., 1988, The hyporheic habitat of river ecosystems: Nature, v. 335, p. 64-66.

Stober, Q.J., and Hamalainen, A.H., 1981, South Everett drainage basins study fisheries survey: Fisheries Research Institute, University of Washington, $26 \mathrm{p}$.

Thorp, J.H., and Covich, A.P., 1991, Introduction to freshwater invertebrates, in Thorp, J.H., and Covich, A.P., eds., Ecology and Classification of North American Freshwater Invertebrates: New York, Academic Press, Inc., p. 911.

Ward, J.V., and Short, R.A., 1978, Macroinvertebrate community structure of four special lotic habitats in Colorado, USA: Verhandlungen Internationale Vereinigung fur theoretische und angewandte Limnologie, v. 20, p. 1,382-1,387.

Williams, D.D., 1980, Some relationships between stream benthos and substrate heterogeneity: Limnology and Ocenography, v. 25, p. 166-172.

\section{Temperature}

Adams, T.N., and Sullivan, K., 1989, The physics of forest stream heating--a simple model: Timber, Fish and Wildlife, Washington Department of Natural Resources, TFW-WQ3-90-007, $30 \mathrm{p}$.

Bilby, R.E., 1984, Characteristics and frequency of cool water areas in a western Washington stream: Journal of Freshwater Ecology, v. 2, p. 593-602.

Caldwell, J.E., Doughty, K., and Sullivan, K., 1991, Evaluation of downstream temperature effects on type 4/5 waters: Timber, Fish and Wildlife, Washington Department of Natural Resources, TFW-WQ5-91-004. 
Chatters, J.C., Neitzel, D.A., Scott, M.J., and Shankle, S.A., 1991, Potential impacts of global climate change on Pacific Northwest spring chinook salmon (Oncorhynchus tshawytscha)--an exploratory case study: Northwest Environmental Journal, v. 7 , p. 71-92.

Collings, M.R., 1973, Generalizations of streamtemperature data in Washington: U.S. Geological Survey Water-Supply Paper 2029-B.

Konecki, J.T., Woody, C.A., and Quinn, T.P., 1995, Critical thermal maxima of coho salmon (Oncorhynchus kisutch) fry under field and laboratory acclimation regimes: Canadian Journal of Zoology, v. 73, p. 993-996.

Konecki, J.T., Woody, C.A., and Quinn, T.P., 1995, Influence of temperature on incubation rates of coho salmon (Oncorhynchus kisutch) from ten Washington populations: Northwest Science, v. 69, p. 126-132.

Paulev, G., Bortz, B., Shepard, M., 1986, Species profiles--life histories and environmental requirements of coastal fishes and invertebrates (Pacific Northwest) steelhead trout: Biological Report, U.S. Fish and Wildlife Service, University of Washington, Seattle, Washington, USA, College of Ocean Fishery Sciences, 34 p.

Paulson, A.J., Curl, H.C., Feely, R.A., Massoth, G.J., and Krogslund, K.A., 1991, Trace metal and ancillary data in the watersheds and urban embayments of Puget Sound: National Oceanic and Atmospheric Administration, NOAA-DR-ERL-PMEL-30, Contribution 1097, Seattle, Washington, USA.

Sullivan, K., Tooley, J., Doughty, K., Calwell, J.E., and Knudsen, P., 1990, Evaluation of prediction models and characterization of stream temperature regimes in Washington: Timber, Fish and Wildlife Report no. TFW-WQ3-90-006, Washington Department of Natural Resources, Olympia, Washington, 224 p.

Vervier, P., and Naiman, R.J., 1992, Spatial and temporal fluctuations of dissolved organic carbon in subsurface flow of the Stillaguamish River (Washington, USA): Archive of Hydrobiologia, v. 123, p. $401-412$.

\section{Tissue Contamination}

Canfield, T.J., Kemble, N.E., and Ingersol, C.G., 1995, Use of chironomid deformities in field and laboratory assessments of contaminated sediments: 16th Annual Meeting of Society of Environmental Toxicology and Chemistry, Vancouver, British Columbia Canada.

Colborn, T., vom Saal, F.S., and Soto, A.M., 1993, Developmental effects of endocrine-disrupting chemicals in wildlife and humans: Environmental Health Perspectives, v. 101, p. 378-384.

Crawford, J.K., and Luoma, S.N., 1993, Guidelines for studies of contaminants in biological tissues for the National Water-Quality Assessment Program: U.S. Geological Survey Open-File Report 92-494, 69 p.

Davis, D., and Johnson, A., 1994, Washington State Pesticide Monitoring Program--reconnaissance sampling of fish tissue and sediments (1992): Olympia, Wash., Washington State Department of Ecology, publication no. 94-194.

Eisler, R., 1987, Chromium hazards to fish wildlife, and invertebrates--a synoptic review: U.S. Fish and Wildlife Service, Biological Report 85(1.6), $60 \mathrm{p}$

Goyer, R.A., 1986, Toxic effects of metals, in Klaassen, C.D., Amdur, M.O., and Doull, J., eds., Cassarett and Doull's toxicology--the basic science of poisons: New York, Macmillan Publishing Company, p. 582-635.

Gurtz, M.E., 1994, Design of biological components of the National Water-Quality Assessment (NAWQA) Program, chap. 15, in Loeb, S.L., and Spacie, A., eds., Biological Monitoring of Aquatic Systems: Boca Raton, Fla., Lewis Publishers, p. 323-354.

Heinz, G.H., 1979, Methyimercury--reproductive and behavioral effects on three generations of mallard ducks: Journal of Wildlife Management, v. 43, p. 394-401.

Khera, K.S., 1979, Teratogenic and genetic effects of mercury toxicity, in Nriagu, J.O., ed., The Biogeochemistry of Mercury in the Environment: New York, Elsevier/North-Holland Biomedical Press, p. 501-518. 
Kosalwat, P., and Knight, A.W., 1987, Chronic toxicity of copper to a partial life cycle of the midge, Chironomus decorus: Archives of Environmental Contamination and Toxicology, v. 16, p. 283-290.

Maddock, B.G., and Taylor, D., 1980, The acute toxicity and bioaccumulation of some lead alkyl compounds in marine animals, in Branica, M., and Konrad, Z., eds., Lead in the Marine Environment: Oxford, England, Pergamon Press, p. 233-261.

Malins, D.C., McCain, B.B., Brown, D.W., Sparks, A.K., and Hodgins, H.O., 1980, Chemical contaminants and biological abnormalities in central and southern Puget Sound: National Oceanic and Atmospheric Administration, Office of Marine Pollution Assessment, NOAA Technical Memorandum OMPA-2, $295 \mathrm{p}$.

Malins, D.C., McCain, B.B., Brown, D.W., Chan, S.L., Myers, M.S., Landah, J.T., Prohaska, P.G., Friedman, A.J., Phohdes, L.D., Burrows, D.G., Gronlund, W.D., and Hodgins, H.O., 1984, Chemical pollutants in sediments and diseases of bottom-dwelling fish in Puget Sound: Washington Environmental Science and Technology, v. 18, p. 705-713.

March, B.E., Poon, R., and Chu, S., 1983, The dynamics of ingested methylmercury in growing and laying chickens: Poultry Science, v. 62, p. 1,000-1,009.

Mayer, F.L., and Ellersieck, M.R., 1986, Manual of acute toxicity--interpretation and data base for 410 chemicals and 66 species of freshwater animals: Washington, D.C., U.S. Fish and Wildlife Service, Resource publication no. $160,506 \mathrm{p}$.

McCain, B.B., Malins, D.C., Krahn, M.M., Brown, D.W., Gronlund, W.D., Moore, L.K., and Chan, S-L., 1990, Uptake of aromatic and chlorinated hydrocarbons by juvenile chinook salmon (Oncorhynchus tshawytscha) in an urban esturary: Archives of. Environmental Contamination and Toxicology, v. 19, p. 10-16.

Moriarty, F., 1988, Ecotoxicology--The study of pollutants in ecosystems: New York, Academic Press, Inc., $289 \mathrm{p}$.
National Academy of Sciences and National Academy of Engineering, 1973, Water quality criteria, 1972: Washington, D.C., U.S. Government Printing Office, $594 \mathrm{p}$.

Newell, A.J., Johnson, D.W., and Allen, L.K., 1987, Niagara River biota contamination project--fish flesh criteria for piscivorous wildlife: New York State Department of Environmental Conservation, Division of Fish and Wildlife, Bureau of Environmental Protection Technical Report 87-3, 182 p.

Pimental, D., 1971, Ecologic effects of pesticides on non-target species: Washington, D.C., U.S. Government Printing Office, report to Executive Office of the President, Office of Science and Technology, p. 20-23.

Puget Sound Water Quality Authority, 1988, State of the Sound 1988 report: Olympia, Wash., Puget Sound Water Quality Authority, $225 \mathrm{p}$.

Puget Sound Water Quality Authority, 1992, State of the Sound 1992 report: Olympia, Wash., Puget Sound Water Quality Authority, $71 \mathrm{p}$.

Puget Sound Water Quality Authority, 1995, 1994 Puget Sound Update-Fifth annual report of the Puget Sound Ambient Monitoring Program: Olympia, Wash., Puget Sound Water Quality Authority, 122 p.

Rand, G.M., and Petrocelli, S.R., 1985, Fundamentals of aquatic toxicology: New York, Hemisphere Publishing Corporation, $666 \mathrm{p}$.

Rand, G.M., Wells, P.G., and McCarty, L.S., 1995, Introduction to aquatic toxicology, in Rand, G.M., ed., Fundamentals of Aquatic Toxicology: Washington, D.C., Taylor and Francis, p. 3-70.

Saunders, R.L., and Sprague, J.B., 1967, Effect of copper-zinc mining pollution on a spawning migration of Atlantic salmon: Water Resources, v.1, p. 419-432.

Schmitt, C.J., Ludke, J.L., and Walsh, D.F., 1981, Organochlorine residues in fish--National Pesticide Monitoring Program, 1970-74: Pesticide Monitoring Journal, v. 14, no. 4, p. 136-206. 
Schmitt, C.J., Dwyer, F.J., and Finger, S.E., 1984, Bioavailability of $\mathrm{Pb}$ and $\mathrm{Zn}$ form mine tailings as indicated by erythrocyte gamma-aminolevulinic acid dehydratase (ALA-D) activity in suckers (Pisces: Catostomidae): Canadian Journal of Fisheries and Aquatic Science, v. 41, p. 1,030-1,040.

Schmitt, C.J., and Brumbaugh, W.G., 1990, National Contamination Biomonitoring Program---concentrations of arsenic, cadmium, copper, lead, mercury, selenium, and zinc in U.S. freshwater fish, 19761984: Archives of Environmental Contamination and Toxicology, v. 19, p. 731-747.

Schmitt, C.J., Zajicek, J.L., and Peterman, P.H., 1990, National Contaminant Biomonitoring Program-residues of organochlorine chemicals in U.S. freshwater fish, 1976-1984: Archives of Environmental Contamination and Toxicology, v. 19, p. 748-781.

Sprague, J.B., 1964, Avoidance of copper-zinc solutions by young salmon in the laboratory: Journal of the Water Pollution Control Federation, v. 36, p. 990-1,004.

Stein, J.E., Hom, T., Collier, T.K., Brown, D.W., and Varanasi, U., 1995, Contaminant exposure and biochemical effects in outmigrant juvenile chinook salmon from urban and non-urban estuaries of Puget Sound, Washington: Environ. Tox. Chem., v. 14, p. 1,019-1,029.
Swartz, R.C., Deben, W.A., Sercu, K.A., and Lamberson, J.O., 1982, Sediment toxicity and the distribution of amphipods in Commencement Bay, Washington, USA: Mar. Pollut. Bull., v. 13, p. 359-364.

U.S. Environmental Protection Agency, 1989, Assessing human health risks from chemically contaminated fish and shellfish: Washington, D.C., U.S. Environmental Protection Agency, Office of Marine and Estuarine Protection, Office of Water Regulations and Standards, report EPA-503/8-89-002, 90 p., 8 apps.

U.S. Environmental Protection Agency, 1992, National study of chemical residues in fish: Washington, D.C., U.S. Environmental Protection Agency, Office of Science and Technology, 2 v. (EPA 823-R92-008a, unpaginated, 2 apps.; EPA-823-r-92-008b, 2 apps., unpaginated).

U.S. Environmental Protection Agency, 1994, Draft--the national sediment inventory, compilation of data: Washington, D.C., Office of Science and Technology, Standards and Applied Science Division, $30 \mathrm{p}$.

Walsh, D.F., Berger, B.L., and Bean, J.R., 1977, Mercury, arsenic, lead, cadmium, and selenium residues in fish, 1971-73--National Pesticide monitoring Program: Pesticide Monitoring Journal, v.11, p. 5-34. 
Appendix A.--Summary of trace element concentrations in tissue of fish collected by various agencies from selected sites in the Puget Sound Basin, 1980-1984

[All concentrations are in micrograms per gram (wet weight); entries in bold typeface are greater than the national baseline geometric mean or maximum for that element (see table 4); samples collected between 1980 and 1983 were compared to the national baseline data collected in 1980 and 1981; samples collected in 1984 were compared to the 1984 national baseline data set; *, a tissue sample greater than the maximum value recorded for that element in either the 1980-81 or 1984 national baseline study (U.S. Environmental Protection Agency, 1994)]

\begin{tabular}{|c|c|c|c|c|c|c|}
\hline $\begin{array}{l}\text { Site number } \\
\text { (figure 12) }\end{array}$ & Location and trace elements sampled & Year & $\begin{array}{l}\text { Number of } \\
\text { samples }\end{array}$ & Minimum & Mean & Maximum \\
\hline 1 & SKAGIT RIVER NEAR MOUNT VERNON & & & & & \\
\hline 1 & ARSENIC & 1982 & 3 & 0.048 & 0.053 & 0.060 \\
\hline 1 & CADMIUM & 1982 & 3 & 0.020 & 0.053 & 0.080 \\
\hline 1 & CHROMIUM & 1982 & 3 & 0.700 & 0.867 & 1.000 \\
\hline $\mathbf{1}$ & COPPER & 1982 & 3 & 1.200 & 1.500 & 1.700 \\
\hline 1 & LEAD & 1982 & 3 & 0.610 & 0.613 & 0.620 \\
\hline 1 & MERCURY & 1982 & 3 & 0.015 & 0.054 & 0.115 \\
\hline 1 & ZINC & 1982 & 3 & 13.300 & 21.933 & 27.000 \\
\hline 1 & ARSENIC & 1984 & 5 & 0.030 & 0.106 & 0.370 \\
\hline 1 & CADMIUM & 1984 & 5 & 0.010 & 0.044 & 0.170 \\
\hline 1 & CHROMIUM & 1984 & 5 & 0.030 & 0.044 & 0.100 \\
\hline 1 & COPPER & 1984 & 5 & 1.300 & 2.460 & 5.800 \\
\hline 1 & LEAD & 1984 & 5 & 0.030 & 0.052 & 0.100 \\
\hline 1 & MERCURY & 1984 & 4 & 0.030 & 0.052 & 0.110 \\
\hline 1 & ZINC & 1984 & 5 & 15.000 & 17.840 & 21.600 \\
\hline 2 & SKAGIT RIVER AT CONCRETE & & & & & \\
\hline 2 & ARSENIC & 1983 & 2 & 0.030 & 0.045 & 0.060 \\
\hline 2 & CADMIUM & 1983 & 2 & 0.040 & 0.045 & 0.050 \\
\hline 2 & CHROMIUM & 1983 & 2 & 0.050 & 0.285 & 0.520 \\
\hline 2 & COPPER & 1983 & 2 & 1.300 & 1.400 & 1.500 \\
\hline 2 & LEAD & 1983 & 2 & 0.440 & 0.485 & 0.530 \\
\hline 2 & MERCURY & 1983 & 2 & 0.012 & 0.036 & 0.059 \\
\hline 2 & ZINC & 1983 & 2 & 16.000 & 19.000 & 22.000 \\
\hline 3 & SNOHOMISH RIVER AT SNOHOMISH & & & & & \\
\hline 3 & ARSENIC & 1982 & 4 & 0.008 & 0.024 & 0.044 \\
\hline 3 & CADMIUM & 1982 & 4 & 0.020 & 0.040 & 0.060 \\
\hline 3 & CHROMIUM & 1982 & 4 & 0.200 & 2.475 & 7.000 \\
\hline 3 & COPPER & 1982 & 4 & 1.300 & 1.575 & 1.900 \\
\hline 3 & LEAD & 1982 & 4 & 0.380 & 0.540 & 0.760 \\
\hline
\end{tabular}


Appendix A.--Summary of trace element concentrations in tissue of fish collected by various agencies from selected sites in the Puget Sound Basin, 1980-1984--continued

\begin{tabular}{|c|c|c|c|c|c|c|}
\hline $\begin{array}{l}\text { Site number } \\
\text { (figure 12) }\end{array}$ & Location and trace elements sampled & Year & $\begin{array}{l}\text { Number of } \\
\text { samples }\end{array}$ & Minimum & Mean & Maximum \\
\hline 3 & MERCURY & 1982 & 4 & 0.033 & 0.040 & 0.050 \\
\hline 3 & ZINC & 1982 & 4 & 12.100 & 22.625 & 30.900 \\
\hline 4 & CEDAR RIVER NEAR LANDSBURG & & & & & \\
\hline 4 & ARSENIC & 1983 & 1 & 0.020 & 0.020 & 0.020 \\
\hline 4 & CADMIUM & 1983 & 1 & 0.080 & 0.080 & 0.080 \\
\hline 4 & CHROMIUM & 1983 & 1 & 0.069 & 0.069 & 0.069 \\
\hline 4 & COPPER & 1983 & 1 & 1.370 & 1.370 & 1.370 \\
\hline 4 & LEAD & 1983 & 1 & $\mathbf{0 . 1 7 0}$ & 0.170 & 0.170 \\
\hline 4 & MERCURY & 1983 & 1 & 0.006 & 0.006 & 0.006 \\
\hline 4 & ZINC & 1983 & 1 & 23.900 & 23.900 & 23.900 \\
\hline 5 & $\begin{array}{l}\text { DUWAMISH RIVER AT ALLENTOWN } \\
\text { BRIDGE }\end{array}$ & & & & & \\
\hline 5 & ARSENIC & 1983 & 1 & 0.090 & 0.090 & 0.090 \\
\hline 5 & CADMIUM & 1983 & 1 & 0.030 & 0.030 & 0.030 \\
\hline 5 & CHROMIUM & 1983 & 1 & 0.520 & 0.520 & 0.520 \\
\hline 5 & COPPER & 1983 & 1 & 1.400 & 1.400 & 1.400 \\
\hline 5 & LEAD & 1983 & 1 & 0.800 & 0.800 & 0.800 \\
\hline 5 & MERCURY & 1983 & I & 0.044 & 0.044 & 0.044 \\
\hline 5 & $\mathrm{ZINC}$ & 1983 & 1 & 14.000 & 14.000 & 14.000 \\
\hline 5 & ARSENIC & 1984 & 6 & 0.030 & 0.030 & 0.030 \\
\hline 5 & CADMIUM & 1984 & 6 & 0.010 & 0.143 & $0.430^{*}$ \\
\hline 5 & CHROMIUM & 1984 & 6 & 0.030 & 0.070 & 0.200 \\
\hline 5 & COPPER & 1984 & 6 & 1.000 & 6.333 & $24.600^{*}$ \\
\hline 5 & LEAD & 1984 & 6 & 0.030 & 0.065 & 0.100 \\
\hline 5 & MERCURY & 1984 & 4 & 0.040 & 0.212 & 0.530 \\
\hline 5 & ZINC & 1984 & 6 & 11.400 & 19.867 & 27.300 \\
\hline 7 & NISQUALLY RIVER AT NISQUALLY & & & & & \\
\hline 7 & ARSENIC & 1982 & 4 & 0.002 & 0.018 & 0.042 \\
\hline 7 & CADMIUM & 1982 & 4 & 0.020 & 0.035 & 0.060 \\
\hline 7 & CHROMIUM & 1982 & 4 & 0.100 & 0.675 & 1.100 \\
\hline 7 & COPPER & 1982 & 4 & 1.200 & 1.425 & 1.700 \\
\hline
\end{tabular}


Appendix A.--Summary of trace element concentrations in tissue of fish collected by various agencies from selected sites in the Puget Sound Basin, 1980-1984--continued

\begin{tabular}{|c|c|c|c|c|c|c|}
\hline $\begin{array}{l}\text { Site number } \\
\text { (figure 12) }\end{array}$ & Location and trace elements sampled & Year & $\begin{array}{l}\text { Number of } \\
\text { samples }\end{array}$ & Minimum & Mean & Maximum \\
\hline 7 & LEAD & 1982 & 4 & 0.430 & 0.692 & 1.140 \\
\hline 7 & MERCURY & 1982 & 4 & 0.040 & 0.062 & 0.093 \\
\hline 7 & ZINC & 1982 & 4 & 17.600 & 22.325 & 27.800 \\
\hline 8 & $\begin{array}{l}\text { CEDAR R. NR LANDSBURG (SEATTLE } \\
\text { D.W. INTAKE) }\end{array}$ & & & & & \\
\hline 8 & ANTIMONY & 1980 & 1 & 0.060 & 0.060 & 0.060 \\
\hline 8 & ARSENIC & 1980 & 1 & 0.060 & 0.060 & 0.060 \\
\hline 8 & BERYLLIUM & 1980 & 1 & 0.007 & 0.007 & 0.007 \\
\hline 8 & CADMIUM & 1980 & 1 & 0.040 & 0.040 & 0.040 \\
\hline 8 & CHROMIUM & 1980 & 1 & 0.450 & 0.450 & 0.450 \\
\hline 8 & COPPER & 1980 & 1 & 1.100 & 1.100 & 1.100 \\
\hline 8 & LEAD & 1980 & 1 & 2.400 & 2.400 & $2.400^{*}$ \\
\hline 8 & MERCURY & 1980 & 1 & 0.050 & 0.050 & 0.050 \\
\hline 8 & NICKEL & 1980 & 1 & 0.400 & 0.400 & 0.400 \\
\hline 8 & SELENIUM & 1980 & 1 & 0.200 & 0.200 & 0.200 \\
\hline 8 & SILVER & 1980 & 1 & 0.012 & 0.012 & 0.012 \\
\hline 8 & THALLIUM & 1980 & 1 & 0.070 & 0.070 & 0.070 \\
\hline 8 & ZINC & 1980 & 1 & 9.400 & 9.400 & 9.400 \\
\hline 9 & SNOHOMISH RIVER AT MONROE & & & & & \\
\hline 9 & MERCURY & 1984 & 2 & 0.200 & 0.360 & $0.520^{*}$ \\
\hline 10 & PUYALLUP RIVER AT PUYALLUP & & & & & \\
\hline 10 & MERCURY & 1984 & 2 & 0.100 & 0.145 & 0.190 \\
\hline
\end{tabular}


Appendix B.--Summary of synthetic organic compound concentrations in tissue of fish collected by various agencies from selected sites in the Puget Sound Basin, 1980-1992

[All concentrations are in micrograms per kilograms (wet weight); values and significant figures taken directly from Davis and Johnson (1994) and U.S. Environmental Protection Agency (1994); entries in bold typeface are greater than the national baseline geometric mean or maximum for that compound (see table 5); samples collected between 1980 and 1983 were compared to the national baseline data collected in 1980 and 1981; samples collected between 1984 and 1992 were compared to the 1984 national baseline data set; *, a tissue sample greater than the National Academy of Sciences/National Academy of Engineering recommended maximum tissue concentrations; +, a tissue sample greater than the New York State Department of Environmental Conservation fish flesh criteria; , analyte was positively identified, but the value is an estimate; \#, the analyte is present, but the value is an estimate]

\begin{tabular}{|c|c|c|c|c|c|c|}
\hline $\begin{array}{l}\text { Site number } \\
\text { (figure 12) }\end{array}$ & Location and organic compound sampled & Year & $\begin{array}{l}\text { Number of } \\
\text { samples }\end{array}$ & Minimum & Mean & Maximum \\
\hline 1 & SKAGIT RIVER NEAR MOUNT VERNON & & & & & \\
\hline 1 & BHC-alpha & 1982 & 2 & 3 & 5 & 7 \\
\hline 1 & TOTAL DDT & 1982 & 2 & 12 & 14 & 16 \\
\hline 1 & METHOXYCHLOR & 1982 & 2 & 10 & 10 & 10 \\
\hline 1 & p,p' DDE & 1982 & 2 & 12 & 14 & 16 \\
\hline 1 & PCB - 1254 & 1982 & 2 & 38 & 43 & 47 \\
\hline 1 & PCB - 1260 & 1982 & 2 & 10 & 10 & 10 \\
\hline 1 & PCBS TOTAL & 1982 & 2 & 48 & 53 & 57 \\
\hline 1 & PCP (PENTACHLOROPHENOL) & 1982 & 2 & 4 & 7 & 10 \\
\hline 1 & BHC-alpha & 1984 & 4 & 1 & 3 & 4 \\
\hline 1 & TOTAL DDT & 1984 & 4 & 64 & 188 & $369+$ \\
\hline 1 & $o, p^{\prime}$ DDT & 1984 & 3 & 11 & 18 & 24 \\
\hline 1 & $o, p^{\prime}$ DDE & 1984 & 3 & 11 & 30 & 55 \\
\hline 1 & $\mathrm{p}, \mathrm{p}^{\prime}$ DDD & 1984 & 3 & 5 & 35 & 70 \\
\hline 1 & p,p' DDT & 1984 & 3 & 19 & 55 & 100 \\
\hline 1 & p,p' DDE & 1984 & 4 & 18 & 50 & 120 \\
\hline 1 & PCB - 1260 & 1984 & 4 & 10 & 56 & 150 \\
\hline 1 & PCP (PENTACHLOROPHENOL) & 1984 & 4 & 2 & 102 & 360 \\
\hline 2 & SKAGIT RIVER AT CONCRETE & & & & & \\
\hline 2 & ALDRIN & 1983 & 1 & 1 & 1 & 1 \\
\hline 2 & BHC-alpha & 1983 & 4 & 2 & 6 & 9 \\
\hline 2 & TOTAL DDT & 1983 & 6 & 12 & 18 & 23 \\
\hline 2 & p,p' DDD & 1983 & 4 & 3 & 4 & 5 \\
\hline 2 & $\mathrm{p}, \mathrm{p}^{\prime}$ DDT & 1983 & 1 & 8 & 8 & 8 \\
\hline 2 & $\mathrm{p}, \mathrm{p}^{\prime} \mathrm{DDE}$ & 1983 & 6 & 1 & 6 & 10 \\
\hline
\end{tabular}


Appendix B.--Summary of synthetic organic compound concentrations in tissue of fish collected by various agencies from selected sites in the Puget Sound Basin, 1980-1992--continued

\begin{tabular}{|c|c|c|c|c|c|c|}
\hline $\begin{array}{l}\text { Site number } \\
\text { (figure 12) }\end{array}$ & Location and organic compound sampled & Year & $\begin{array}{l}\text { Number of } \\
\text { samples }\end{array}$ & Minimum & Mean & Maximum \\
\hline 2 & PCB - 1254 & 1983 & 2 & 11 & 24 & 38 \\
\hline 2 & PCBS TOTAL & 1983 & 2 & 11 & 24 & 38 \\
\hline 3 & SNOHOMISH RIVER AT SNOHOMISH & & & & & \\
\hline 3 & BHC-alpha & 1982 & 1 & 5 & 5 & 5 \\
\hline 3 & TOTAL DDT & 1982 & 2 & 37 & 53 & 69 \\
\hline 3 & p,p' DDT & 1982 & 1 & 43 & 43 & 43 \\
\hline 3 & $\mathrm{p}, \mathrm{p}^{\prime} \mathrm{DDE}$ & 1982 & 2 & 24 & 32 & 37 \\
\hline 3 & PCB - 1254 & 1982 & 2 & $240+$ & $280+$ & $320+$ \\
\hline 3 & PCP (PENTACHLOROPHENOL) & 1982 & 2 & 6 & 2,753 & 5,500 \\
\hline 4 & CEDAR RIVER NEAR LANDSBURG & & & & & \\
\hline 4 & BHC-alpha & 1983 & 1 & 0.2 & 0.2 & 0.2 \\
\hline 4 & TOTAL DDT & 1983 & 1 & 22 & 22 & 22 \\
\hline 4 & $\mathrm{p}, \mathrm{p}^{\prime} \mathrm{DDD}$ & 1983 & 1 & 2 & 2 & 2 \\
\hline 4 & $\mathrm{p}, \mathrm{p}$ ' DDT & 1983 & 1 & 4 & 4 & 4 \\
\hline 4 & $\mathrm{p}, \mathrm{p}$ ' DDE & 1983 & 1 & 4 & 4 & 4 \\
\hline 4 & PCB - 1254 & 1983 & 1 & 12 & 12 & 12 \\
\hline 5 & $\begin{array}{l}\text { DUWAMISH RIVER AT ALLENTOWN } \\
\text { BRIDGE }\end{array}$ & & & & & \\
\hline 5 & BHC-alpha & 1983 & 1 & 20 & 20 & 20 \\
\hline 5 & $\mathrm{p}, \mathrm{p}$ ' DDE & 1983 & 1 & 13 & 13 & 13 \\
\hline 5 & PCB - 1254 & 1983 & 1 & 1,600 & 1,600 & 1,600 \\
\hline 5 & BHC-alpha & 1984 & 4 & 59 & $228 *$ & $460^{*}$ \\
\hline 5 & TOTAL DDT & 1984 & 4 & $813+$ & $1,577_{+}$ & $2,520^{*}+$ \\
\hline 5 & $o, p^{\prime}$ DDT & 1984 & 4 & 73 & 191 & $330+$ \\
\hline 5 & $o, p^{\prime}$ DDE & 1984 & 2 & 120 & 185 & $250+$ \\
\hline 5 & $\mathrm{p}, \mathrm{p}^{\prime} \mathrm{DDD}$ & 1984 & 4 & 160 & $265+$ & $340+$ \\
\hline 5 & $\mathrm{p}, \mathrm{p}^{\prime}$ DDT & 1984 & 4 & $300+$ & $508+$ & $970+$ \\
\hline 5 & $\mathrm{p}, \mathrm{p}^{\prime} \mathrm{DDE}$ & 1984 & 4 & 160 & $428+$ & $630+$ \\
\hline 5 & PCB - 1260 & 1984 & 4 & $420+$ & $593+$ & $760+$ \\
\hline 5 & PCP (PENTACHLOROPHENOL) & 1984 & 4 & 10 & 84 & 170 \\
\hline
\end{tabular}


Appendix B.--Summary of synthetic organic compound concentrations in tissue of fish collected by various agencies from selected sites in the Puget Sound Basin, 1980-1992--continued

\begin{tabular}{|c|c|c|c|c|c|c|}
\hline $\begin{array}{l}\text { Site number } \\
\text { (figure 12) }\end{array}$ & Location and organic compound sampled & Year & $\begin{array}{l}\text { Number of } \\
\text { samples }\end{array}$ & Minimum & Mean & Maximum \\
\hline 6 & PUYALLUP R AT MERIDIAN ST BRIDGE & & & & & \\
\hline 6 & BHC-alpha & 1980 & 1 & 5 & 5 & 5 \\
\hline 6 & CHLORDANE, alpha & 1980 & 1 & 11 & 11 & 11 \\
\hline 6 & CHLORDANE, gamma & 1980 & 1 & 12 & 12 & 12 \\
\hline 6 & TOTAL DDT & 1980 & 1 & 64 & 64 & 64 \\
\hline 6 & BHC-gamma & 1980 & 1 & 1 & 1 & 1 \\
\hline 6 & $\mathrm{p}, \mathrm{p}$ ' DDD & 1980 & 1 & 29 & 29 & 29 \\
\hline 6 & p,p' DDE & 1980 & 1 & 35 & 35 & 35 \\
\hline 6 & PCBS TOTAL & 1980 & 1 & $290+$ & $290+$ & $290+$ \\
\hline 6 & CHLORDANE, alpha & 1981 & 1 & 4 & 4 & 4 \\
\hline 6 & CHLORDANE, gamma & 1981 & 1 & 7 & 7 & 7 \\
\hline 6 & CHLORDANE-NONACHLOR,trans & 1981 & 1 & 7 & 7 & 7 \\
\hline 6 & TOTAL DDT & 1981 & 1 & 66 & 66 & 66 \\
\hline 6 & DIELDRIN & 1981 & 1 & 1 & 1 & 1 \\
\hline 6 & HEXACHLOROBENZENE & 1981 & 1 & 36 & 36 & 36 \\
\hline 6 & o,p' DDT & 1981 & 1 & 2 & 2 & 2 \\
\hline 6 & p,p' DDD & 1981 & 1 & 20 & 20 & 20 \\
\hline 6 & p,p' DDT & 1981 & 1 & 16 & 16 & 16 \\
\hline 6 & p,p' DDE & 1981 & 1 & 28 & 28 & 28 \\
\hline 6 & PCBS TOTAL & 1981 & 1 & $160+$ & $160+$ & $160+$ \\
\hline 7 & NISQUALLY RIVER AT NISQUALLY & & & & & \\
\hline 7 & BHC-alpha & 1982 & 2 & 4 & 10 & 15 \\
\hline 7 & TOTAL DDT & 1982 & 2 & 36 & 36 & 36 \\
\hline 7 & p,p' DDD & 1982 & 2 & 9 & 10 & 11 \\
\hline 7 & p,p' DDT & 1982 & 2 & 17 & 21 & 25 \\
\hline 7 & p,p' DDE & 1982 & 2 & 10 & 17 & 24 \\
\hline 7 & PCP (PENTACHLOROPHENOL) & 1982 & 2 & 4 & 5 & 5 \\
\hline 8 & $\begin{array}{c}\text { CEDAR R. NR LANDSBURG (SEATTLE } \\
\text { D.W. INTAKE) }\end{array}$ & & & & & \\
\hline 8 & BHC-alpha & 1980 & 1 & 24 & 24 & 24 \\
\hline 8 & BIS(2-ETHYLHEXYL)PHTHALATE & 1980 & 1 & 700 & 700 & 700 \\
\hline 8 & DI-N-BUTYL PHTHALATE & 1980 & 1 & 200 & 200 & 200 \\
\hline
\end{tabular}


Appendix B.--Summary of synthetic organic compound concentrations in tissue of fish collected by various agencies from selected sites in the Puget Sound Basin, 1980-1992--continued

\begin{tabular}{|c|c|c|c|c|c|c|}
\hline $\begin{array}{l}\text { Site number } \\
\text { (figure 12) }\end{array}$ & Location and organic compound sampled & Year & $\begin{array}{l}\text { Number of } \\
\text { samples }\end{array}$ & Minimum & Mean & Maximum \\
\hline 8 & DIETHYL PHTHALATE & 1980 & 1 & 1,400 & 1,400 & 1,400 \\
\hline 8 & BHC-gamma & 1980 & 1 & 8 & 8 & 8 \\
\hline 8 & METHYLENE CHLORIDE & 1980 & 1 & 300 & 300 & 300 \\
\hline 9 & SNOHOMISH @ MONROE & & & & & \\
\hline 9 & CHLORDANE, alpha & 1984 & 1 & 3 & 3 & 3 \\
\hline 9 & $\begin{array}{l}\text { HEPTACHLORODIBENZO-P- } \\
\text { DIOXIN,1234678,TIS }\end{array}$ & 1984 & 1 & $0.01 \#$ & $0.01 \#$ & $0.01 \#$ \\
\hline 9 & HEXACHLORODIBENZOFURAN,123478- & 1984 & 1 & $0.001 \#$ & $0.001 \#$ & $0.001 \#$ \\
\hline 9 & HEXACHLORODIBENZOFURAN,234678- & 1984 & 1 & $0.001 \#$ & $0.001 \#$ & $0.001 \#$ \\
\hline 9 & NONACHLOR, trans & 1984 & 1 & 11 & 11 & 11 \\
\hline 9 & p,p' DDE & 1984 & 1 & 42 & 42 & 42 \\
\hline 9 & PCBS TOTAL & 1984 & 1 & $206+$ & $206+$ & $206+$ \\
\hline 9 & TETRACHLOROBIPHENYL,TOT & 1984 & 1 & 22 & 22 & 22 \\
\hline 10 & PUYALLUP RIVER @ PUYALLUP & & & & & \\
\hline 10 & BHC-alpha & 1984 & 1 & 8 & 8 & 8 \\
\hline 10 & CHLORDANE, alpha & 1984 & 1 & 4 & 4 & 4 \\
\hline 10 & CHLORDANE, gamma & 1984 & 1 & 10 & 10 & 10 \\
\hline 10 & HEPTACHLOROBIPHENYL,TOT & 1984 & 1 & 5 & 5 & 5 \\
\hline 10 & $\begin{array}{l}\text { HEPTACHLORODIBENZO-P- } \\
\text { DIOXIN,1234678,TIS }\end{array}$ & 1984 & 2 & $0.001 \#$ & $0.002 \#$ & $0.002 \#$ \\
\hline 10 & HEPTACHLORODIBENZOFURAN,1234678- & 1984 & 2 & $0.001 \#$ & $0.001 \#$ & $0.001 \#$ \\
\hline 10 & HEXACHLOROBIPHENYLS & 1984 & 1 & 36 & 36 & 36 \\
\hline 10 & HEXACHLORODIBENZO-P-DIOXIN, 123678 & 1984 & 2 & 0.001 & 0.002 & 0.002 \\
\hline 10 & HEXACHLORODIBENZOFURAN,234678- & 1984 & 2 & $0.001 \#$ & $0.001 \#$ & $0.001 \#$ \\
\hline 10 & $p, p^{\prime}$ DDE & 1984 & 1 & 22 & 22 & 22 \\
\hline 10 & PCBS TOTAL & 1984 & 1 & 82 & 82 & 82 \\
\hline 10 & PENTACHLOROBIPHENYL,TOT & 1984 & 1 & 37 & 37 & 37 \\
\hline 10 & TETRACHLOROBIPHENYL, TOT & 1984 & 1 & 4 & 4 & 4 \\
\hline 11 & MERCER SOULGH NEAR BELLEVUE & & & & & \\
\hline 11 & $\mathrm{p}, \mathrm{p}^{\prime} \mathrm{DDE}$ & 1992 & 2 & 15.0 & 79.5 & 144.0 \\
\hline 11 & $\mathrm{p}, \mathrm{p}^{\prime} \mathrm{DDD}$ & 1992 & 2 & $4.4 \sim$ & 40.0 & 75.0 \\
\hline 11 & $\mathrm{p}, \mathrm{p}^{\prime} \mathrm{DDT}$ & 1992 & 2 & $3.5 \sim$ & 10.8 & 18.0 \\
\hline
\end{tabular}


Appendix B.--Summary of synthetic organic compound concentrations in tissue of fish collected by various agencies from selected sites in the Puget Sound Basin, 1980-1992--continued

\begin{tabular}{ccccccc}
\hline $\begin{array}{c}\text { Site number } \\
\text { (figure 12) }\end{array}$ & Location and organic compound sampled & Year & $\begin{array}{c}\text { Number of } \\
\text { samples }\end{array}$ & Minimum & Mean & Maximum \\
\hline 11 & o,p' DDD & 1992 & 1 & 12.0 & 12.0 & 12.0 \\
11 & TOTAL DDT & 1992 & 2 & 23.0 & 136.0 & $249.0+$ \\
11 & DDMU & 1992 & 2 & $3.0 \sim$ & 14.5 & $26.0 \#$ \\
11 & BHC-gamma & 1992 & 1 & $1.1 \sim$ & $1.1 \sim$ & $1.1 \sim$ \\
11 & DICOFOL (KELTHANE) & 1992 & 1 & $1.4 \#$ & $1.4 \#$ & $1.4 \#$ \\
11 & CHLORDENE, alpha & 1992 & 1 & $1.7 \sim$ & $1.7 \sim$ & $1.7 \sim$ \\
11 & CHLORDENE, gamma & 1992 & 1 & $2.7 \sim$ & $2.7 \sim$ & $2.7 \sim$ \\
11 & CHLORDANE, alpha & 1992 & 2 & $2.1 \sim$ & 13.1 & 24.0 \\
11 & CHLORDANE, gamma & 1992 & 2 & $1.3 \sim$ & 5.6 & $10.0 \sim$ \\
11 & NONACHLOR, cis & 1992 & 2 & $0.7 \sim$ & 8.8 & 17.0 \\
11 & NONACHLOR, trans & 1992 & 2 & $3.8 \sim$ & 23.4 & 43.0 \\
11 & OXYCHLORDANE & 1992 & 2 & $0.4 \sim$ & 1.4 & 2.3 \\
11 & CHLORDANE, TOTAL & 1992 & 2 & 8.3 & 52.0 & 96.0 \\
11 & HEXACHLOROBENZENE & 1992 & 1 & $2.9 \sim$ & $2.9 \sim$ & $2.9 \sim$ \\
11 & PENTACHLOROANISOLE(PCA) & 1992 & 2 & $0.6 \sim$ & 3.4 & $6.2 \sim$ \\
11 & PCB - 1254 & 1992 & 2 & $20.0 \sim$ & 62.0 & $104.0 \sim$ \\
11 & PCB - 1260 & 1992 & 2 & $31.0 \sim$ & 153.0 & 275.0 \\
11 & PCB, TOTAL & 1992 & 2 & 51.0 & $215.0+$ & $379.0+$ \\
& & & & & \\
\hline
\end{tabular}




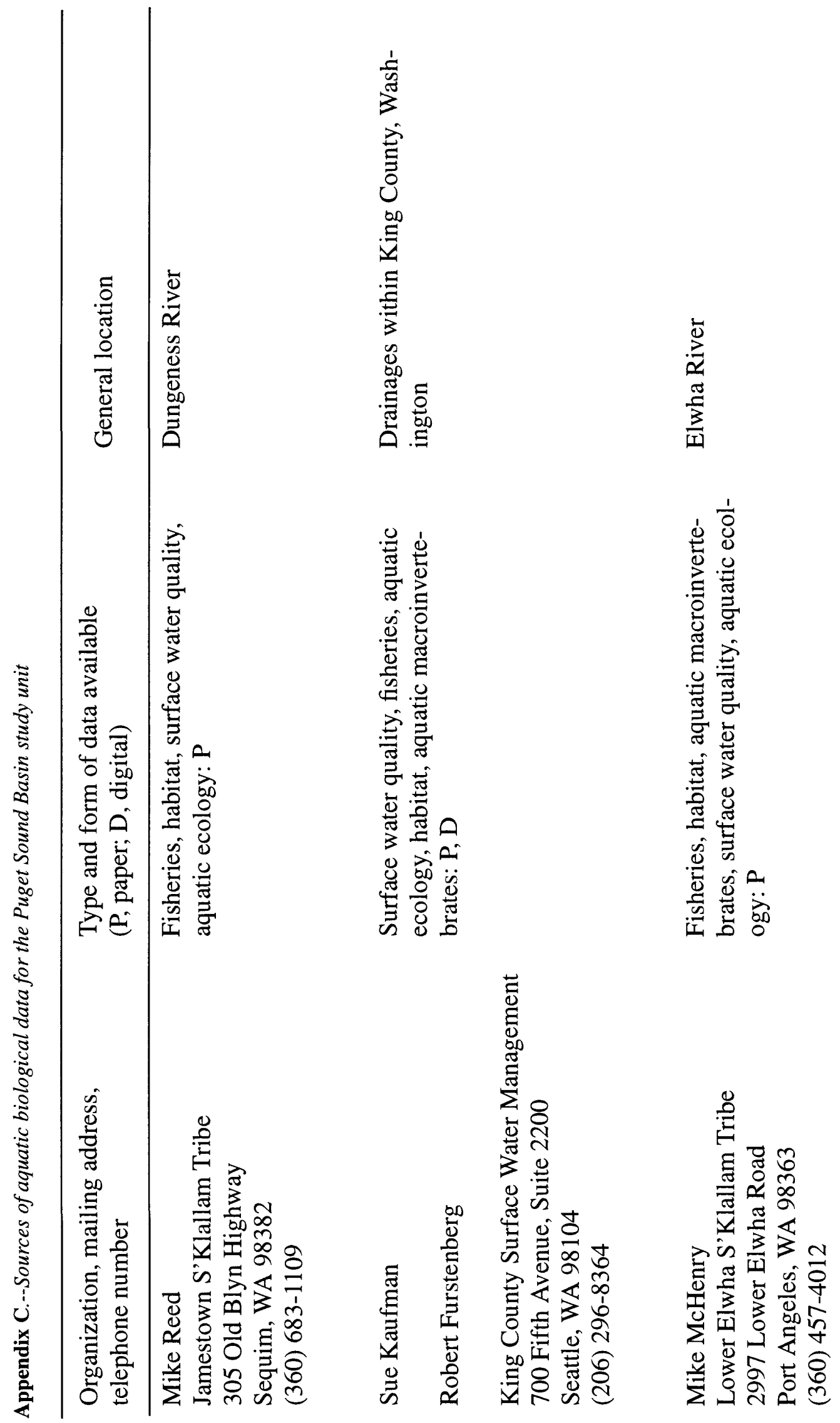




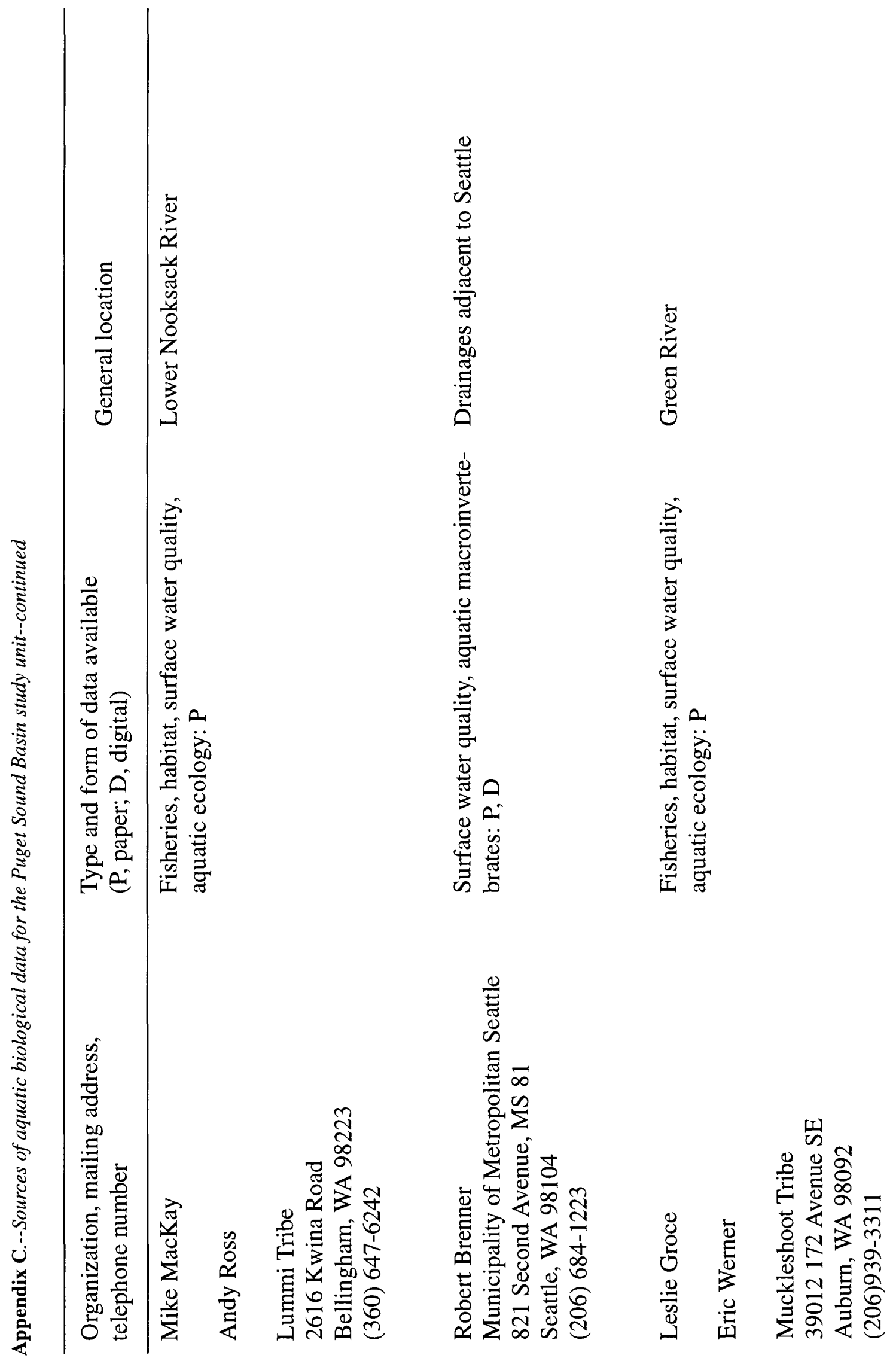




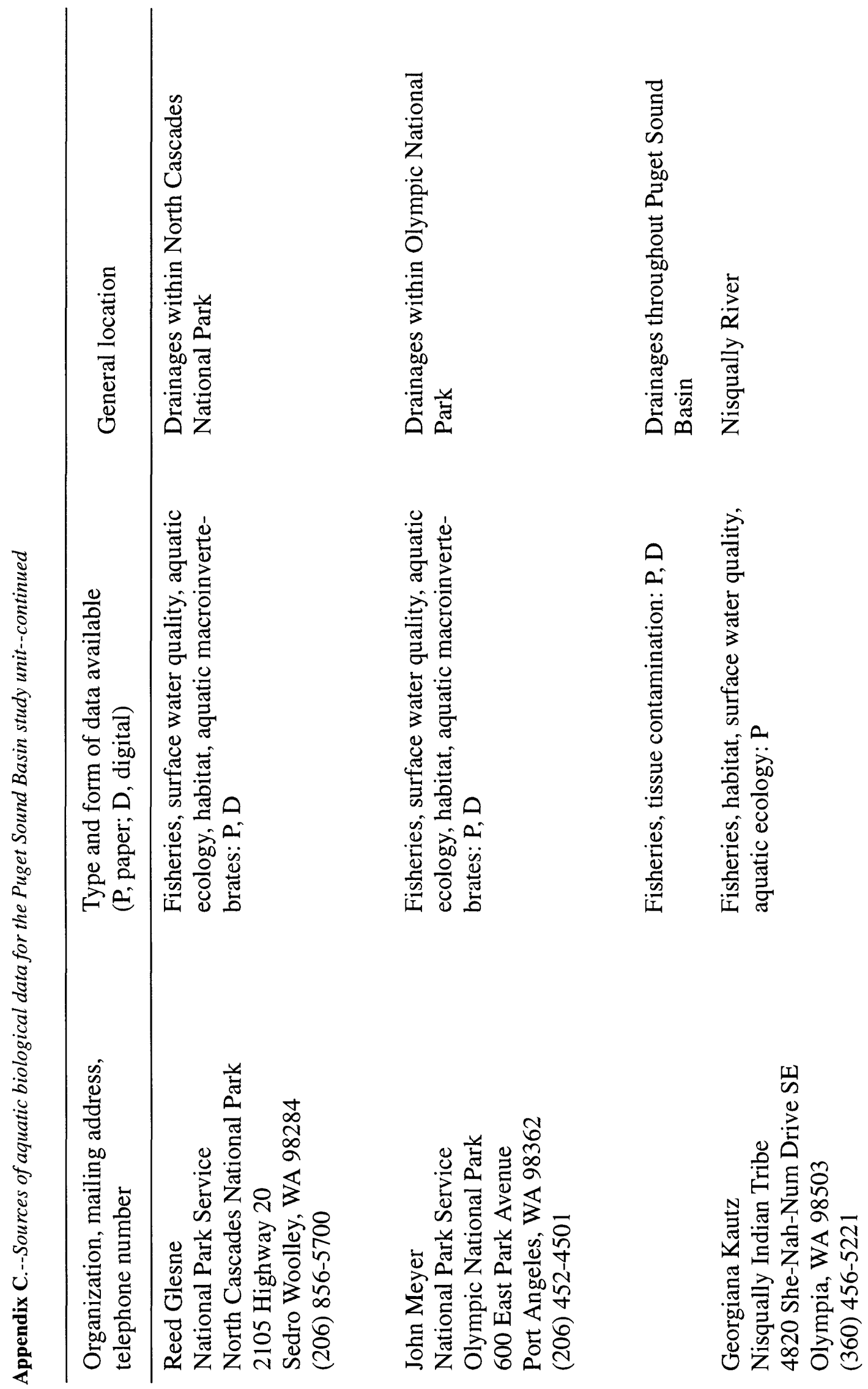




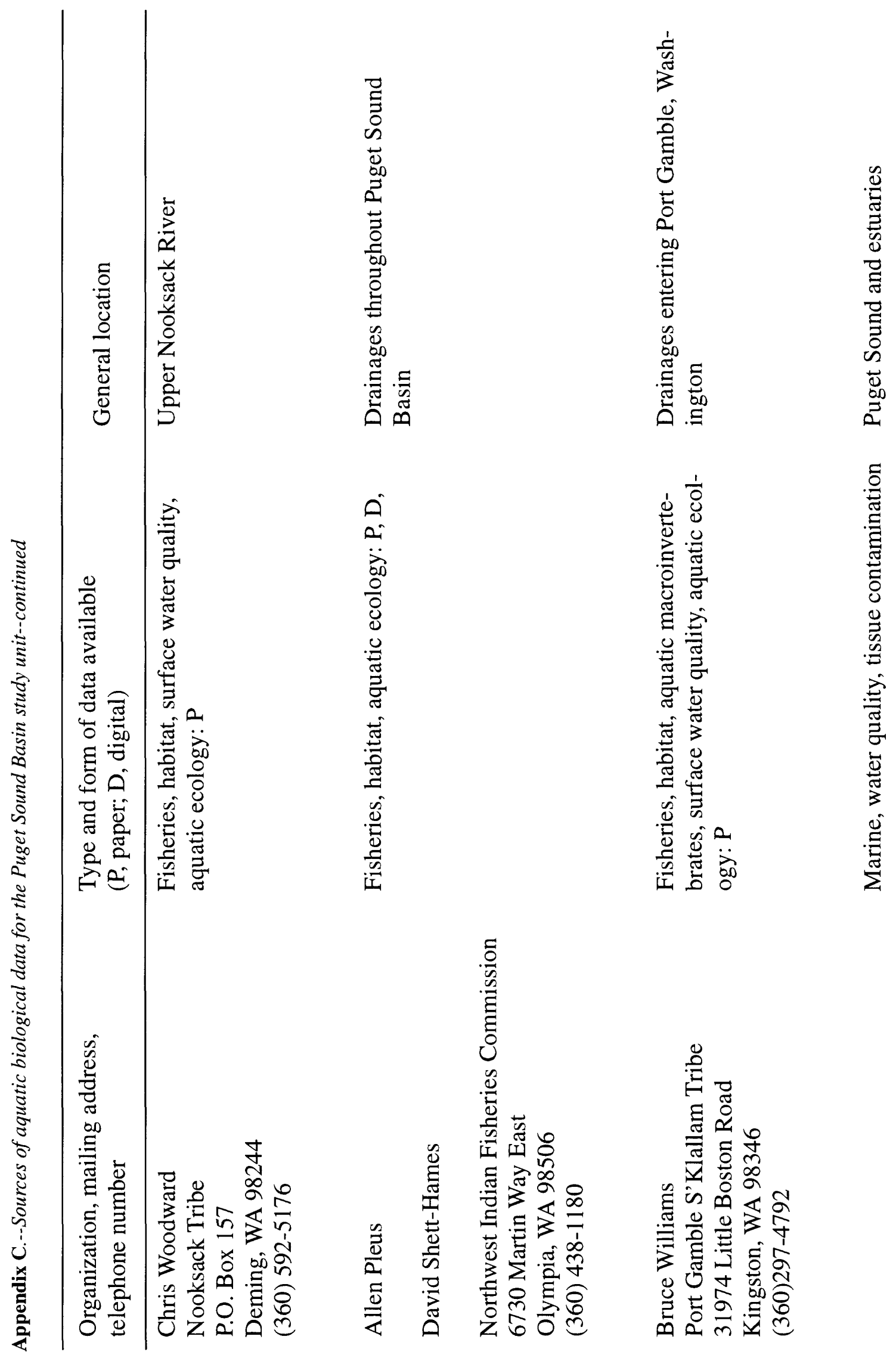




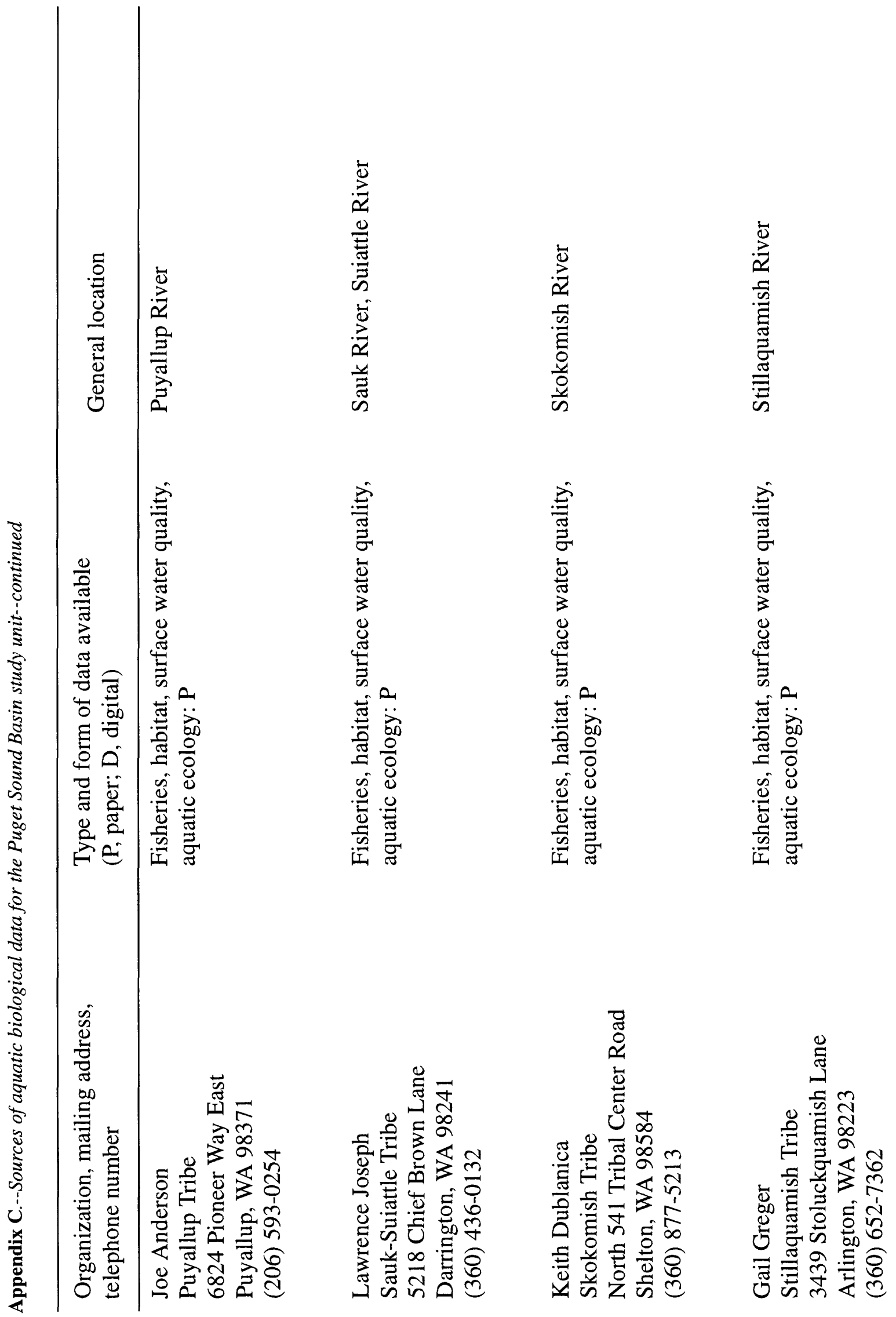




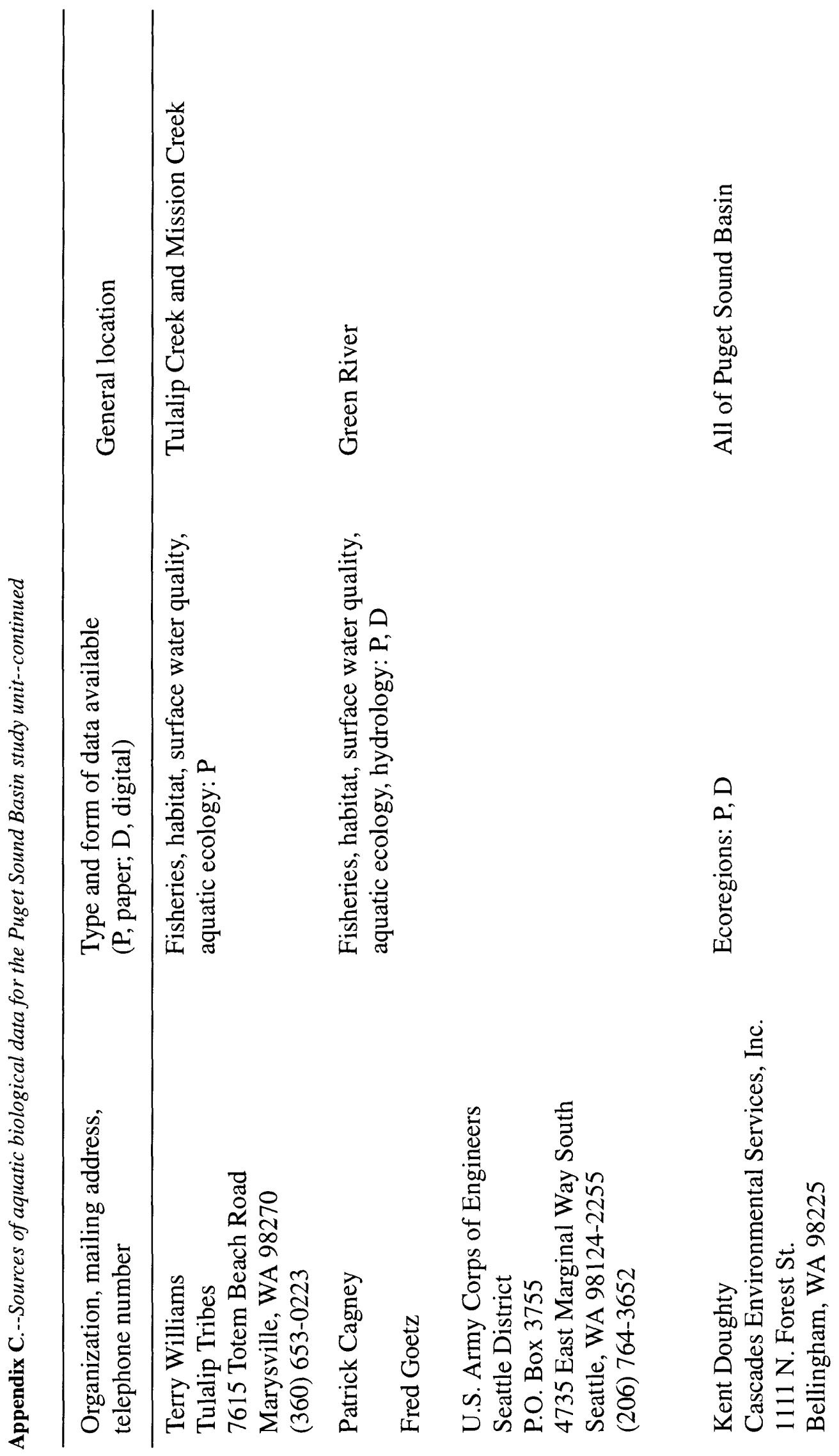



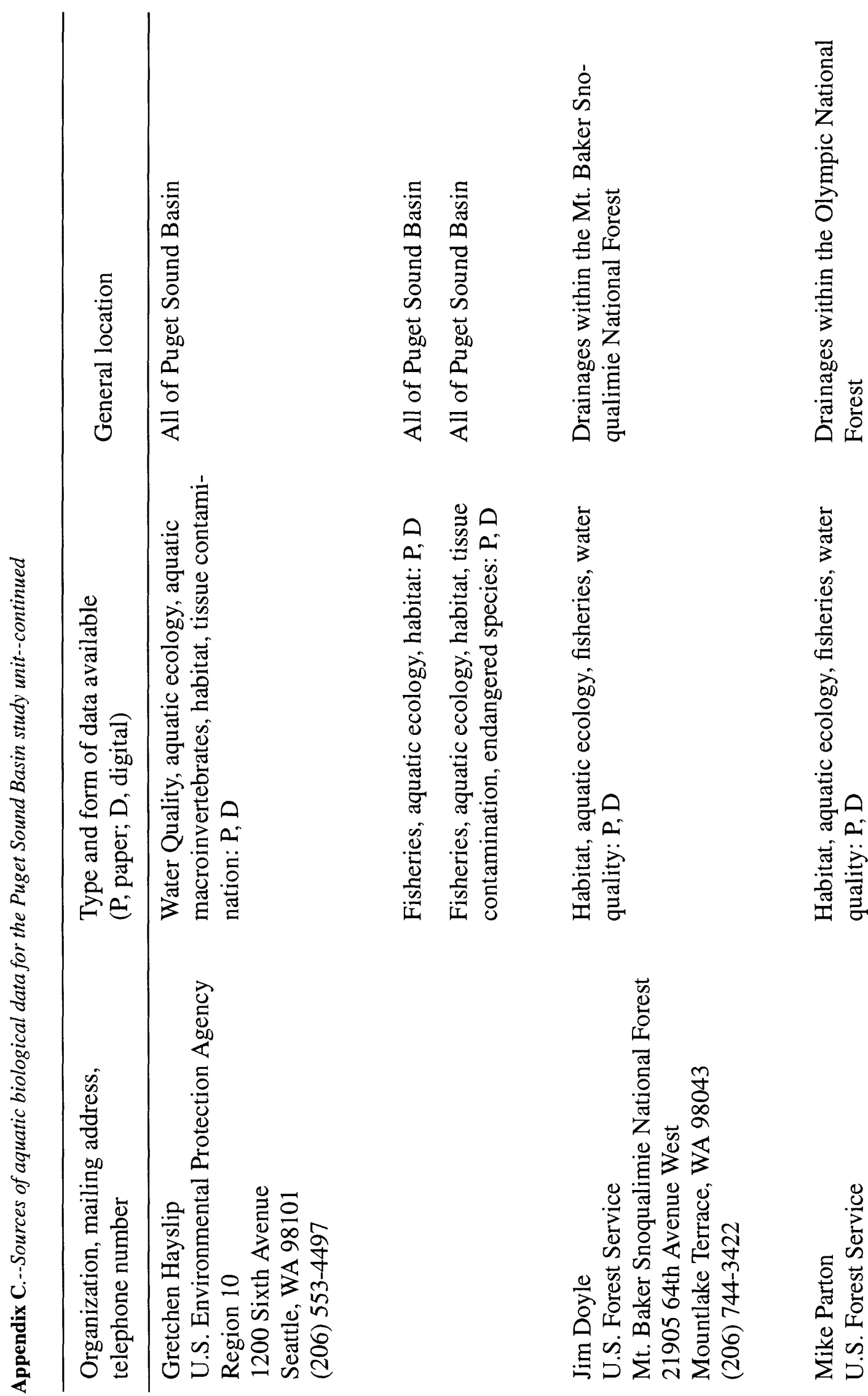

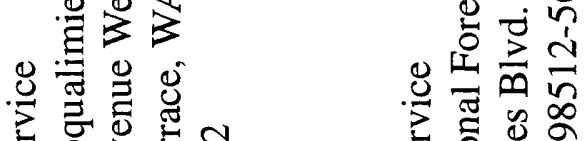

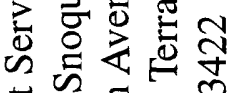

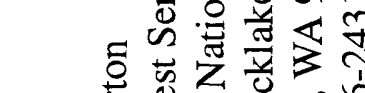

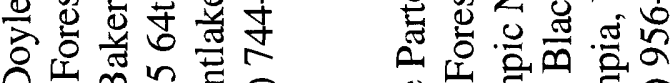

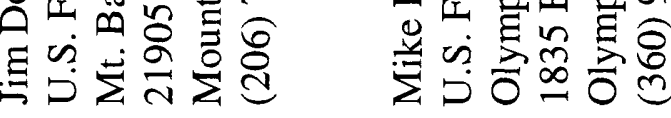




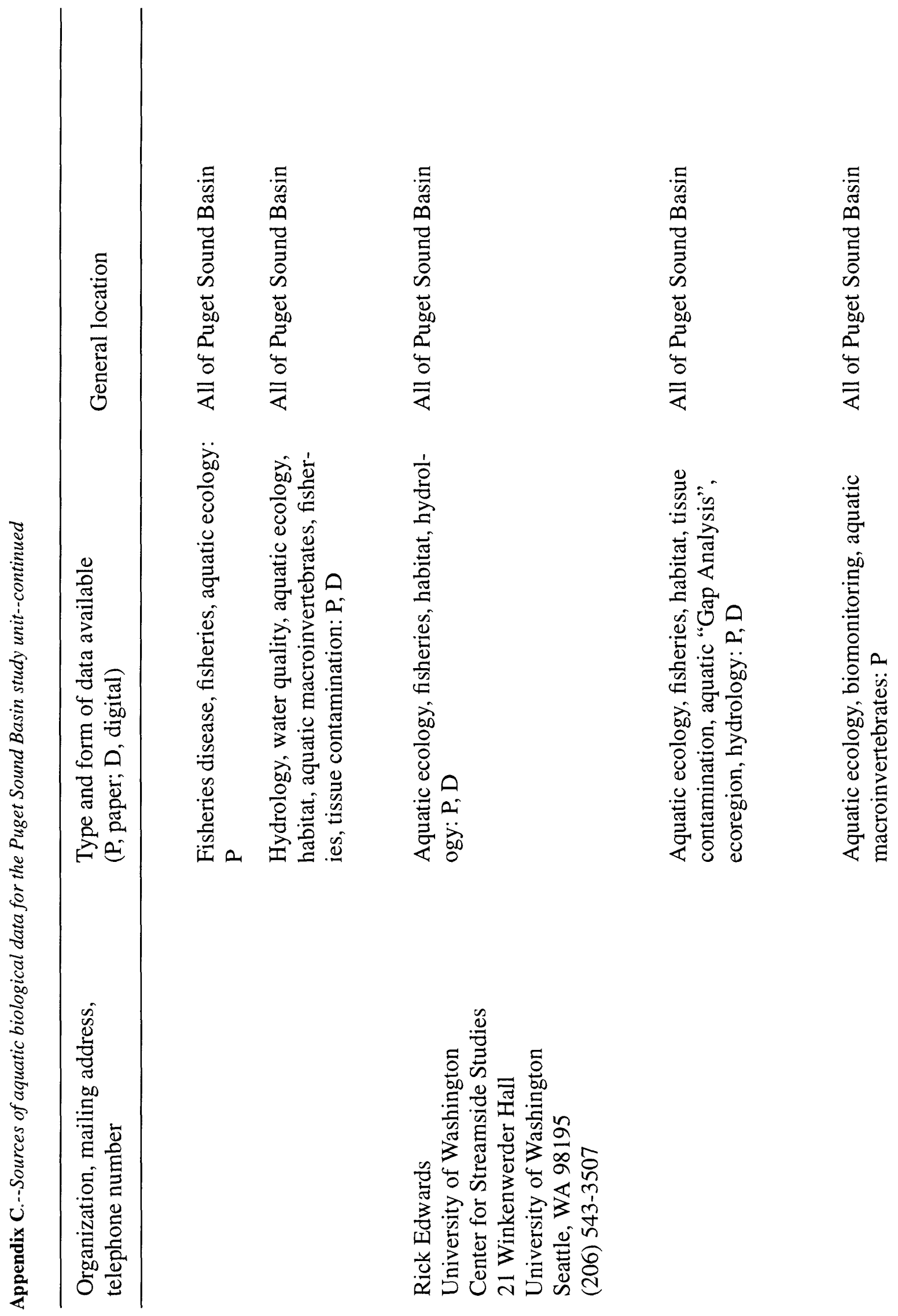




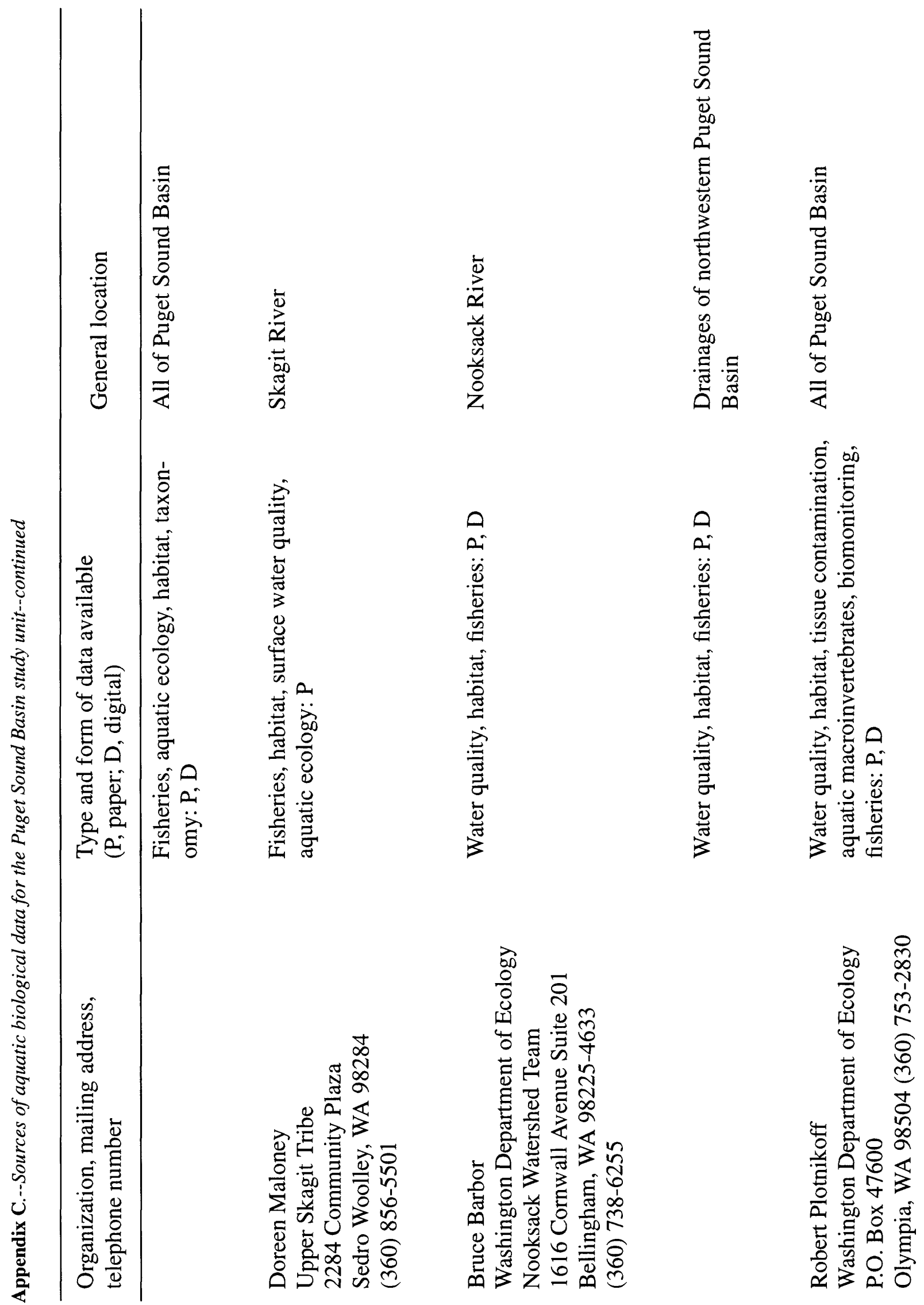




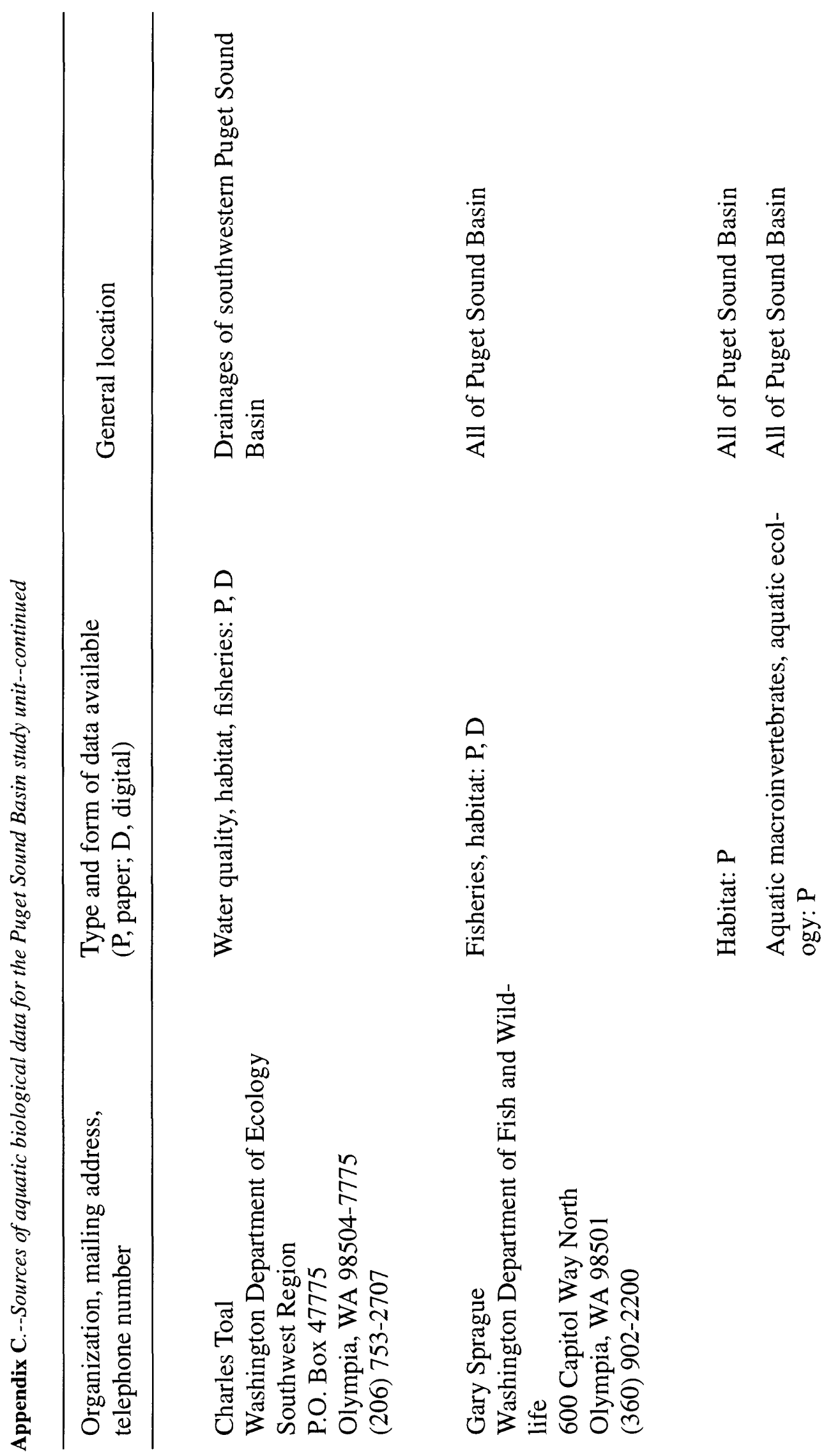




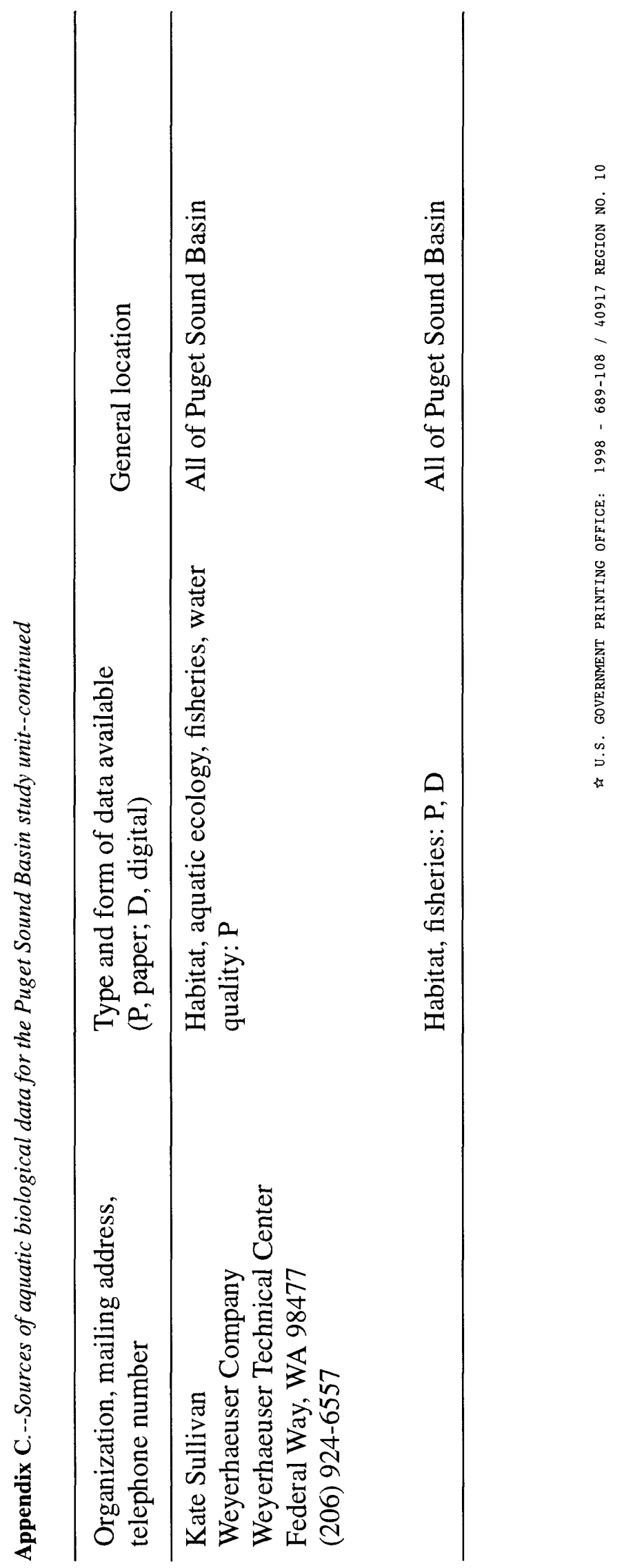

